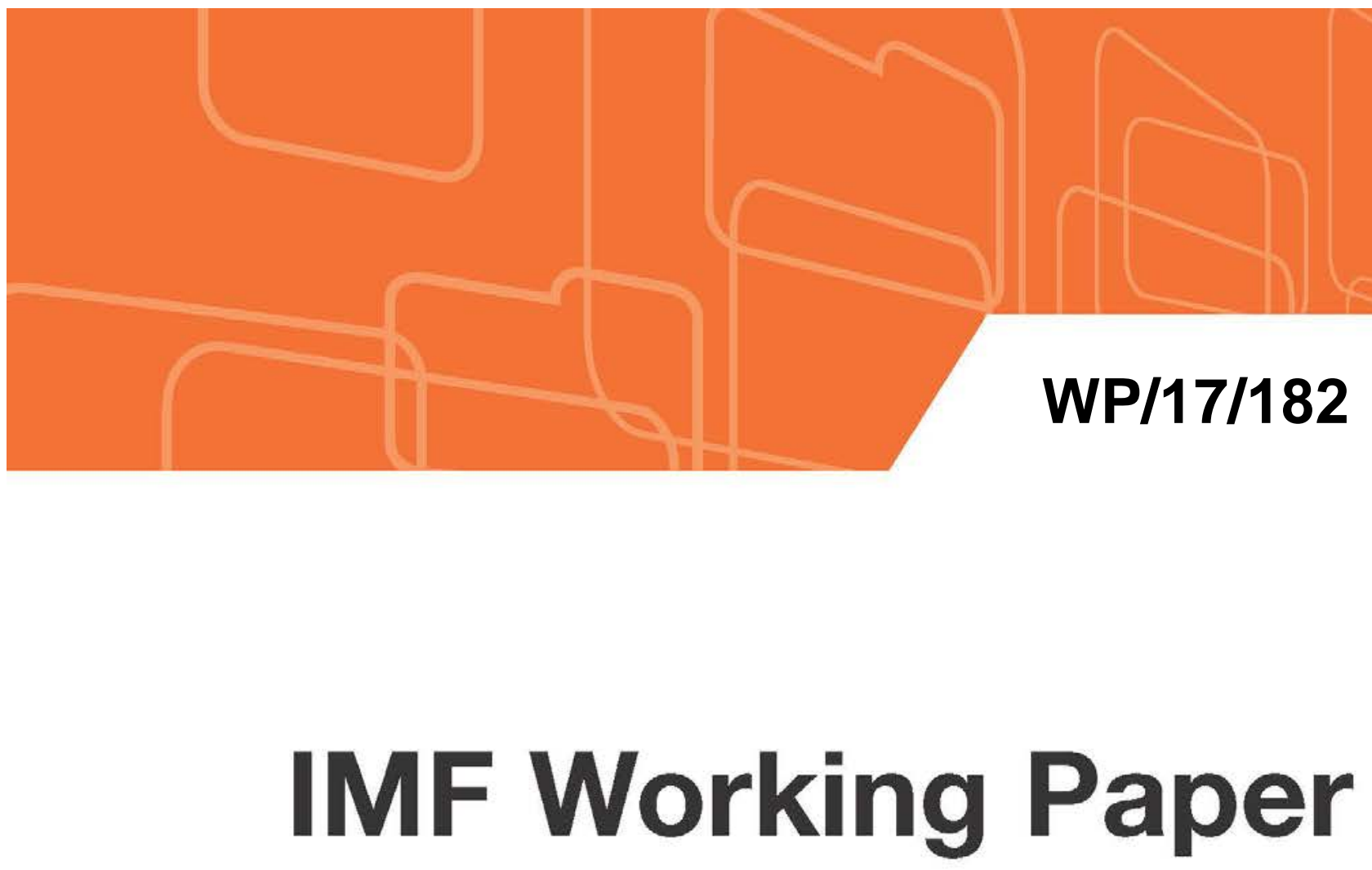

\title{
Structural Reforms and External Rebalancing
}

by Alexander Culiuc and Annette Kyobe

IMF Working Papers describe research in progress by the author(s) and are published to elicit comments and to encourage debate. The views expressed in IMF Working Papers are those of the author(s) and do not necessarily represent the views of the IMF, its Executive Board, or IMF management.

$$
\text { I N T E R N A T I O N A L M O N E T A R Y F U N D }
$$




\title{
IMF Working Paper
}

Strategy and Policy Review Department

\section{Structural Reforms and External Rebalancing ${ }^{1}$}

Prepared by Alexander Culiuc and Annette Kyobe

Authorized for distribution by Petya Koeva Brooks

August 2017

\section{IMF Working Papers describe research in progress by the author(s) and are published to elicit comments and to encourage debate. The views expressed in IMF Working Papers are those of the author(s) and do not necessarily represent the views of the IMF, its Executive Board, or IMF management.}

\begin{abstract}
Empirical research on structural reforms has focused primarily on their impact on growth and productivity. Yet an often-invoked rationale for structural reforms is their impact on external adjustment. This paper finds little evidence that structural reforms improve the current account in the short run, but they can increase the responsiveness and resilience of the economy to external shocks. In particular, elasticities of exports with respect to the real effective exchange rate increase with some structural indicators, suggesting that structural reforms facilitate the reallocation of resources to the tradable sector in response to a negative external shock. The paper concludes that structural reforms, while not having an immediate positive impact on the current account balance, can be an important complement to traditional macroeconomic adjustment.
\end{abstract}

JEL Classification Numbers: F14, F16, F32, F41, J68, O19

Keywords: structural reforms, current account, exports, REER, real exchange rate Authors’ E-Mail Addresses: aculiuc@imf.org, akyobe@imf.org

\footnotetext{
${ }^{1}$ We would like to thank Chad Steinberg for initiating and guiding this work, Petya Koeva Brooks and Sanjaya Panth for overseeing this project, Luis Cubeddu and Chris Papageorgiou for useful comments and suggestions.
} 


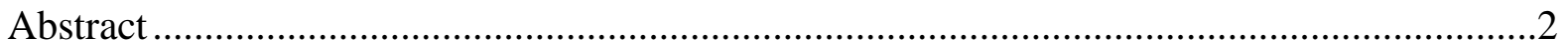

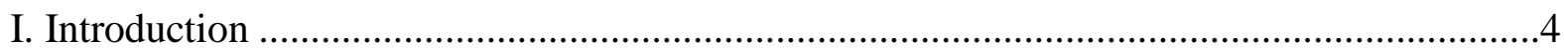

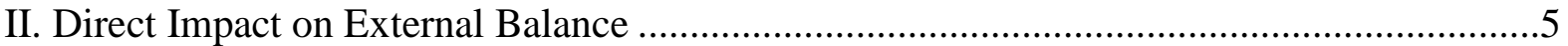

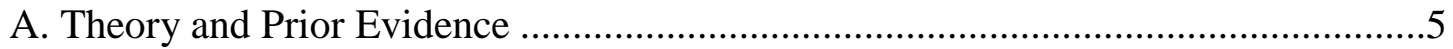

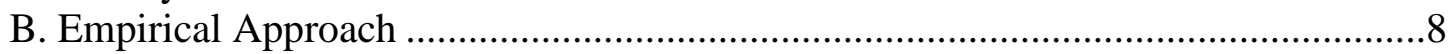

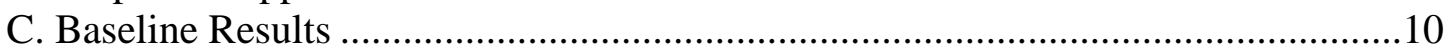

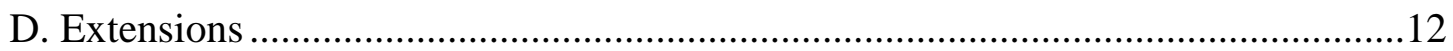

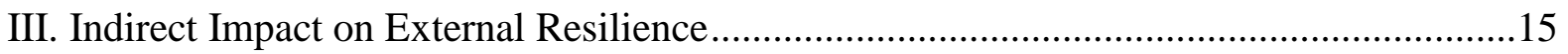

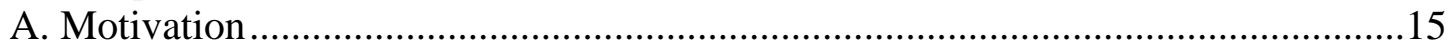

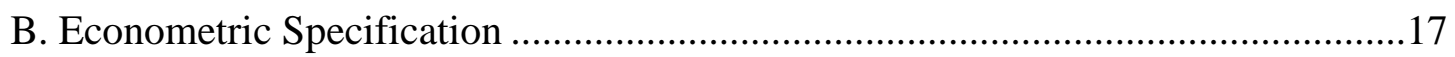

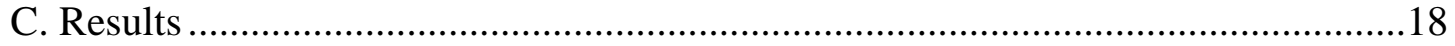

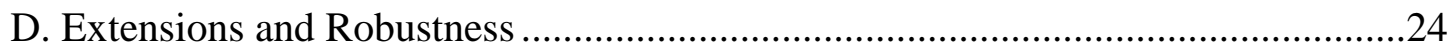

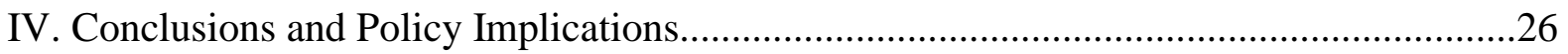

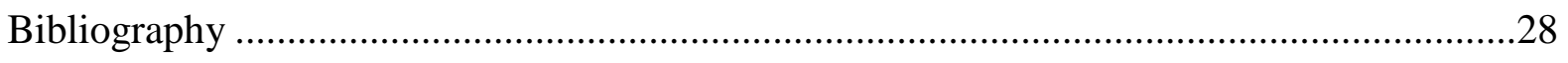

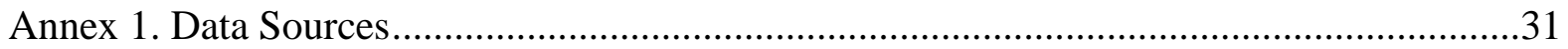

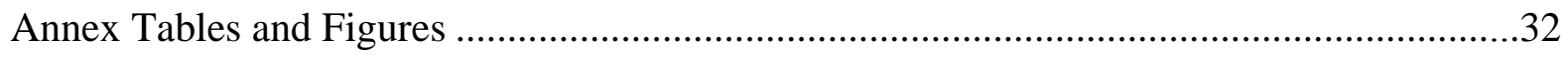

\section{Figures}

1. Export and REER Developments in Euro Area Periphery Countries.................................16

2. Linear vs. Percentile Presentation of Marginal Effects .................................................21

3. Marginal Effects for Securities Markets ..................................................................22

4. Highlights of Main Results ......................................................................................22

\section{Tables}

1. Direct Impact on the Current Account: Summary of Main Results....................................11

2. Effect of Reform on the Current Account, Large Reform Episodes...................................13

3. Effect of Reform on the Current Account, Accounting for Economic Cycle......................14

4. Effect of Reform on the Current Account, Accounting for High Commodity Shares in

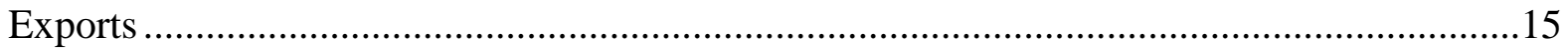

5. Benchmark Regressions for Manufacturing Exports .....................................................19

6. Manufacturing Exports Fixed Effects Regressions for Advanced Economies....................20

7. Indirect Impact: Summary of Main Results...............................................................23 


\section{INTRODUCTION}

Research on structural reforms has focused primarily on their impact on growth and productivity. Yet an often-invoked rationale for structural reforms is their impact on external adjustment. The empirical literature on this subject is limited and has focused on the impact of structural reforms on external balances in OECD countries. We fill this gap by studying the link between structural reforms and current account adjustments in a broader set of countries. This is an important issue from a policy perspective, as it informs thinking about the impact of structural reforms on external balance and stability, as well as macroeconomic projections.

We place our work in the context of three different strands of work. First, recent Fund efforts establish the importance - particularly in the absence of fiscal and monetary space - of reforms in increasing productivity and growth (IMF 2015a). Second, the latest Crisis Program Review (IMF 2015b) shows that internal devaluation through structural reforms (in programs with fixed exchange rates) proved difficult to achieve; even if devaluation did occur, it was not followed by a commensurate increase in exports. Lastly, Tressel et al. (2014) discuss the importance of structural reforms in supporting the reallocation of resources to the tradable sector, with the understanding that this would facilitate external adjustment.

There are two broad sets of arguments linking structural reforms and external balance. First, structural reforms can affect the steady state external balance, potentially by growing the tradable sector and ultimately improving the trade and current account balances. Second, structural reforms can affect the adjustment of the economy to a new steady state determined by some outside factors channeled, for example, through an exchange rate shock. We test empirically the following two hypotheses: (i) do structural reforms lead to improvements in external balance? and (ii) do structural reforms lead to more resilience to external shocks? We investigate these questions using cross-country panel regressions and a rich dataset of structural indicators spanning a variety of sources.

We find little evidence supporting the view that structural reforms improve the current account balance. This is broadly in line with the standard intertemporal open economy model, as well as related empirical work. The result remains unchanged across various reforms, as well as across countries in different income groups. However, we do find that structural reforms can affect the elasticity of exports with respect to the real exchange rate. This means that, when faced with an external shock, an economy with a better structural environment will see a faster pick up in the tradable sector. Overall, we conclude that, despite the lack of an immediate positive response on current account balances, structural reforms are an important ingredient to ensuring the resilience of the economy to external shocks. A normative assessment is beyond the scope of this paper, but it is worth emphasizing that a deterioration of the current account balance does not necessarily equate to a weaker external position. Some reforms may worsen the headline numbers of the current account, but these 
could also affect the current account norm ${ }^{2}$; hence, when measured against the norm, a country's external position could be stronger.

The rest of the paper is structured as follows. Section II analyzes the direct impact of structural reforms on the current account balance and its main components. Section III analyzes the indirect impact of structural reforms on export elasticities. These two sections present the relevant literature, lay out the empirical strategies, and discuss the results. Section IV concludes and discusses policy implications.

\section{DIRECT IMPACT ON EXTERNAL BALANCE}

\section{A. Theory and Prior Evidence}

The effect of structural policies on current account adjustment is theoretically ambiguous. Reforms can affect saving and investments of firms and households (thus trade flows) through a variety of channels. Indirectly, structural policies can impact the current account balance through increasing productivity. Reforms can also have a direct impact. For example, strengthening property rights reduces uncertainty, which should raise the investment rate, reduce precautionary savings, and worsen the current account balance. By increasing competition in the capital goods sector and lowering the price of investment goods, product market reforms can also boost investment (OECD, 2011).

The literature has used DSGE models to capture the complex reform interactions and dynamics. In a two country DSGE, Fournier and Koske (2010) find that the impact of a positive productivity shock on savings (and thus the current account) depends on several considerations - namely, consumers' preferences for consumption smoothing; if the rise in productivity and income is believed to be permanent or temporary; and whether the productivity shock is in the tradable or non-tradable sectors. Cacciatore et al. (2016) show in a DSGE set-up with micro-founded labor and product market frictions that unanticipated and permanent product market reforms generally deteriorate the current account balance, while labor market reforms tend to strengthen it. Testable hypotheses and theoretical considerations emerge from the literature that we take to the data.

Under our first hypothesis, productivity increases due to structural reform in the tradable sector will improve the current account balance. This is most easily derived from a static trade model, in which a productivity increase leads to an increase in tradable output and exports. Here, the current account may strengthen in the immediate aftermath of reforms if (i) consumers have a low propensity for inter-temporal consumption smoothing, so they postpone their consumption to benefit from lower prices in the future as productivity rises and/or (ii) reform increases productivity temporarily or agents perceive it as temporary or not

\footnotetext{
2 The "current account norm" is the CA balance that is consistent with economic fundamentals and desirable policies. See IMF (2017) for details.
} 
credible. In these instances, the current account balance strengthens temporarily as households save part of the higher income for the future. The same result is derived in Fournier and Koske (2010).

In our second hypothesis, productivity increases lead to a decline in the current account balance in the short-run but an increase over the long-run. The standard infinite horizon open economy model predicts that, following a productivity increase, consumption and investment will increase instantaneously, as agents are adjusting to the new equilibrium (a higher sum of discounted future incomes). Output, on the other hand, increases gradually, reflecting adjustment costs. The timing difference results in a current account deficit in the initial years following reform. Glick and Rogoff derive a theoretical model of the negative link between total factor productivity and the current account balance. A similar hypothesis is derived in Fournier and Koske (2010) in a two-sector model, which links increased productivity in the tradable sector to higher consumption (and therefore worsening external balance). They identify that the standard consumption smoothing channel (consume more today in response to expected higher income tomorrow) is supplemented by frontloading consumption on the expectation of a rising relative price of non-tradable goods on the account of the Balassa-Samuelson effect. ${ }^{3}$

The overall impact of structural reforms on the current account balance therefore depends on the speed at which consumption adjusts to a higher permanent income and the speed of factor mobility. The current account balance will improve the slower consumption responds to income and the faster factors move to the tradable sector. Other factors affecting the sign and magnitude of the impact of reforms on the current account balance relate to the characteristics of the reform shock, e.g., permanent versus temporary, anticipated versus unanticipated, affecting supply in the short term versus only the longer term.

There are further complexities in the relationship between structural policies and the current account balance that depend on country-specific circumstances. Structural policies can interact with other policies, macroeconomic conditions (output gap), or features of the economy (structure of the export basket) to influence the S-I behavior of firms and households. Wealth effects on saving could be larger in countries with more developed financial markets (Boone et al., 2001). And while structural reforms contribute to reducing CA imbalances in countries running surpluses, their potential to reduce imbalances in deficit countries is found to be more limited (IMF, 2012). Ultimately, the impact of structural reforms on the current account is an empirical question.

The empirical literature finds that structural reforms have a positive impact on productivity and growth (IMF 2008 and 2016, OECD 2008 and 2012, Bouis et al. 2016). Importantly, the

\footnotetext{
${ }^{3}$ If, however, reforms boost productivity in the non-tradable sector, the direction of the short-run current account reaction is ambiguous. It depends on consumers' preferences for intra-temporal (composition of the consumption basket stable) vs. inter-temporal (overall consumption stable) consumption smoothing.
} 
payoff from reforms varies across income group (IMF 2015b), how far a country is from the technology frontier (IMF2013), as well as institutional quality (IMF 2008).

In turn, productivity shocks have been identified - since the seminal work of Glick and Rogoff (1995) — as one of the driving forces behind current account movements. In their framework, country-specific productivity shocks negatively affect the current account balance, while global productivity shocks do not have any significant impact. Overall, the inter-temporal model is shown to perform well if confronted with the data. Since then, several empirical papers have confirmed the validity of the Glick and Rogoff results and studied the incidence of productivity shocks on the current account in an open economy. ${ }^{4}$ More recently, Bussière, Fratzscher and Müller (2005) investigate the role of productivity shocks compared to budget deficits in determining current account balances in 21 OECD countries from 1960 to 2003. They find no evidence of a contemporaneous effect of budget deficits, while productivity shocks appear to play an important role.

Empirical work on the direct impact of reform on the current account is limited, and few studies find a robust link. Using pooled time series (controlling for cyclical factors), Kennedy and Sløk (2005) find that while product and financial market reforms exhibit a significant negative relationship with the current account, their contribution to explaining current account positions is limited.

Jaumotte and Sodsriwiboon (2010) focus on the impact of labor market indicators (minimum wages, unemployment benefits and employment protection legislation). They find that higher minimum wages lower the current account balance, presumably by raising wage costs and reducing competitiveness. Other indicators are insignificant.

Cheung et al. (2010) and IMF (2012) ${ }^{5}$ find that institutional quality negatively impacts current account balances. This negative relationship can be interpreted in several ways. For some it may reflect capital flowing from emerging economies towards countries perceived to possess more efficient institutions. Or it may be that improved institutions lower the need for precautionary savings, reducing current account balances. Kerdrain, Koske and Wanner (2010) disentangle the transmission channels and investigate separate impacts on savings and investment. They find that (i) product market liberalization boosts investment and weakens the current account balance; (ii) financial market deregulation lowers savings; (iii) stricter employment protection is associated with lower saving rates if unemployment benefits are low.

\footnotetext{
${ }^{4}$ Hoffman (2001), Nason and Rogers (1999), Gregory and Head (1999).

${ }^{5}$ Regulatory quality captures a wide set of structural indicators including: price controls, competitive environment, trade barriers, labor and product market liberalization, regulatory burdens, ownership restrictions, investment climate, legal regulation, and tax effectiveness.
} 


\section{B. Empirical Approach}

We estimate the impact of structural reform on the current account using a sample of 108 countries from 1970 to 2011; data sources are detailed in Annex 1. The focus is mainly on structural policies that affect domestic settings but also include policies that directly affect capital flows (e.g., removal of restrictions on trade and foreign direct investment). As discussed in the previous section, interpreting the estimated coefficient of the structural indicator on the current account is challenging. We proceed by disentangling the impact and looking separately at import and export equations. ${ }^{6}$

We use Jordà (2005) local projection (LP) technique to estimate current account, import, and export impacts of structural reforms dynamically for up to 5 years after the reform occurred. This specification allows us to capture year-by-year impacts in the event reforms have a Jcurve effect on the current account balance. For example, the initial deterioration due to higher imports of capital goods in response to the productivity can be followed by an improvement as exports gradually increase on the back of higher productivity and investment. Aside from tracking such dynamics over time, LP is flexible in accommodating nonlinear impacts. Here, we investigate if reform effects differ depending on the structure of the export basket, i.e., if a country is a commodity exporter. The LP technique also allows to control for endogeneity of the the reform variable by including crises and controlling for several time-varying and time-invariant factors including country-fixed effects. However, including crises may not be enough. Countries could share other characteristics beyond the occurrence of crises that also determine current account changes. For example, countries with more efficient governments may be less likely to adopt reforms and yet achieve external adjustment if needed.

Reform shocks are identified using structural variables (described in Annex 1). An improvement in the variable is assumed to signal a "reform" which depending on the magnitude of the change can be small or large. The reform shock is derived as the year-onyear change in reform indicator (if it is positive) and takes the value 0 if no reform was identified. We estimate the impact of the reform shock on the current account, imports, and exports in the next five years using impulse response functions. The following cross-country time series equation is estimated for each of the five years $h=1 \ldots .5$ after the reform shock has occurred:

$$
y_{i, t+h}=\beta_{h} R_{i, t}+\mu_{h}(L) y_{i, t+h-1}+X_{i, t-1}^{\prime} \varphi_{h}+u_{i}+\lambda_{t}+\epsilon_{i, t+h}
$$

where $y_{i, t+h}=Y_{i, t+h}-Y_{i, t-1}$, and $Y_{i t}$ is the current account in country $i$ observed at year $t$. We estimate the model at each horizon $h=0,1, \ldots 5$. The approach estimates a set of five

\footnotetext{
${ }^{6}$ An alternative would be to look at savings and investment separately. As our sample of interest includes low income countries we use an approach that has the least data limitations. Also, focusing on exports provides a link to the second section where we analyze the role reforms can help play in helping an economy adjust to shocks through increasing export elasticities.
} 
independent equations. $R_{i, t-1}$ is a shock across each reform indicator or institutional variable. The estimated $\beta_{h}$ coefficients give the impact at horizon $h$ and capture short and mediumterm impacts of reforms on three dependent variables: the current account, exports and imports in percent of GDP. Current account balances are the outcome of general equilibrium processes and depend not only on domestic economic conditions but also on conditions abroad. For simplicity, our analysis assumes no reforms take place in the rest of the world or at least that any such reforms have smaller effects than those at home. We only include trade flows and exclude the income account.

The equation includes lags of the dependent variable to control for persistence and a set of controls for the cycle $X_{i t}$, growth in domestic and foreign demand and terms of trade. ${ }^{7}$ Control variables are lagged one year to minimize endogeneity concerns. Five lags of crisis dummies, taking the value one if the country experienced a banking or currency crisis, or a recession are included. Economic crises can affect the dependent variables (e.g., current account adjustment through import compression) while being correlated with the probability of observing a reform shock. Hence, not controlling for them could introduce an omitted variable bias (Duval 2008). The model includes country fixed effects to account for unobserved time-invariant factors (i.e., cross-country heterogeneity such as differences in institutions) as well as time fixed effects, to account for unobserved global shocks and country-specific time trends. Country fixed effects may dampen the estimated link between slow-changing structural indicators and the current account balance.

Standard errors are clustered by country. The specification is estimated over the total sample rather than by income group. Our prior, confirmed in robustness tests, is that the impact of reform does not vary directionally across countries by income group. Furthermore, we do not always have sufficient reform shocks in each group to look for differential impacts in a dynamic specification. In this exercise, we leave the REER out of from the estimated equation, as the REER is not an exogenous driver of the current account. Some reforms could affect the current account through the REER, or might affect the REER at the same time as the current account, with the risk that the coefficient on structural variables becomes insignificant. In an economy starting at full employment, a reform shock that shifts consumption on a sustained basis will first directly affect the CA and output — but such a shock will also induce macroeconomic adjustment involving changes in relative prices, including the REER.

This analysis has shortcomings that cannot be overcome. First, it captures an average effect across heterogeneous reform experiences, which reduces chances of obtaining significant and

\footnotetext{
${ }^{7}$ We include a complete set of controls from the IMF's External Balance Assessment analytical toolkit as robustness. These are averages of log GDP per capita, previous period growth, fiscal balance to GDP, net foreign assets to GDP, old (young) age dependency ratios and trade openness. Explanatory variables are converted into deviations from a GDP-weighted cross-country average to emphasize that current accounts are influenced also by foreign economic conditions.
} 
robust results. Second, structural policies are likely to influence saving and investment decisions through changes in the macroeconomic control variables, reducing the chances of finding significant coefficients on the policy variables themselves. Third, IMF's surveillance on select countries has found that changes in structural indicators do not always neatly map to known reform episodes, and vice-versa. Finally, countries usually do not embark on a single reform -instead, reforms are usually implemented as part of a package. Given that we look at one reform at a time, reform impacts could be underestimated. However, the last two points are not specific to our findings.

\section{Baseline Results}

Evidence of a positive impact of structural reforms on current account balances is limited. Rather, results support the hypothesis that in the short-run, most reforms-financial, trade openness, institutions, product market, labor and higher R\&D spending-have no impact. (The results are summarized in Table 1 , and detailed results are presented in Table A1-Table A3). If anything, some reforms - banking sector, business regulations and improvements in legal system - are associated with a deterioration of the current account balance in the shortterm as imports and possibly investment respond to higher levels of productivity. In the medium-term, exports do respond to large reform episodes. Though capturing a positive impact on the current account balance remains elusive for most reforms-except for reform of securities market, product market reform in the telecom sector, and higher research and development spending. Controls for the relative cyclical position are significant. In the current account equation, higher GDP growth relative to trading partners comes in significant. In the exports equation, partner growth increases exports while domestic demand growth significantly predicts import growth.

Labor markets: The sign on lower collective bargaining power suggests a positive link with the current account balance, though the estimated coefficient is not significant.

Product markets: Indicators of product market regulation are significant in the current account and export specifications. In the short-run, a better regulated business environment weakens the current account and increases imports. Deregulating product markets leads to increasing entry into domestic markets including foreign competitors. This should weaken the current account, in part through increased capital inflows before equilibrating mechanisms gradually set in. Indeed, in the medium-term less regulation of networks improves the current account balance; in particular, deregulating telecom and electricity markets increases the current account balance two to three years after the reforms are implemented. This result is mirrored in an increase in non-commodity exports, which gets increasingly larger over the medium-term projection horizon (years 2, 3, 4). 
Table 1. Direct Impact on the Current Account: Summary of Main Results

\begin{tabular}{|c|c|c|c|c|c|}
\hline & Year 1 & Year 2 & Year 3 & Year 4 & Year 5 \\
\hline \multicolumn{6}{|l|}{ Financial sector } \\
\hline Banking & $-{ }^{\star \star}$ & - & - & - & + \\
\hline Interest rate controls & - & - & $-{ }^{*}$ & $-{ }^{*}$ & - \\
\hline Directed credit/reserve requirements & - & - & - & - & + \\
\hline Privatization & - & + & + & + & + \\
\hline Banking Supervision & - & + & - & + & + \\
\hline Security Markets & + & $+* *$ & $+* *$ & $+* \star *$ & $+* *$ \\
\hline \multicolumn{6}{|l|}{ Openness } \\
\hline Mean tariff rate & - & $-{ }^{*}$ & $--^{* * *}$ & $-{ }^{* \star}$ & $-{ }^{* *}$ \\
\hline Regulatory trade barriers & - & - & + & - & - \\
\hline Restrictions on current account transactions & + & + & + & - & - \\
\hline Capital flows restrictions & $-^{*}$ & + & + & - & - \\
\hline \multicolumn{6}{|l|}{ Institutions } \\
\hline Legal System \& Property Rights & $-{ }^{*}$ & $-{ }^{\star \star}$ & - & - & - \\
\hline Protection of property rights & - & - & + & - & - \\
\hline \multicolumn{6}{|l|}{ Product market regulation } \\
\hline Business regulations & $-^{*}$ & - & - & - & - \\
\hline Product: telecom and electricity & - & $+* *$ & + & $+{ }^{*}$ & + \\
\hline Product: telecom & + & $+* \star$ & $+* *$ & + & $-{ }^{*}$ \\
\hline Product: electricity & - & + & + & + & $+^{*}$ \\
\hline \multicolumn{6}{|l|}{ Infrastructure } \\
\hline Electricity production capacity & + & + & + & + & - \\
\hline Telephone lines & - & - & - & - & - \\
\hline Roads density & - & - & + & + & - \\
\hline \multicolumn{6}{|l|}{ Labor } \\
\hline Hiring and firing regulations & - & - & - & - & - \\
\hline Centralized collective bargaining & - & + & + & + & + \\
\hline \multicolumn{6}{|l|}{ R\&D } \\
\hline Basic $R \& D$ spending & + & + & + & $+*$ & $+* *$ \\
\hline
\end{tabular}

Note: Table shows the sign on the lagged structural indicator. ${ }^{*}, * *, * * *$ indicate that coefficients are significant at 10,5 and 1 percent levels respectively. All regressions inlcude country and time fixed effects and cluster standard errors on country.

Infrastructure: Improvements in infrastructure have no significant impact on the current account. Increasing electricity production capacity, however, does increase non-commodity exports starting in the second year, with gains plateauing by the fourth year.

Institutions: Improvements in the institutional environment, specifically in the legal system and property rights, are associated with a weaker current account balance in the short-term. This may be due to a safer institutional environment both raising investment (including investment related imports) and lowering incentives for precautionary savings. This result is in line with EBA findings, where an improvement in the institutional environment is associated with a weakening of the current account (IMF 2012, Annex 4). 
Financial sector: Deregulating domestic financial and capital markets can stimulate the entry of foreign capital with associated upward pressures on the exchange rate, downward pressures on the interest rate, and a weakening current account. In our data, banking sector reform is associated with a deterioration in the current account balance one year after implementation. In particular, reducing interest rate controls (which should lead to upward pressure on the exchange rate) deteriorates the current account over the medium term. This impact is reflected in an increase in imports (and a decrease in exports) throughout most of the projection horizon. If imports are investment goods, higher capital accumulation could lead to better productivity and competitiveness, which would strengthen the current account in the medium to long-term. This effect, however, is not observed over the medium-term. Securities market development improves the current account after two years, with effects increasing in outer years. This result is somewhat counterintuitive, as a more developed securities market could be expected to attract capital inflows and therefore deteriorate the current account balance.

Openness: Trade reform and capital account liberalization do not improve the current account balance. The link between capital account liberalization and the current account is not straightforward as effects work through both trade and financial flows. In theory, lowering capital flow restrictions should lead to stronger net inflows and an appreciating exchange rate that would weaken, all else equal, the current account. Lowering capital account restrictions on non-residents deteriorates the current account in the short and increasingly in the medium-term, with the impact through the financial account. As expected, lifting restrictions on FDI increases imports. Lowering trade barriers, specifically decreasing import tariffs deteriorates the current account. The mechanism works through an increase in imports which negatively impacts the current account in the short and medium-term.

The next section investigates several extensions relating to large reform episodes, phase of economic cycle, and export basket composition.

\section{Extensions}

\section{Large Reform Episodes}

In the first extension, we estimate the impact of only large reform episodes on external adjustment. Large reform episodes are better identified, given the difficulties involved in measuring incremental reforms based on small changes in available policy indicators. In addition, focusing on large episodes allows us to treat them as a shock and estimate impulse response functions using a dynamic specification. We identify a large reform episode as changes in reforms that are larger than two standard deviations. The episode takes the value 1 , if the calculated as the year-on-year change in the reform index is larger than two standard deviations and zero otherwise. 
We find that even large reform episodes are not associated with changes in the current account balance. However, we do find that that that large reforms - in particular product market regulation (in energy, transport and communication and the policy environment for investment), capital controls, and labor markets are associated with a positive impact on exports.

Table 2. Effect of Reform on the Current Account, Large Reform Episodes

\begin{tabular}{|c|c|c|c|c|c|c|c|c|c|c|c|c|c|c|c|}
\hline & \multicolumn{5}{|c|}{ Current account to GDP } & \multicolumn{5}{|c|}{ Non-commodity exports to GDP } & \multicolumn{5}{|c|}{ Imports to GDP } \\
\hline & (Y1) & (Y2) & $(\mathrm{Y} 3)$ & (Y4) & (Y5) & $(\mathrm{Y} 1)$ & $(\mathrm{Y} 2)$ & $(\mathrm{Y} 3)$ & (Y4) & (Y5) & (Y1) & $(\mathrm{Y} 2)$ & $(\mathrm{Y} 3)$ & $(\mathrm{Y} 4)$ & (Y5) \\
\hline \multicolumn{16}{|l|}{ Trade reform } \\
\hline Number of tariffs & $\begin{array}{r}-3.902^{* *} \\
(1.375)\end{array}$ & $\begin{array}{r}-4.074^{\star} \\
(2.149)\end{array}$ & $\begin{array}{l}-4.528^{*} \\
(2.367)\end{array}$ & $\begin{array}{l}-2.697 \\
(2.311)\end{array}$ & $\begin{array}{l}-1.014 \\
(2.159)\end{array}$ & $\begin{array}{c}0.512 \\
(1.087)\end{array}$ & $\begin{array}{c}1.735 \\
(1.163)\end{array}$ & $\begin{array}{c}1.248 \\
(1.422)\end{array}$ & $\begin{array}{c}2.43 \\
(1.813)\end{array}$ & $\begin{array}{c}1.135 \\
(1.642)\end{array}$ & $\begin{array}{l}4.021^{\text {** }} \\
(1.946)\end{array}$ & $\begin{array}{l}4.711^{\text {** }} \\
(2.354)\end{array}$ & $\begin{array}{c}3.27 \\
(3.670)\end{array}$ & $\begin{array}{c}3.931 \\
(2.643)\end{array}$ & $\begin{array}{c}3.915 \\
(2.570)\end{array}$ \\
\hline Capital account restrictions (Quinn-Ito) & $\begin{array}{l}-3.52^{\star *} \\
(1.117)\end{array}$ & $\begin{array}{l}-4.376 \\
(2.936)\end{array}$ & $\begin{array}{l}-1.275 \\
(2.594)\end{array}$ & $\begin{array}{l}-2.523 \\
(2.608)\end{array}$ & $\begin{array}{c}0.731 \\
(2.682)\end{array}$ & $\begin{array}{c}0.883 \\
(1.607)\end{array}$ & $\begin{array}{l}2.987^{*} \\
(1.579)\end{array}$ & $\begin{array}{l}4.935^{\star} \\
(2.314)\end{array}$ & $\begin{array}{l}6.234^{* *} \\
(2.302)\end{array}$ & $\begin{array}{l}6.629 * * * \\
(2.147)\end{array}$ & $\begin{array}{c}-0.9 \\
(2.901)\end{array}$ & $\begin{array}{c}1.279 \\
(2.806)\end{array}$ & $\begin{array}{c}6.358 \\
(6.823)\end{array}$ & $\begin{array}{c}4.851 \\
(3.294)\end{array}$ & $\begin{array}{c}5.23 \\
(3.198)\end{array}$ \\
\hline \multicolumn{16}{|l|}{ Product market } \\
\hline Regulation in energy, transport $\&$ com. & $\begin{array}{l}-0.198 \\
(0.441)\end{array}$ & $\begin{array}{l}-0.017 \\
(0.582)\end{array}$ & $\begin{array}{r}-0.569 \\
(0.637)\end{array}$ & $\begin{array}{l}-0.343 \\
(0.718)\end{array}$ & $\begin{array}{c}0.221 \\
(0.727)\end{array}$ & $\begin{array}{c}0.616^{*} \\
(0.370)\end{array}$ & $\begin{array}{c}1.079^{*} \\
(0.553)\end{array}$ & $\begin{array}{c}0.712 \\
(0.681)\end{array}$ & $\begin{array}{c}0.487 \\
(0.773)\end{array}$ & $\begin{array}{c}0.648 \\
(0.836)\end{array}$ & 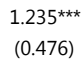 & $\begin{array}{c}2.032^{* \star} \\
(0.680)\end{array}$ & $\begin{array}{r}1.976 \text { ** } \\
(0.780)\end{array}$ & $\begin{array}{c}1.381 \\
(0.860)\end{array}$ & $\begin{array}{c}0.984 \\
(0.907)\end{array}$ \\
\hline Policy environment for foreign investment & $\begin{array}{c}1.867 \\
(1.138)\end{array}$ & $\begin{array}{c}0.303 \\
(1.552)\end{array}$ & $\begin{array}{l}-1.393 \\
(1.450)\end{array}$ & $\begin{array}{l}-0.274 \\
(1.493)\end{array}$ & $\begin{array}{c}0.095 \\
(1.464)\end{array}$ & $\begin{array}{l}1.430^{* *} \\
(0.623)\end{array}$ & $\begin{array}{l}1.436^{*} \\
(0.818)\end{array}$ & $\begin{array}{l}2.112^{\star \star} \\
(0.965)\end{array}$ & $\begin{array}{c}1.151 \\
(1.054)\end{array}$ & $\begin{array}{c}1.591 \\
(1.131)\end{array}$ & $\begin{array}{c}0.016 \\
(1.301)\end{array}$ & $\begin{array}{c}1.902 \\
(1.544)\end{array}$ & $\begin{array}{l}3.991^{* *} \\
(1.770)\end{array}$ & $\begin{array}{c}3.159^{*} \\
(1.861)\end{array}$ & $\begin{array}{c}2.461 \\
(1.913)\end{array}$ \\
\hline \multicolumn{16}{|l|}{ Labor market reform } \\
\hline Collective bargaining & $\begin{array}{c}0.258 \\
(0.624)\end{array}$ & $\begin{array}{c}0.163 \\
(0.764)\end{array}$ & $\begin{array}{l}-0.044 \\
(0.833)\end{array}$ & $\begin{array}{l}-0.519 \\
(0.817)\end{array}$ & $\begin{array}{l}-0.129 \\
(0.804)\end{array}$ & $\begin{array}{c}1.638 \\
(0.508)\end{array}$ & $\begin{array}{c}1.866 \\
(0.723)\end{array}$ & $\begin{array}{c}2.336 \\
(0.867)\end{array}$ & $\begin{array}{c}1.790 \\
(0.997)\end{array}$ & $\begin{array}{c}1.172 \\
(1.123)\end{array}$ & $\begin{array}{c}0.789 \\
(0.707)\end{array}$ & $\begin{array}{c}1.082 \\
(0.931)\end{array}$ & $\begin{array}{c}0.683 \\
(1.052)\end{array}$ & $\begin{array}{c}1.126 \\
(1.120)\end{array}$ & $\begin{array}{c}0.647 \\
(1.140)\end{array}$ \\
\hline
\end{tabular}

Note: The table shows regressions of the change in the current account, non-commodity exports and imports in percent of GDP on dummies for large reform episodes for year 1(Y1) through 5 (Y5). Standard errors in parentheses are robust and clustered by country. *, **, *** indicate that coefficients are significant at 10, 5 and 1 percent levels respectively.

\section{Reform Interactions}

In the second and third extensions, we test the interaction between reforms and the current account, conditional on (i) business cycle phase at the time of reforms and (ii) commodity exporter status of the country. The effects of reforms may be affected by the state of the cycle. Conditional on all remaining equal across countries, the path of the current account in the aftermath of reform implementation could be different in good times or in times of crisis. Similarly, the response of the current account—and especially exports — to reforms could depend on the structure of the export basket. An export basket dominated by commodities, and particularly fuel, may not be sensitive to reforms. As an example, oil export output may not dependent on local infrastructure if it has its own network of roads and port infrastructure.

We augment the baseline LP model to include these two different interactions. The state of the business cycle is captured by a dummy variable taking the value 1 whenever the output gap is lower than -0.5 percent of potential output, and 0 otherwise. Data for advanced and emerging markets are from the IMF's WEO database. The output gap for LICs is calculated as the deviation of actual output from trend GDP, computed using a standard HodrickPrescott filter. In our second test, we interact the share of commodities in total exports with our reform shock. The specification is as follows:

$y_{i, t+h}=\left(\beta_{1 h}+\beta_{2 h} I_{i, t}\right) R_{i, t}+\theta_{h} I_{i, t}+\mu_{h}(L) e_{i, t+h-1}+X_{i, t-1}^{\prime} \varphi_{h}+u_{i}+\lambda_{t}+\epsilon_{i, t+h}$ 
$I_{i, t}$ is a dummy variable capturing periods of economic slack and defined as follows:

$$
I_{i, t}=\mathbf{1}[\text { Output gap }<-0.5]
$$

The coefficients of interest are $\beta_{1 h}$ and $\left(\beta_{1 h}+\beta_{2 h}\right)$. They measure the association of reforms with cumulative changes in the current account, imports and exports to GDP at each horizon in good and bad times, respectively. The interaction with commodity dependence is specified in the same way, except we use a continuous variable (share in total exports) to avoid using arbitrary thresholds to label countries as commodity exporters. The model is again estimated using the LP method with corrected standard errors.

Table 3. Effect of Reform on the Current Account, Accounting for Economic Cycle Dependent variable: Deviation in current account relative to pre-reform year

\begin{tabular}{|c|c|c|c|c|c|}
\hline & Year 1 & Year 2 & Year 3 & Year 4 & Year 5 \\
\hline \multirow[t]{2}{*}{ Banking, no slack } & -3.657 & $-14.653^{*}$ & $-18.358^{\star \star}$ & $-14.698^{\star *}$ & $-16.362^{* * *}$ \\
\hline & $(0.568)$ & $(1.856)$ & $(2.453)$ & $(2.556)$ & (3.278) \\
\hline \multirow[t]{2}{*}{ Banking sector, slack } & 1.188 & 10.731 & $19.505^{\star \star}$ & $13.906^{*}$ & $18.921^{\star \star *}$ \\
\hline & $(0.151)$ & (1.148) & $(2.173)$ & $(1.722)$ & $(2.815)$ \\
\hline Observations & 364 & 364 & 364 & 364 & 364 \\
\hline Countries & 65 & 65 & 65 & 65 & 65 \\
\hline $\mathrm{R}^{2}$ & 0.169 & 0.208 & 0.318 & 0.311 & 0.274 \\
\hline \multirow[t]{2}{*}{ Business entry, slack } & 2.197 & $6.353^{\star \star}$ & $3.509^{* *}$ & $-4.847^{\star \star}$ & $6.446^{\star * \star}$ \\
\hline & $(0.954)$ & $(2.106)$ & (2.185) & (2.468) & $(3.043)$ \\
\hline Observations & 98 & 98 & 98 & 98 & 98 \\
\hline Countries & 48 & 48 & 48 & 48 & 48 \\
\hline$R^{2}$ & 0.917 & 0.944 & 0.967 & 0.918 & 0.918 \\
\hline \multirow[t]{2}{*}{ Telecom regulation, no slack } & 14.988 & $39.619 * * \star$ & $43.202^{\star \star \star}$ & $33.971^{\star \star \star}$ & $37.254^{\star \star}$ \\
\hline & $(1.259)$ & (3.154) & $(4.381)$ & $(4.472)$ & $(2.659)$ \\
\hline \multirow[t]{2}{*}{ Telecom regulation, slack } & -13.422 & $-37.317^{\star \star \star}$ & $-37.319 * \star \star$ & $-25.238^{\star \star \star}$ & $-31.887^{\star \star}$ \\
\hline & $(1.128)$ & $(2.976)$ & $(4.043)$ & $(3.416)$ & $(2.564)$ \\
\hline Observations & 100 & 100 & 100 & 100 & 100 \\
\hline Countries & 56 & 56 & 56 & 56 & 56 \\
\hline$R^{2}$ & 0.888 & 0.929 & 0.957 & 0.967 & 0.918 \\
\hline
\end{tabular}

Note: Standard errors in parentheses are robust and clustered by country. ${ }^{*}, * *, * * *$ indicate that coefficients are significant at 10, 5 and 1 percent levels respectively. All regressions inlcude country and time fixed effects.

Evidence on interaction effects is mixed. Table 3 shows that the impact of reforms in financial and product markets is affected by the cyclical position of the economy. More specifically, the effect of structural reforms (banking sector reform and lower entry barriers) launched during bad times is positive and statistically significant. In contrast, lower regulation of networks (telecom, in particular) deteriorates the current account in periods of slack, with the result possibly driven by lower exports which are also seen to worsen. Results on the interaction with the share of commodity exports are similarly weak, with only interactions on banking sector reform and network reforms significant (Table 4). Here, the 
higher the share of commodity exports is associated with larger deteriorations in the current account from reforms. ${ }^{8}$

Table 4. Effect of Reform on the Current Account, Accounting for High Commodity Shares in Exports Dependent variable: Deviation in current account relative to pre-reform year

\begin{tabular}{lccccc}
\hline & Year 1 & Year 2 & Year 3 & Year 4 & Year 5 \\
\hline Banking & 2.277 & 5.847 & 4.202 & $-8.749^{*}$ & 1.882 \\
& $(0.667)$ & $(1.288)$ & $(0.868)$ & $(1.672)$ & $(0.450)$ \\
Banking (high commodity share) & -18.512 & $-46.907^{\star * *}$ & $-42.494^{\star *}$ & 2.474 & $-28.845^{\star * \star}$ \\
& $(1.442)$ & $(2.814)$ & $(2.457)$ & $(0.168)$ & $(2.828)$ \\
Observations & 426 & 426 & 426 & 426 & 426 \\
Countries & 81 & 81 & 81 & 81 & 81 \\
$\mathrm{R}^{2}$ & 0.219 & 0.287 & 0.358 & 0.330 & 0.340 \\
\hline \multirow{2}{*}{ Legal system and property rights } & & & & & \\
& $-3.809^{*}$ & $-4.801^{*}$ & $-4.596^{*}$ & -4.255 & $-4.896^{*}$ \\
Legal system and property rights (high comn & $(1.684)$ & $(1.837)$ & $(1.732)$ & $(1.584)$ & $(1.665)$ \\
& 11.880 & 12.655 & 10.366 & 9.181 & 12.790 \\
Observations & $(1.316)$ & $(1.231)$ & $(0.985)$ & $(0.895)$ & $(1.202)$ \\
Countries & 1,295 & 1,295 & 1,295 & 1,294 & 1,293 \\
$\mathrm{R}^{2}$ & 106 & 106 & 106 & 106 & 106 \\
\hline Business regulation & 0.563 & 0.550 & 0.517 & 0.489 & 0.506 \\
\hline Business regulation (high commodity share) & 3.643 & 6.022 & 5.466 & 8.362 & 11.686 \\
& $(0.683)$ & $(0.825)$ & $(0.609)$ & $(0.953)$ & $(1.251)$ \\
Observations & 468 & 468 & 467 & 466 & 466 \\
$\mathrm{R}^{2}$ & 92 & 92 & 92 & 91 & 91 \\
\hline
\end{tabular}

Note: Standard errors in parentheses are robust and clustered by country. $*, * *, * * *$ indicate that coefficients are significant at 10, 5 and 1 percent levels respectively. All regressions inlcude country and time fixed effects.

\section{INDIRECT IMPACT ON EXTERNAL RESILIENCE}

\section{A. Motivation}

Expenditure-switching policies - achieved through a correction in the real exchange rate are a key ingredient of macroeconomic adjustment programs. A real devaluation, whether achieved through a nominal depreciation or internal deflation, raises the relative price of tradables vis-à-vis non-tradables, thus improving external balance by reducing consumption of tradables and simultaneously shifting resources to the tradable sector. It is well

\footnotetext{
${ }^{8}$ Interaction impacts on exports are somewhat more promising (results available upon request). Countries that have a higher share of commodity exports see a lower export increase with product market reform (electricity regulation, reduction in entry barriers) and labor market reform than those with a more diversified export base. The interaction coefficients of reform and the business cycle and also share of commodities in total exports on imports are insignificant, suggesting import demand is somewhat inelastic.
} 
documented that most of the adjustment comes from consumption and imports compression. ${ }^{9}$ However, the promise of a stronger tradable sector down the road is often seen as the silver lining of such adjustment programs. The same logic applies when the devaluation is triggered by an exogenous event, such as a term-of-trade shock in the case of a commodity exporter or a capital outflow caused by contagion in the case of an emerging market with an open capital account. A quick response of the tradable sector to a change in the real exchange rate can mitigate the shock, thus contributing to economic stability.

\section{Figure 1. Export and REER Developments in Euro Area Periphery Countries}
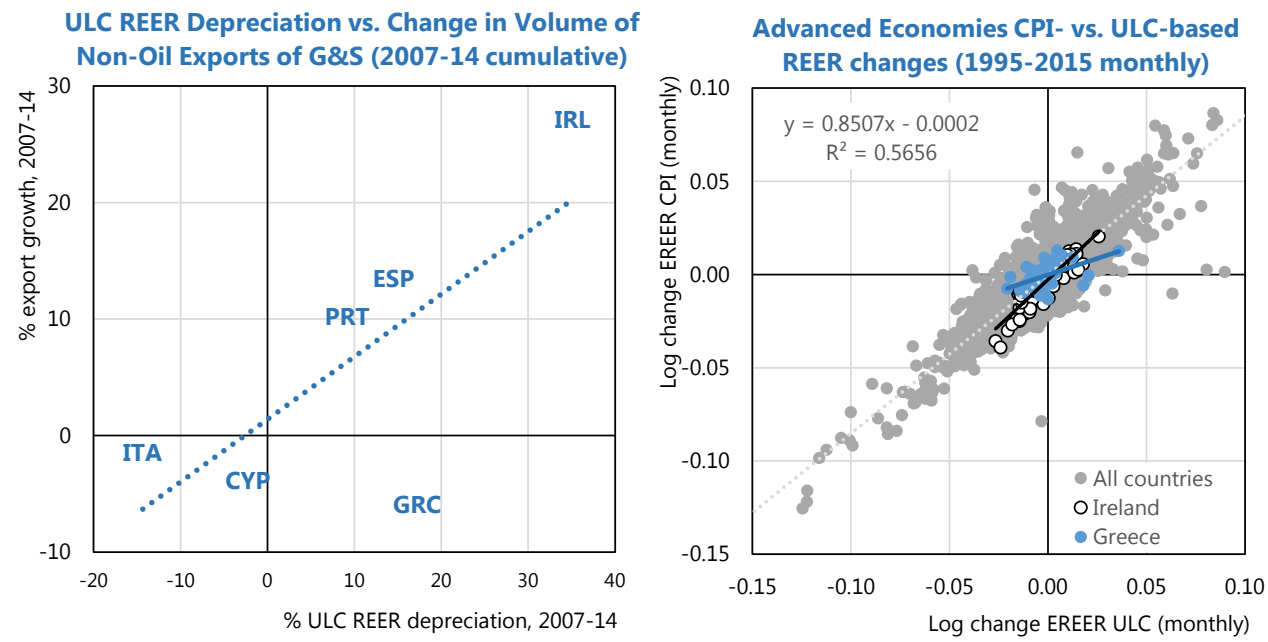

Countries vary in their success to boost exports on the back of a real devaluation. The varied experience of Euro Area deficit countries during and following the global financial crisis is a notable recent example. The left chart in Figure 1 shows that Greece saw a much smaller export dividend to its devaluation - as measured by unit labor cost (ULC) - than other countries in this group. Some explanations put forward for this disconnect include differences in trading partners (e.g., Ireland's sronger ties with the healthier, at the time, US and UK economies) and differences in the export basket (e.g., Greece's services are dominated by shipping, which collapsed during the GFC). However, the right chart in the figure supports an alternative explanation: cheap labor did not result in improved competitiveness. ${ }^{10}$ Using monthly data, we see that a given reduction in unit labor translated into a smaller CPI REER reduction than expected for an advanced economy. In Greece, a 1 percent ULC real depreciation is associated with a 0.35 depreciation in the CPI REER, compared to 0.85 for the aveage Advanced Economy. ${ }^{11}$ IMF (2015a) concludes that "the benefits of lower labor costs for competitiveness [were] blunted by limited adjustment in producer prices and supply response because of barriers to new entry”.

\footnotetext{
${ }^{9}$ IMF (2015a), Tressel et al. (2014).

${ }^{10}$ See Tressel et al. (2014) for details.

${ }^{11}$ Chart also highlights in black the individual observations for Ireland, which exhibits a slope of 0.99.
} 
The example above highlights the importance of product markets - ease of entry in particular - for a real devaluation to successfully spur exports. However, the argument can be broadened: facing a change in the real effective exchange rate, an economy with fewer frictions should be able to reallocate resources faster towards tradable activities and - within tradable activities - towards higher-productivity industries and firms. Labor and product market reforms remove impediments to the allocation of resources to the new equilibrium. A sound financial sector facilitates this reallocation by channeling the resources needed to finance the adjustment. Strong legal systems can mitigate risks associated with the transition, which would otherwise lead to underinvestment. Trade openness ensures inputs needed by new industries are readily available, and human capital and infrastructure endowments can reduce bottlenecks. Overall, a country with better structural indicators should exhibit a higher export response to movements in the exchange rate. The question is which reforms are more likely to affect the export response to exchange rate movements and how the response differs by country groups.

In what follows, we analyze the impact of structural indicators on the exports' response to REER movements using cross-country panel regressions. This allows for a robust estimation of the slope of the regression line in the left chart of Figure 1, which represents the percentage change in exports in response to a one percent change in the REER (e.g., around 0.5 in the figure). This slope - the elasticity of exports with respect to the REER - denotes

the sensitivity of exports to movements in the exchange rate. Multivariate regression analysis allows controlling for some other factors that can influence this relationship, such as the pattern of trading partners. The hypothesis is that the slope (elasticity) should increase as structural indicators improve, i.e., countries with better structural indicators should exhibit a higher export response to a given REER depreciation. Since different structural indicators are likely to be binding across economic structures, we also expect different types of indicators to matter across income groups.

\section{B. Econometric Specification}

We follow the general setup used by Eichengreen and Gupta (2013) for estimating the elasticity of exports with respect to the real effective exchange rate:

$$
\Delta \log X_{i t}=\beta_{1} \Delta \log R E E R_{i t}+\beta_{A}^{\prime} Z_{i t}+\omega_{i}+\eta_{t}+\varepsilon_{i t}
$$

where $X$ is real exports, $Z_{i t}$ is a $1 \times k$ vector of other factors affecting exports (Eichengreen and Gupta limit their controls to lagged GDP per capita), $\omega$ is a country dummy and $\eta$ is a time dummy. $\beta_{1}$ represents the estimated export elasticity with respect to the REER. For presentation purposes, we flip the sign of the first difference of the REER. Thus, a depreciation enters the regression with a positive sign, and the expected sign on $\beta_{1}$ is thus positive. We also introduce several changes to obtain the following specification:

$$
\Delta \log X_{i t}=\beta_{1} \Delta \log R E E R_{i t-1}+\beta_{2} \Delta \log R E E R_{i t-1} \times S_{i t-1}+\beta_{3} S_{i t-1}+\boldsymbol{\beta}_{A}^{\prime} \boldsymbol{Z}_{i t}+\omega_{i}+\eta_{t}+\varepsilon_{i t}
$$


First and foremost, we introduce the lagged level of a structural indicator $\left(S_{i t-1}\right)$ and its interaction with REER depreciation in order to estimate the differentiated elasticity at different values of the structural indicator, with the overall elasticity computed as $\beta_{1}+$ $\beta_{2} S_{i t-1}$.

Second, we use fairly narrow measures of exports as dependent variable. We focus on manufactured goods and services exports. The use of manufactured exports, as opposed to all goods exports, is determined by the desire to abstract from commodities, for which domestic price competitiveness play a relatively minor role (as the share of domestically-priced inputs is relatively low). As for services exports, Eichengreen and Gupta have already shown that they are more susceptible to exchange rate movements, and therefore more likely to exhibit measurably different responses as a function of structural indicators. The use of narrow measures of exports diminish concerns about reverse causality as manufacturing exports and services exports separately represent small shares of total current account flows (around 18 and 12 percent respectively for non-LICs). Therefore, their potential to have a significant impact on the REER is correspondingly smaller. This is an important factor behind using the REER on the right-hand side in this section, unlike in the previous one (which operated with much broader current account components).

Third, we lag the REER variable by one period, to further minimize reverse causality concerns. In any event, the reverse causality link would only tend to attenuate the results. An exogenous positive shock to exports should appreciate the exchange rate, thus dampening the measured correlation between depreciation and export growth.

Fourth, we use nominal measures of exports, as opposed to deflating all export prices by the US CPI. Although standard practice in the trade literature, this step is superfluous in a setup with time effects, as dollar inflation is captured by period dummies.

Fifth, we expand the set of controls. We introduce a country-specific deflator of goods export prices (when dependent variable is manufactured services) to proxy for changing price conditions on world markets, and we use the export-weighted real GDP growth in trading partners to control for external demand effects.

Finally, the use of lagged REER motivates the use of averaged data over shorter periods three years instead of five used by Eichengreen and Gupta and other studies.

\section{Results}

\section{Benchmark results}

Our benchmark regressions estimate export elasticities with respect to the REER without accounting for structural indicators. For brevity, Table 5 presents only regressions with manufacturing exports as the dependent variable. 
Table 5. Benchmark Regressions for Manufacturing Exports

\begin{tabular}{|c|c|c|c|c|c|c|c|c|c|c|c|c|c|c|c|}
\hline & \multicolumn{3}{|c|}{ All countries } & \multicolumn{3}{|c|}{ Non-LICs } & \multicolumn{3}{|c|}{ Advanced Economies } & \multicolumn{3}{|c|}{ Emerging Markets } & \multicolumn{3}{|c|}{ LICs } \\
\hline & (1) & (2) & (3) & (4) & (5) & (6) & (7) & (8) & (9) & (10) & (11) & (12) & (13) & (14) & (15) \\
\hline Lagged log change REER & $\begin{array}{c}0.141^{\star \star} \\
(0.0593)\end{array}$ & $\begin{array}{c}0.153^{\star \star} \\
(0.0683)\end{array}$ & $\begin{array}{c}0.135 \\
(0.0818)\end{array}$ & $\begin{array}{c}0.11 \\
(0.0881)\end{array}$ & $\begin{array}{l}0.193^{\star *} \\
(0.0734)\end{array}$ & $\begin{array}{l}0.214^{\star \star \star} \\
(0.0752)\end{array}$ & $\begin{array}{l}0.359^{\star \star \star} \\
(0.0645)\end{array}$ & $\begin{array}{l}0.343^{\star \star \star} \\
(0.0714)\end{array}$ & $\begin{array}{l}0.348^{\star \star \star} \\
(0.0735)\end{array}$ & $\begin{array}{c}0.0697 \\
(0.0999)\end{array}$ & $\begin{array}{c}0.167^{*} \\
(0.0937)\end{array}$ & $\begin{array}{c}0.180^{\star} \\
(0.0984)\end{array}$ & $\begin{array}{c}0.160^{\star} \\
(0.0776)\end{array}$ & $\begin{array}{c}0.187^{\star *} \\
(0.0823)\end{array}$ & $\begin{array}{c}0.156 \\
(0.0952)\end{array}$ \\
\hline Log change partner GDP & & $\begin{array}{l}15.21^{\star *} \\
(6.841)\end{array}$ & $\begin{array}{l}14.39^{\star \star} \\
(7.028)\end{array}$ & & $\begin{array}{l}9.620^{\star *} \\
(3.873)\end{array}$ & $\begin{array}{l}9.257^{\text {** }} \\
(3.899)\end{array}$ & & $\begin{array}{c}4.024 \\
(4.168)\end{array}$ & $\begin{array}{c}3.983 \\
(4.135)\end{array}$ & & $\begin{array}{l}11.90^{* *} \\
(5.553)\end{array}$ & $\begin{array}{l}11.54^{\star \star} \\
(5.483)\end{array}$ & & $\begin{array}{c}10.33 \\
(21.25)\end{array}$ & $\begin{array}{l}10.08 \\
(21.6)\end{array}$ \\
\hline Log change export deflator & & $\begin{array}{l}-0.173 \\
(0.147)\end{array}$ & $\begin{array}{l}-0.187 \\
(0.153)\end{array}$ & & $\begin{array}{c}0.0198 \\
(0.0903)\end{array}$ & $\begin{array}{c}0.0242 \\
(0.0906)\end{array}$ & & $\begin{array}{c}0.179^{\star \star} \\
(0.0652)\end{array}$ & $\begin{array}{l}0.175^{\star *} \\
(0.0662)\end{array}$ & & $\begin{array}{l}-0.0125 \\
(0.115)\end{array}$ & $\begin{array}{c}0.00246 \\
(0.118)\end{array}$ & & $\begin{array}{l}-0.679 \\
(0.448)\end{array}$ & $\begin{array}{c}-0.68 \\
(0.455)\end{array}$ \\
\hline Lagged GDP/capita, PPP & & & $\begin{array}{c}-0.0034 \\
(0.00371)\end{array}$ & & & $\begin{array}{l}0.00079 \\
(0.002)\end{array}$ & & & $\begin{array}{c}-0.005 \\
(0.0137)\end{array}$ & & & $\begin{array}{c}0.00058 \\
(0.00213)\end{array}$ & & & $\begin{array}{l}-0.0208 \\
(0.0132)\end{array}$ \\
\hline Observations & 665 & 628 & 619 & 543 & 512 & 506 & 221 & 210 & 210 & 322 & 302 & 296 & 122 & 116 & 113 \\
\hline Countries & 81 & 79 & 79 & 62 & 61 & 61 & 23 & 23 & 23 & 39 & 38 & 38 & 19 & 18 & 18 \\
\hline$R^{2}$ & 0.142 & 0.164 & 0.160 & 0.219 & 0.247 & 0.254 & 0.671 & 0.690 & 0.690 & 0.163 & 0.199 & 0.206 & 0.227 & 0.233 & 0.227 \\
\hline
\end{tabular}

Note: Standard errors in parentheses are robust and clustered by country. $*, * *, * * *$ indicate that coefficients are significant at 10, 5 and 1 percent levels respectively. All regressions inlcude country and time fixed effects.

These results corroborate a number of empirical findings in the recent literature. Some of these are attributable to all countries: the estimated elasticity of exports with respect to the real exchange rate is broadly in line with estimates in IMF (2015c), and exports are highly dependent on partner growth.

Heterogeneity across country groups is also in line with the literature. First, export elasticities exhibited by emerging markets (EMs) are lower than those for advanced economies (AEs), and the exchange rate has a lower predictive power (comparing the $\mathrm{R}^{2}$ in equations 7 and 10). This is compatible with the theoretical argument and empirical findings that participation in global value chains - relatively more important in EM export industries - tends to attenuate the price effect on exports. ${ }^{12}$ Emerging markets also exhibit a higher elasticity with respect to export partner growth, which is in line with the Cubeddu et al. (2014) finding that GDP growth in EMs is more dependent on partner growth than AEs. We find that, unlike AEs, EMs exports exhibit no response to changes in the export deflator-another difference that can be traced to the prevalence of global value chains in their export industries. ${ }^{13}$

Results for Low Income Countries (LICs) should be interpreted with greater care. LICs exhibit the expected sign for the exchange rate. However, LICs suffer from data limitations, constraining the set of usable countries to less than twenty, and the number of observations to barely above one hundred. Second, manufactured exports generally constitute a small subset of LICs' export baskets. This means, among other things, that the WEO-derived export deflator is a highly imperfect proxy for the price of manufactured exports.

\footnotetext{
${ }^{12}$ Exports by country in a global value chain incorporate a relatively high share of imported inputs. When the exchange rate depreciates, the price of those imported imports rises as well, therefore muting the competitiveness effect. The impact of global chai participation on trade elasticities is explored in, among others, Ahmed et al. (2015), Amiti et al. (2014), Cheng et al. (2015), IMF (2015c).

${ }^{13}$ Ollivaud et al. (2015) find that the elasticity of the terms of trade to the exchange rate is weaker in economies with a higher share of foreign value added in gross exports.
} 


\section{Introducing Structural Reforms}

We now augment the benchmark regressions above with two more terms: the lagged level of structural reform and its interaction with the REER. We focus on the same set of structural indicators as IMF (2015b), and test them one by one.

Table 6 presents a subset of results for advanced economies. The dependent variable is the same across all regressions - manufacturing exports. What changes is the structural indicator used in the second and third rows (banking in equation 1, security markets in equation 2, etc.). The table shows that several types of structural reforms are associated with higher export elasticities at standard levels of significance: security markets, legal systems and property rights, business regulation and labor market regulation.

Table 6. Manufacturing Exports Fixed Effects Regressions for Advanced Economies

\begin{tabular}{|c|c|c|c|c|c|c|c|}
\hline & 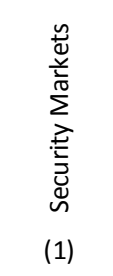 & 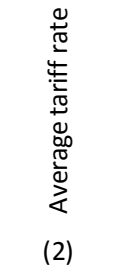 & 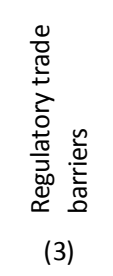 & 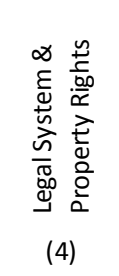 & 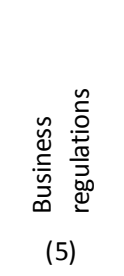 & 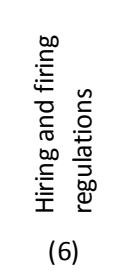 & 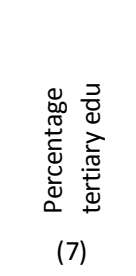 \\
\hline Lagged log change REER & $\begin{array}{l}-0.635^{*} \\
(0.355)\end{array}$ & $\begin{array}{l}-1.322 \\
(2.408)\end{array}$ & $\begin{array}{l}-0.268 \\
(0.490)\end{array}$ & $\begin{array}{l}-1.150^{*} \\
(0.659)\end{array}$ & $\begin{array}{l}-0.0846 \\
(0.168)\end{array}$ & $\begin{array}{l}-0.261 \\
(0.276)\end{array}$ & $\begin{array}{l}0.0896 \\
(0.185)\end{array}$ \\
\hline Lagged structural indicator & $\begin{array}{c}0.0119 \\
(0.0204)\end{array}$ & $\begin{array}{c}0.0300 \\
(0.0577)\end{array}$ & $\begin{array}{c}0.0125 \\
(0.00834)\end{array}$ & $\begin{array}{c}0.00439 \\
(0.00569)\end{array}$ & $\begin{array}{c}0.00812 \\
(0.00510)\end{array}$ & $\begin{array}{c}-0.00230 \\
(0.00648)\end{array}$ & $\begin{array}{c}-0.00270^{* *} \\
(0.00113)\end{array}$ \\
\hline Lagged log change REER * Lagged structural indicator & $\begin{array}{l}1.008^{* *} \\
(0.368)\end{array}$ & $\begin{array}{c}1.838 \\
(2.667)\end{array}$ & $\begin{array}{c}\mathbf{0 . 0 8 9 7} \\
(0.0650)\end{array}$ & $\begin{array}{c}0.187^{* *} \\
(0.0805)\end{array}$ & $\begin{array}{c}0.0775 * * \\
(0.0330)\end{array}$ & $\begin{array}{c}0.146^{* *} \\
(0.0606)\end{array}$ & $\begin{array}{c}\text { 0.0111* } \\
(0.00548)\end{array}$ \\
\hline Log change partner GDP & $\begin{array}{l}8.536^{* *} \\
(3.574)\end{array}$ & $\begin{array}{c}6.889 \\
(4.028)\end{array}$ & $\begin{array}{c}1.096 \\
(2.953)\end{array}$ & $\begin{array}{c}3.954 \\
(4.084)\end{array}$ & $\begin{array}{c}1.715 \\
(2.556)\end{array}$ & $\begin{array}{c}3.396 \\
(3.429)\end{array}$ & $\begin{array}{c}3.489 \\
(3.546)\end{array}$ \\
\hline Log change export deflator & $\begin{array}{l}0.177^{* *} \\
(0.0740)\end{array}$ & $\begin{array}{l}0.183^{* *} \\
(0.0681)\end{array}$ & $\begin{array}{c}0.318^{*} \\
(0.161)\end{array}$ & $\begin{array}{c}0.187^{* * *} \\
(0.0641)\end{array}$ & $\begin{array}{c}0.237^{*} \\
(0.138)\end{array}$ & $\begin{array}{c}0.207^{* *} \\
(0.0826)\end{array}$ & $\begin{array}{c}0.188^{* *} \\
(0.0708)\end{array}$ \\
\hline Observations & 184 & 187 & 108 & 210 & 129 & 149 & 210 \\
\hline $\begin{array}{l}\text { Countries } \\
R^{2}\end{array}$ & $\begin{array}{c}21 \\
0.723\end{array}$ & $\begin{array}{c}22 \\
0.704\end{array}$ & $\begin{array}{c}23 \\
0.732\end{array}$ & $\begin{array}{c}23 \\
0.697\end{array}$ & $\begin{array}{c}23 \\
0.698\end{array}$ & $\begin{array}{c}23 \\
0.636\end{array}$ & $\begin{array}{c}23 \\
0.706\end{array}$ \\
\hline
\end{tabular}

Note: Standard errors in parentheses are robust and clustered by country. ${ }^{*}, * *, * * *$ indicate that coefficients are significant at 10, 5 and 1 percent levels respectively. All regressions inlcude country and time fixed effects.

The above tabular presentation is not conducive to gauging the impact on the elasticity associated with a specific improvement in a given structural indicator. We propose a novel (to the best of our knowledge) and parsimonious presentation of marginal effects. 
Figure 2. Linear vs. Percentile Presentation of Marginal Effects
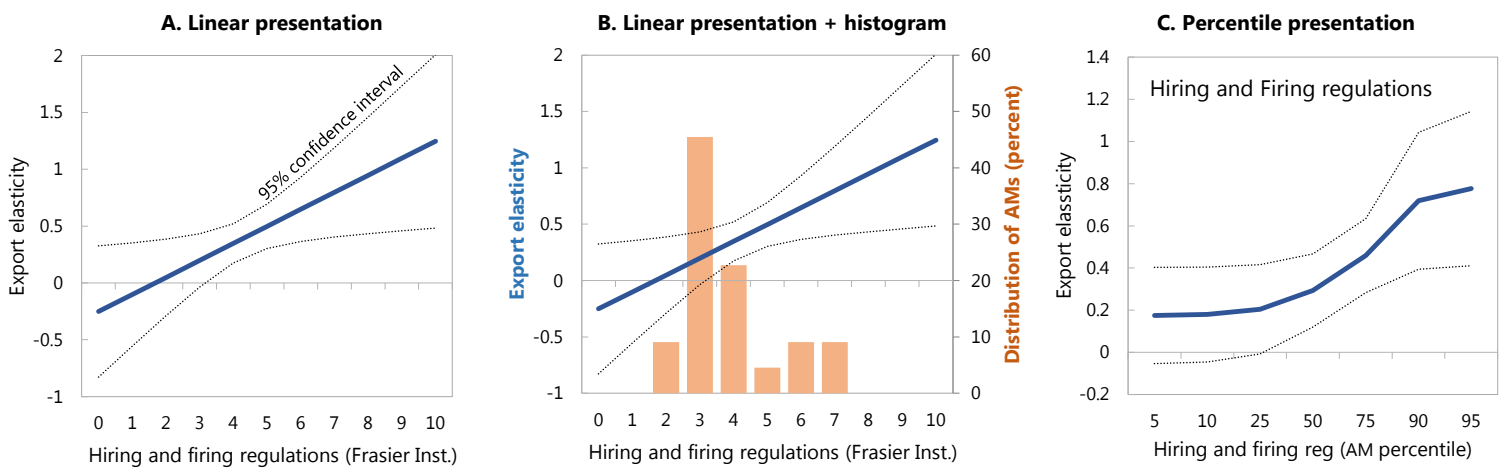

In chart A of Figure 2, we start with a standard graphic interpretation, where the intercept is given by the coefficient on the "lagged log change in REER" and the slope - by its interaction with the structural indicator; the hiring and firing regulations from the Frasier Institute in this example. This chart shows that moving from 1 to 8 on the scale is associated with the increase in elasticity from nil to 1 . However, this information is of limited use without knowing the current distribution of countries across the scale - we add the relevant histogram in chart B. Finally, in chart C, we combine the two series by replacing the linear horizontal axis with common percentile benchmarks (5, 10, 25, 50, 75, 90 and 95), which given the usual bell-shaped distribution of countries across the index scale - transforms the straight line into an S-shaped curve. From chart C, it is easy to read that, for example, moving from the $25^{\text {th }}$ to $75^{\text {th }}$ percentile on the hiring and firing regulations index is associated with an increase of the export elasticity from 0.2 to nearly 0.5 .

This presentation has multiple advantages. First, it helps compare impact of structural indicators measured on different scales. ${ }^{14}$ Second, the approach allows for comparing countries against the relevant benchmark group - Figure 2 only compares AEs. Third, for policy purposes, the absolute value of the indicator is generally less relevant than benchmarking, which is why country rankings is often the preferred method for presenting such datasets (e.g., World Bank’s Doing Business Indicators). Finally, the approach helps address at least one aspect of the perennial issue of economic vs. statistical significance - a variable may be statistically significant, but it may hold little policy value. Note that the percentiles are calculated based on the most recent distribution (the last five-year period for which data is available). It helps, in particular, to show that although the export REER elasticity exhibits a statistically significant relationship with some structural indicators, there is little (if any) room for further improvement on account of these indicators. For example, equation 2 in Table 6 shows that security markets are associated with higher export elasticities. However, this result is based on a regression that incorporates historical data going back to 1973, when advanced economies differed significantly in the level of

\footnotetext{
${ }^{14}$ Normalizing all indicators to a single scale also helps (e.g., min-max normalization or z-score transformation), but it is less transparent than the method proposed here.
} 
development (most scoring lower than currently). However, all AEs converged to 1 (the indicator's maximum value) by 1992, reflected in the horizontal marginal effect line.

Figure 3. Marginal Effects for Securities Markets
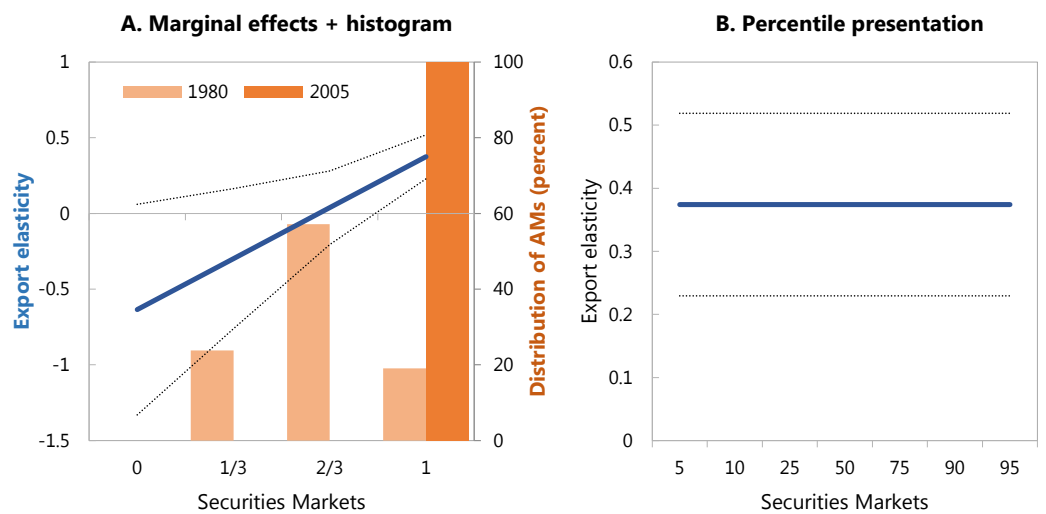

\section{Main Results}

The specific reforms that matter differ across income groups. Figure 4 offers selected highlights, and Table 7 summarizes the sign and statistical significance of various structural indicators. Full regression results are presented in Table A4-Table A8, and the full set of marginal effects in Figure A1-Figure A5.

Figure 4. Highlights of Main Results

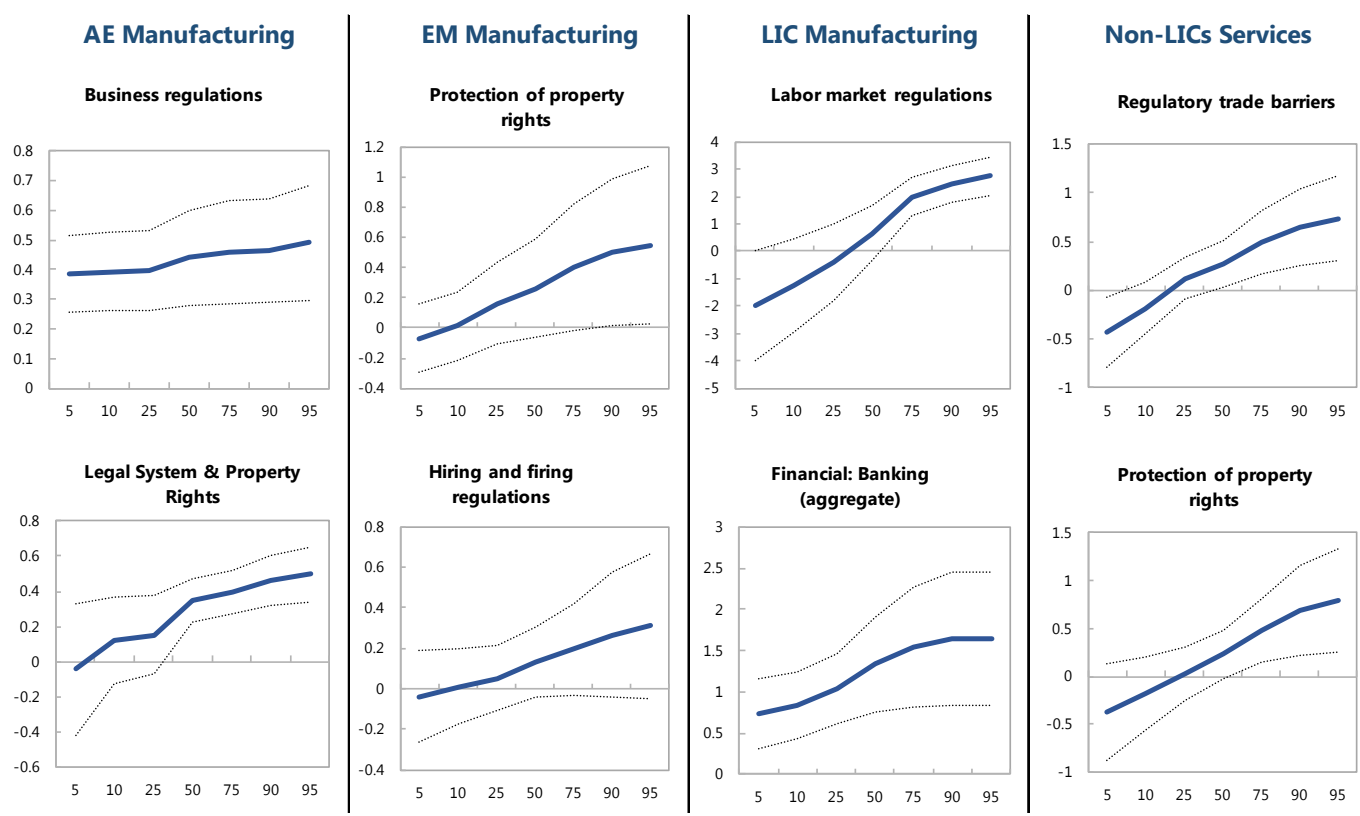

In advanced economies, labor and business regulations are the primary facilitators of the manufactured exports' response to REER movements. As discussed above, historically, securities markets were also an important facilitator of reallocation of resources to the tradable sector following depreciation episodes. However, as all AEs have developed 
sufficiently strong securities markets, their further development is unlikely to improve the resilience of the economy any further. We also find a positive and significant result on the share of population with tertiary education, which is an important factor of production in the export basket of a typical AE.

Institutional indicators are important in emerging markets, which is consistent with the prominent role played by cross-border supply chains, which rely heavily on a strong contracting environment. There is also a strong correlation with the share of population with secondary education, a factor of production more dominant in the export basket of a typical EM.

In low income countries, labor and banking sector regulations have a strong effect on export elasticities. However, as discussed above, the sample of LICs is limited, and manufacturing currently exports play a relatively smaller role in their export baskets, so these results should be treated with more caution.

Table 7. Indirect Impact: Summary of Main Results

\begin{tabular}{|c|c|c|c|c|c|c|}
\hline & \multicolumn{5}{|c|}{ Manufacturing } & \multirow{2}{*}{$\frac{\text { Services }}{\text { Non-LIC }}$} \\
\hline & All & Non-LIC & $\mathrm{AE}$ & EM & LIC & \\
\hline \multicolumn{7}{|l|}{ Financial sector } \\
\hline Banking & + & - & + & - & $+^{*}$ & $+* \star$ \\
\hline Security Markets & + & - & $+* \star$ & - & + & $+* \star \star$ \\
\hline \multicolumn{7}{|l|}{ Openness } \\
\hline Tariff Rates (average) & - & - & + & - & + & $+\star \star$ \\
\hline Regulatory trade barriers & $-^{*}$ & + & + & - & - & $+* \star \star$ \\
\hline \multicolumn{7}{|l|}{ Institutions } \\
\hline Protection of property rights & - & 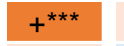 & + & $+* \star$ & - & $+\star \star$ \\
\hline Legal enforcement of contracts & + & + & - & + & + & $+\star \star$ \\
\hline \multicolumn{7}{|l|}{ Product market regulation } \\
\hline Business regulations & - & + & $+* \star$ & + & - & $+\star \star$ \\
\hline Product: telecom and electricity & - & $-^{\star}$ & + & - & + & + \\
\hline \multicolumn{7}{|l|}{ Labor } \\
\hline Hiring and firing regulations & $+* \star \star$ & + & $+* \star$ & + & $+* * *$ & - \\
\hline Centralized collective bargaining & $+^{*}$ & + & + & + & + & - \\
\hline \multicolumn{7}{|l|}{ Human capital and R\&D } \\
\hline Percentage of secondary & $+{ }^{*}$ & $+^{*}$ & - & $+* *$ & + & - \\
\hline Percentage of tertiary & - & + & $+^{*}$ & - & $-^{*}$ & - \\
\hline Basic R\&D spending & + & + & + & - & & - \\
\hline
\end{tabular}

Note: Table shows the sign on the interaction term between the lagged log change in REER and the lagged structural indicator. *, **, *** indicate that coefficients are significant at 10, 5 and 1 percent levels respectively. All regressions inlcude country and time fixed effects.

The table also presents results for services exports using Balance of Payments data for AMs and EMs. We find that services exhibit strong responses to REER movements in the presence of flexible financial sectors, trade openness, strong legal systems, and property rights. 
Table A9 presents extended results for a larger set of 24 variables, the most notable additions being indicators of infrastructure endowment. ${ }^{15}$ Here, we find that the positive link between structural reforms and REER export elasticities is most consistently established in the case of advanced economies - of the 24 structural variables tested in the wider set, 22 have the expected sign and seven are significant at least at the 10 percent level. For comparison, only seven structural indicators produce the expected positive sign in the case of emerging markets, although only one of the negative signs (restrictions on current account transactions) shows significance at the 10 percent level. LICs results are more in line with expectations most indicators exhibit the expected sign. However, they show a statistically significant negative correlation between infrastructure (electricity generation capacity and phone lines) and manufacturing export elasticity. ${ }^{16}$

\section{Extensions and Robustness}

Robustness checks include alternative measures of real exchange rates, annual data, and sensitivity to additional controls.

\section{Alternative REER measures}

The main results presented above are based on real depreciation derived from changes in the CPI-based REER. We now investigated two alternative measures of real exchange rates: the unit labor cost (ULC) based REER and the PPP REER, derived from Penn World Tables. As ULC data are available for a relatively small set of advanced and emerging economies, we only compared results for the non-LIC countries. Table A10 presents summary results on the sign and significance of the interaction term.

ULC REER results are even stronger than those based on CPI REER, especially with respect to labor market structural indicators. This can be expected, as ULC REER captures only those variations in price competitiveness that are determined domestically, and so are more susceptible to respond to internal structural conditions. On the other hand, changes in CPI REERs also reflect price changes in imported inputs, less likely to be influenced by the domestic structural environment. The ULC results do show, however, an unexpectedly and unexplainably strong negative impact of secondary education. The PPP-based results are similar to the main CPI-based results, with labor market flexibility showing a positive correlation with export response. Overall, the results confirm that the strongest link between structural indicators and REER export elasticities is found in labor market regulations.

\footnotetext{
${ }^{15}$ Although these are not indicators of structural reforms per se, one generally expect that better infrastructure constraints should be conducive to the reallocation of resources across sectors.

${ }^{16}$ It would not be surprising to find no relationship in the case of infrastructure. OECD input-output tables show that industries in the tradable sectors do not appear to be systematically more intensive in the use of utilities than non-tradable ones, so there is no additional pressure on infrastructure associated with the reallocation. However, this still does not explain the negative strong relationship found in the case of LICs.
} 


\section{Annual results}

The main results include data averaged over three years and, to minimize endogeneity concerns, the change in REER is lagged by one period. This means that a regression on the period average for $t-2$ through $t$ is affected by REER data as old as $t-8$. Generally, this is not an issue, as reallocation of resources across sectors and industries is a gradual process unlikely to be completed in a single year. However, existing exporters can respond to exchange rate changes immediately by reoptimizing the use of inputs, a process that can also be affected by structural conditions. Table A11 therefore presents summary results for annual data.

As expected, the results are weaker for annual data. However, strong legal systems and labor market flexibility retain their importance across country groups in the case of manufacturing exports, while results for services exports are not affected much. One unanticipated result is the strong negative short-term effect of human capital endowment, particularly in advanced economies. There is also a negative effect between $R \& D$ expenditure and short-term export price elasticities. Both findings can be explained by "pricing to market” practices in industries characterized by monopolistic competition, which are, generally, more R\&Dintensive and employ a more educated labor force. Pricing to market can also explain the strong negative correlation found for centralized and collective bargaining: large manufacturing industries (e.g., automotive) are more likely to price to market and to have a significant share of unionized labor. However, as pricing to market is a short-term strategy in the face of persistent REER movements exporters do ultimately adjust prices - these negative findings dissipate when analysis uses data averaged over three years.

\section{Export basket composition as alternative explanation}

One alternative explanation of the main results is that the differences in measured elasticities are in fact due to the composition of the export basket, and that good structural reforms are merely a reflection of diversification. The main set of results does not support this explanation, as we find large heterogeneities across reforms, which cannot be readily explained by the diversification hypothesis. Moreover, the focus on manufactured goods - as opposed to all goods exports - further homogenizes the types of goods compared across countries. Still, to test this alternative explanation, we augment the benchmark regressions with the Economic Complexity Index proposed by Hidalgo and Hausmann (2009). ${ }^{17}$ The index is the latest attempt in a strand of work synthesizing the sophistication of a country's

\footnotetext{
${ }^{17}$ Results using the diversification index from the IMF Diversification Toolkit (IMF (2014a) and IMF (2014b)) are identical and available upon request. We focus on ECI as it is generally a better predictor of growth outcomes; see for example Chapter 5 in IMF (2015d). ECI's advantage is that in addition to characterizing the diversity of the country's export basket, it also characterizes how "special" are the goods in the basket (determined indirectly from how many countries export that same good).
} 
tradable goods sector from the analysis of the disaggregated export basket. ${ }^{18}$ Table A12 shows that ECI has no effect on measured elasticities, as the interaction term between lagged ECI and lagged change in REER is not statistically significant. For EMs, the sign is in fact "wrong" - higher complexity is associated with lower elasticities. ${ }^{19}$ As complexity does not appear to influence REER export elasticities directly, it is unlikely to exert that impact indirectly, via structural reforms. ${ }^{20}$

\section{Conclusions And Policy Implications}

Our results call into question the time frame over which we can expect improvements in the current account from structural reforms. Even for large reform episodes (those larger than two standard deviations and those in the $5^{\text {th }}$ percentile of top reforms), we do not find overwhelming improvements in the current account balance in the short run. Over longer time horizons (3 to 5 years), the data provide some evidence that securities market development improves the current account, as do reforms in the telecom and electricity sectors. Not surprisingly, positive effects of research and development spending materialize on current account only in the longer term (4-5 years). Reforms have a stronger positive impact on exports. In particular, business regulation and better infrastructure are associated with a longer-term export response. These effects on the current account, however, are not strong due to the concomitant increase in imports. A stronger positive impact of reform on the current account may materialize beyond the 5-year horizon, but it is difficult to get robust results beyond the medium-term. We would need to account for reform reversals, and empirically the dynamic specification performs poorly in the long run.

We do, however, find that several structural indicators exhibit strong correlation with the elasticity of exports with respect to the real exchange rate. The types of structural reforms that are most likely to affect the responsiveness of exports to devaluations vary across country groups. Manufacturing exports in advanced economies are most susceptible to the presence of flexible labor and product market regulations. Emerging markets respond most to legal and institutional reforms. Low-income countries are also likely to respond to labor market flexibility. Elasticities for services exports are most susceptible to financial and trade reforms. Short-term effects - measured on annual data - paint a similar picture, although results are generally weaker. Overall, the strongest result pertains to labor market reforms,

\footnotetext{
${ }^{18}$ Indices developed as part of related work include the EXPY by Hausmann et al. (2007) and the location within product space by Hausmann and Klinger (2006).

${ }^{19}$ This result is also likely to be driven to the importance of supply value chains (which, as was discussed earlier, depress export elasticities) in the production of more sophisticated goods in emerging markets.

${ }^{20}$ Adding ECI into main results is complicated by the introduction of triple interaction effects (change in REER $\times E C I \times$ structural indicator) plus all bivariate combinations, which reduce degrees of freedom and complicates interpretation of results.
} 
which appear to be most conducive to reallocating resources to the tradable sector in the event of a real depreciation.

All results presented here are symmetrical. If manufacturing exports are likely to increase more in response to a real depreciation in the presence of flexible markets (AEs) or strong institutions (EMs), the same structural reforms will trigger a larger contraction of the tradable sector in the case of an appreciation. ${ }^{21}$ However, this is no argument against structural reforms. Equilibrium appreciations are generally responses to good news (e.g., a positive terms-of-trade shock), so an economy facing a real appreciation should be capable to compensate workers in affected industries. For that to happen, of course, the economy needs a well-functioning and well-targeted safety net. However, an appreciation can also take the economy away from equilibrium, for example if fueled by excessive capital inflows financing the unchecked growth in domestic credit. In such a case, flexible labor markets can in fact precipitate a sub-optimal downsizing of the tradable sector, which may later find it difficult to return to the previous size following the bust of the credit bubble. These examples underline that structural reforms should be undertaken while ensuring that the additional flexibility goes hand in hand with a safety net to compensate those affected by the shocks, as well as a regulatory framework to ensure that that this flexibility does not translate into a buildup of vulnerabilities.

Overall, our results paint a strong argument in favor of complementing macroeconomic adjustment programs with structural reforms. While expenditure-switching and expenditurereducing policies operate through both import and export channels, the general experience has been that imports play the dominant role in the adjustment. We show that structural reforms can help shift the external adjustment mix toward export growth. Moreover, structural reforms not only help deal with external imbalances at present, but also with any shocks the country faces down the road. Thus, in addition to helping boost growth, structural reforms can improve the resilience of the economy.

\footnotetext{
${ }^{21}$ Attempts to estimate the impact of structural reforms on export elasticities separately for appreciation and depreciation observations did not result in statistically significant differences.
} 


\section{BIBLIOGRAPHY}

Ahmed, S., M. Appendino, and M. Ruta, 2015, "Depreciations without Exports? Global Value Chains and the Exchange Rate Elasticity of Exports.” World Bank Policy Research Working Paper 7390, World Bank, Washington.

Amiti, M., O. Itskhoki, and J. Konings, 2014, “Importers, Exporters, and Exchange Rate Disconnect.” American Economic Review 104 (7): 1942-78.

Bouis, R., R. Duval, and J. Eugster, 2016, "Product Market Deregulation and Growth: New Country-Industry-Level Evidence.” IMF Working Paper No. 16/114, International Monetary Fund, Washington.

Bussière, M., M. Fratzscher, and G.J. Müller, 2005, “Productivity Shocks, Budget Deficits and the Current Account.” ECB Working Paper 509, European Central Bank, Frankfurt Am Main.

Cacciatore, M., R. Duval, G. Fiori, and F. Ghironi, 2016, "Short-Term Pain for Long-Term Gain: Market Deregulation and Monetary Policy in Small Open Economies.” Journal of International Money and Finance, 68 (2016), 358-385.

Cheng, K., S. Rehman, D. Seneviratne, and S. Zhang, 2015, "Reaping the Benefits from Global Value Chains.” IMF Working Paper No. 15/204, International Monetary Fund, Washington.

Cheung, C., D. Furceri, and Rusticelli, 2010, "Structural and Cyclical Factors Behind Current-Account Balances.” OECD Economics Department Working Papers, No. 775, OECD Publishing.

Cubeddu, L., A. Culiuc, G. Fayad, Y. Gao, K. Kochhar, A. Kyobe, C. Oner, R. Perrelli, S. Sanya, E. Tsounta, and Z. Zhang, 2014, “Emerging Markets In Transition: Growth Prospects And Challenges”, IMF Staff Discussion Note 14/06, International Monetary Fund, Washington.

Duval, R., 2008, "Is there a role for macroeconomic policy in fostering structural reforms? Panel evidence from OECD countries over the past two decades.” European Journal of Political Economy, 24 (2), 491-502.

Eichengree, B., and P. Gupta, 2013, “The Real Exchange Rate and Export Growth: Are Services Different?” World Bank Policy Research Working Paper 6629, World Bank, Washington. 
Fournier, J.-M., and I. Koske, 2010, “A Simple Model of the Relationship Between Productivity, Saving and the Current Account.” OECD Economics Department Working Papers, No. 816, OECD Publishing.

Glick, R., and K. Rogoff, 1995, "Global versus country-specific productivity shocks and the current account.” Journal of Monetary Economics, 35 (1995), 159-192.

Gregory, A., and A. Head, 1999, “Common and country-specific fluctuations in productivity, investment, and the current account.” Journal of Monetary Economics, 44(3), 423451.

Hausmann, R., J. Hwang and D. Rodrik, 2007, “What you export matters.” Journal of Economic Growth, 12(1), 1-25.

Hausmann, R., and B. Klinger, 2006, Structural transformation and patterns of comparative advantage in the product space. CID Working paper 128.

Hidalgo, C. and R. Hausmann, 2009, “The building blocks of economic complexity.” PNAS 106(26), 10570-10575.

Hoffman, M., 2001, “The relative Dynamics of investment in the Current Account in the G7Economies.” The Economic Journal, 111(471), 148-163.

Jaumotte, F., and P. Sodsriwiboon, 2010, “Current Account Imbalances in the Southern Euro Area”, IMF Working Paper 10/139, International Monetary Fund, Washington.

Jordà, Ò., 2005, “Estimation and Inference of Impulse Responses by Local Projections.” American Economic Review, 95(1), 161-182.

Kennedy, M., and T. Sløk, 2005, “Structural Policy Reforms and External Imbalances.” OECD Economics Department Working Papers, No. 415, OECD Publishing.

Kerdrain, C., I. Koske, and I. Wanner, 2010, “The Impact of Structural Policies on Saving, Investment and Current Accounts.” OECD Economics Department Working Papers, No. 815, OECD Publishing.

International Monetary Fund, 2013, “Greece: Ex Post Evaluation of Exceptional Access under the 2010 Stand-By Arrangement.” IMF Country Report No. 13/156, International Monetary Fund, Washington. , 2014a, "Sustaining Long-Run Growth and Macroeconomic Stability In Low-Income Countries-The Role Of Structural Transformation And Diversification.” IMF Policy Paper, International Monetary Fund, Washington. 
, 2014b, “The Diversification Toolkit: Export Diversification and Quality Databases.” https://www.imf.org/external/np/res/dfidimf/diversification.htm.

, 2015a, “Crisis Program Review.” International Monetary Fund, Washington.

, 2015b, "Structural Reforms and Macroeconomic Performance: Initial

Considerations For The Fund.” IMF Staff Report, International Monetary Fund, Washington.

, 2015c, “World Economic Outlook-October 2015.” International Monetary Fund, Washington.

, 2015d, "Western Hemisphere Regional Economic Outlook.” International Monetary Fund, Washington.

, 2016, “World Economic Outlook—April 2016.” International Monetary Fund, Washington.

, 2017, “2017 External Sector Report.” International Monetary Fund, Washington.

Nason, J., and J. Rogers, 2003, “The Present-Value Model of the Current Account Has Been Rejected: Round Up the Usual Suspects.” International Finance Discussion Paper 2003-760, board of Governors of the Federal Reserve System, Washington.

Ollivaud, P., E. Rusticelli, and C. Schwellnus, 2015, “The Changing Role of the Exchange Rate for Macroeconomic Adjustment.” OECD Economics Department Working Paper 1190, Organisation for Economic Co-operation and Development, Paris.

Tressel T., S. Wang, J.S. Kang, and J. Shambaugh, directed by J. Decressin and P. Koeva Brooks, 2014, “Adjustment in Euro Area Deficit Countries: Progress, Challenges, and Policies”, IMF Staff Discussion Note 14/7, International Monetary Fund, Washington. 
AnNeX 1. Data Sources

\begin{tabular}{|c|c|c|c|}
\hline Indicator & Source & Years & Countries \\
\hline \multicolumn{4}{|l|}{ Macroeconomic Indicators } \\
\hline Current Account & IMF WEO & $1960-2014$ & 192 \\
\hline Exports of Goods and Services & IMF WEO & $1960-2014$ & 192 \\
\hline Imports of Goods and Services & IMF WEO & $1960-2014$ & 192 \\
\hline Manufacturing exports & World Bank WDI & $1960-2013$ & 182 \\
\hline Services exports & World Bank WDI & $1960-2013$ & 99 \\
\hline GDP per capita, constant PPP \$ & IMF WEO & $1960-2013$ & 192 \\
\hline CPI REER & IMF IFS & $1979-2013$ & 95 \\
\hline ULC REER & IMF IFS & $1992-2013$ & 18 \\
\hline PPP REER & Penn World Tables & $1960-2010$ & 183 \\
\hline Deflator of exports of goods & IMF WEO & $1960-2013$ & 177 \\
\hline Trading partner GDP growth & Derived from IMF WEO \& DOT & $1960-2013$ & 174 \\
\hline Banking, debt and currency crises & Laeven and Valencia (2013) & 1970-2011 & 116 \\
\hline \multicolumn{4}{|l|}{ Structural indicators } \\
\hline \multicolumn{4}{|l|}{ Financial sector } \\
\hline Banking & Abiad et al. (2008) & $1973-2005$ & 87 \\
\hline Interest rate controls & Abiad et al. (2008) & 1973-2005 & 87 \\
\hline Directed credit/reserve requirements & Abiad et al. (2008) & $1973-2005$ & 87 \\
\hline Privatization & Abiad et al. (2008) & $1973-2005$ & 87 \\
\hline Banking Supervision & Abiad et al. (2008) & $1973-2005$ & 87 \\
\hline Security Markets & Abiad et al. (2008) & $1973-2005$ & 87 \\
\hline \multicolumn{4}{|l|}{ Openness } \\
\hline Tariff Rates (average) & Prati et al. (2012) & $1960-2006$ & 134 \\
\hline Regulatory trade barriers & Fraser Institute & $1995-2011$ & 143 \\
\hline Restrictions on current account transactions & Quinn et al. (2011) & $1960-2006$ & 114 \\
\hline Restrictions on capital account transactions & Quinn et al. (2011) & $1960-2006$ & 114 \\
\hline \multicolumn{4}{|l|}{ Institutions } \\
\hline Legal System \& Property Rights & Fraser Institute & 1970-2011 & 143 \\
\hline Protection of property rights & Fraser Institute & $1995-2011$ & 143 \\
\hline Legal enforcement of contracts & Fraser Institute & $2002-2011$ & 143 \\
\hline \multicolumn{4}{|l|}{ Product market regulation } \\
\hline Business regulations & Fraser Institute & $1995-2011$ & 143 \\
\hline Product: telecom and electricity & OECD & $1970-2003$ & 107 \\
\hline \multicolumn{4}{|l|}{ Infrastructure } \\
\hline Electricity production capacity & World Bank WDI & $1960-2012$ & 135 \\
\hline Telephone lines & World Bank WDI & $1960-2013$ & 188 \\
\hline Roads density & World Bank WDI & $1960-2010$ & 182 \\
\hline \multicolumn{4}{|l|}{ Labor } \\
\hline Labor market regulations & Fraser Institute / WEF GCR & $1970-2011$ & 143 \\
\hline Hiring and firing regulations & Fraser Institute / WEF GCR & $1990-2011$ & 135 \\
\hline Centralized collective bargaining & Fraser Institute / WEF GCR & $1970-2011$ & 135 \\
\hline \multicolumn{4}{|l|}{ Human capital and R\&D } \\
\hline Percentage of secondary & World Bank WDI & $1970-2010$ & 140 \\
\hline Percentage of tertiary & World Bank WDI & $1970-2010$ & 140 \\
\hline Basic R\&D spending & OECD & $1970-2010$ & 35 \\
\hline
\end{tabular}


Table A1. Effect of Reform on Current Account/GDP, baseline results

\begin{tabular}{|c|c|c|c|c|c|}
\hline & Year 1 & Year 2 & Year 3 & Year 4 & Year 5 \\
\hline \multirow[t]{2}{*}{ Banking sector reform } & $-5.449^{* \star}$ & -3.003 & -3.444 & -1.478 & 1.475 \\
\hline & $(2.376)$ & $(1.042)$ & $(1.159)$ & $(0.426)$ & $(0.399)$ \\
\hline Observations & 495 & 495 & 495 & 495 & 495 \\
\hline Countries & 84 & 84 & 84 & 84 & 84 \\
\hline$R^{2}$ & 0.155 & 0.241 & 0.313 & 0.319 & 0.271 \\
\hline \multirow[t]{2}{*}{ Securities market development } & 2.604 & $21.257^{\star \star}$ & $16.219^{\star \star}$ & $25.997^{\star \star \star}$ & $18.362^{\star \star}$ \\
\hline & $(0.408)$ & $(2.146)$ & $(2.356)$ & $(3.495)$ & (2.373) \\
\hline Observations & 121 & 121 & 121 & 121 & 121 \\
\hline Countries & 73 & 73 & 73 & 73 & 73 \\
\hline$R^{2}$ & 0.807 & 0.755 & 0.754 & 0.710 & 0.725 \\
\hline \multirow[t]{2}{*}{ Mean tariff rates } & -0.468 & $-0.891^{*}$ & $-1.737^{\star \star \star}$ & $-1.394^{\star \star}$ & $-1.232^{\star *}$ \\
\hline & $(1.179)$ & $(1.896)$ & $(3.021)$ & $(2.135)$ & $(2.088)$ \\
\hline Observations & 1,530 & 1,530 & 1,530 & 1,530 & 1,530 \\
\hline Countries & 109 & 109 & 109 & 109 & 109 \\
\hline$R^{2}$ & 0.259 & 0.305 & 0.281 & 0.272 & 0.452 \\
\hline \multirow[t]{2}{*}{ Regulatory trade barriers } & -0.228 & -0.649 & 0.374 & -0.270 & -0.904 \\
\hline & $(0.415)$ & $(0.730)$ & $(0.402)$ & $(0.267)$ & $(0.963)$ \\
\hline Observations & 541 & 541 & 540 & 540 & 539 \\
\hline Countries & 108 & 108 & 108 & 108 & 107 \\
\hline$R^{2}$ & 0.157 & 0.190 & 0.117 & 0.078 & 0.132 \\
\hline \multirow[t]{2}{*}{ Current account restrictions } & 1.139 & 3.355 & 3.515 & -0.144 & -4.420 \\
\hline & $(0.607)$ & $(1.212)$ & $(1.217)$ & $(0.050)$ & $(1.484)$ \\
\hline Observations & 400 & 400 & 400 & 400 & 400 \\
\hline Countries & 93 & 93 & 93 & 93 & 93 \\
\hline$R^{2}$ & 0.419 & 0.329 & 0.322 & 0.408 & 0.393 \\
\hline \multirow[t]{2}{*}{ Capital account restrictions } & -4.787 & 1.956 & 0.745 & -2.873 & -2.474 \\
\hline & $(1.750)$ & $(0.480)$ & $(0.153)$ & $(0.679)$ & (0.571) \\
\hline Observations & 148 & 148 & 148 & 148 & 148 \\
\hline Countries & 72 & 72 & 72 & 72 & 72 \\
\hline$R^{2}$ & 0.683 & 0.624 & 0.648 & 0.655 & 0.604 \\
\hline \multirow[t]{2}{*}{ Legal system \& Property rights } & -0.785 & -1.304 & -1.451 & -0.380 & -1.763 \\
\hline & $(1.768)$ & (2.034) & $(1.515)$ & $(0.481)$ & $(1.036)$ \\
\hline Observations & 1,542 & 1,542 & 1,541 & 1,540 & 1,540 \\
\hline Countries & 115 & 115 & 115 & 115 & 115 \\
\hline$R^{2}$ & 0.062 & 0.120 & 0.110 & 0.087 & 0.044 \\
\hline \multirow[t]{2}{*}{ Protection of property rights } & -0.211 & -0.596 & 0.226 & -0.230 & -0.734 \\
\hline & $(0.424)$ & $(0.939)$ & $(0.346)$ & $(0.340)$ & $(1.456)$ \\
\hline Observations & 486 & 486 & 485 & 485 & 485 \\
\hline Countries & 101 & 101 & 100 & 100 & 100 \\
\hline$R^{2}$ & 0.184 & 0.190 & 0.149 & 0.108 & 0.161 \\
\hline \multirow[t]{2}{*}{ Business regulation } & -1.041 & -1.777 & -1.556 & -1.381 & -1.320 \\
\hline & $(1.882)$ & $(1.323)$ & $(1.290)$ & (1.126) & $(1.079)$ \\
\hline Observations & 455 & 455 & 454 & 454 & 454 \\
\hline Countries & 94 & 94 & 93 & 93 & 93 \\
\hline$R^{2}$ & 0.155 & 0.229 & 0.156 & 0.145 & 0.194 \\
\hline
\end{tabular}

(continued on next page) 
Table A1. Effect of Reform on Current Account/GDP, baseline results (continued)

\begin{tabular}{|c|c|c|c|c|c|}
\hline & Year 1 & Year 2 & Year 3 & Year 4 & Year 5 \\
\hline \multirow[t]{2}{*}{ Product market regulation } & -4.107 & -18.402 & -21.831 & -5.160 & 3.774 \\
\hline & $(0.334)$ & $(1.344)$ & $(1.447)$ & $(0.349)$ & $(0.244)$ \\
\hline Observations & 81 & 81 & 81 & 81 & 81 \\
\hline Countries & 15 & 15 & 15 & 15 & 15 \\
\hline $\mathrm{R}^{2}$ & 0.534 & 0.625 & 0.661 & 0.610 & 0.694 \\
\hline \multirow[t]{2}{*}{ Telecom and electricity regulation } & -2.510 & 4.530 & 3.813 & 4.472 & 4.264 \\
\hline & $(1.046)$ & $(2.139)$ & $(1.123)$ & $(1.704)$ & $(1.225)$ \\
\hline Observations & 197 & 197 & 197 & 197 & 197 \\
\hline Countries & 82 & 82 & 82 & 82 & 82 \\
\hline$R^{2}$ & 0.462 & 0.523 & 0.517 & 0.584 & 0.396 \\
\hline \multirow[t]{2}{*}{ Infrastructure electricity } & 0.535 & 3.885 & 1.902 & 0.537 & -0.175 \\
\hline & $(0.211)$ & $(1.229)$ & $(0.487)$ & $(0.143)$ & $(0.049)$ \\
\hline Observations & 2,240 & 2,240 & 2,240 & 2,239 & 2,238 \\
\hline Countries & 107 & 107 & 107 & 107 & 107 \\
\hline $\mathrm{R}^{2}$ & 0.073 & 0.070 & 0.085 & 0.069 & 0.053 \\
\hline \multirow[t]{2}{*}{ Infrastructure telecom } & -5.563 & -2.526 & -3.600 & -2.119 & -3.152 \\
\hline & $(1.321)$ & $(0.912)$ & $(0.863)$ & $(0.529)$ & $(0.728)$ \\
\hline Observations & 2,786 & 2,786 & 2,785 & 2,784 & 2,783 \\
\hline Countries & 129 & 129 & 129 & 129 & 129 \\
\hline$R^{2}$ & 0.184 & 0.255 & 0.241 & 0.272 & 0.306 \\
\hline \multirow[t]{2}{*}{ Infrastructure roads } & -1.206 & -6.626 & 1.074 & 1.338 & -4.308 \\
\hline & $(0.343)$ & (1.122) & $(0.188)$ & (0.199) & (1.047) \\
\hline Observations & 685 & 685 & 684 & 683 & 682 \\
\hline Countries & 112 & 112 & 112 & 112 & 112 \\
\hline $\mathrm{R}^{2}$ & 0.155 & 0.272 & 0.247 & 0.274 & 0.255 \\
\hline \multirow[t]{2}{*}{ Hiring and firing regulation } & -0.252 & -0.125 & -0.334 & -0.854 & -0.016 \\
\hline & $(0.531)$ & $(0.197)$ & $(0.449)$ & $(1.028)$ & $(0.024)$ \\
\hline Observations & 358 & 358 & 358 & 358 & 358 \\
\hline Countries & 98 & 98 & 98 & 98 & 98 \\
\hline $\mathrm{R}^{2}$ & 0.250 & 0.330 & 0.305 & 0.279 & 0.337 \\
\hline \multirow[t]{2}{*}{ Collective bargaining } & -0.527 & 0.161 & 0.378 & 0.580 & 1.151 \\
\hline & $(1.008)$ & $(0.221)$ & $(0.363)$ & $(0.600)$ & $(1.222)$ \\
\hline Observations & 411 & 411 & 411 & 411 & 411 \\
\hline Countries & 95 & 95 & 95 & 95 & 95 \\
\hline $\mathrm{R}^{2}$ & 0.088 & 0.215 & 0.198 & 0.264 & 0.329 \\
\hline \multirow[t]{2}{*}{ Research and development spending } & 19.839 & 17.182 & 11.836 & 40.486 & 62.149 \\
\hline & $(1.186)$ & $(1.224)$ & $(0.807)$ & $(1.953)$ & (2.585) \\
\hline Observations & 323 & 323 & 323 & 323 & 323 \\
\hline Countries & 32 & 32 & 32 & 32 & 32 \\
\hline$R^{2}$ & 0.198 & 0.236 & 0.267 & 0.291 & 0.364 \\
\hline
\end{tabular}

Note: Standard errors in parentheses are robust and clustered by country. $*, * *, * * *$ indicate that coefficients are significant at 10, 5 and 1 percent levels respectively. All regressions inlcude country and time fixed effects. 
Table A2. Effect of Reform on Exports of Goods and Services/GDP, baseline results

\begin{tabular}{|c|c|c|c|c|c|}
\hline & Year 1 & Year 2 & Year 3 & Year 4 & Year 5 \\
\hline \multirow[t]{2}{*}{ Banking sector reform } & 2.498 & 1.193 & 2.982 & 5.322 & 9.719 \\
\hline & $(1.147)$ & $(0.335)$ & $(0.677)$ & $(0.901)$ & $(1.447)$ \\
\hline Observations & 409 & 406 & 403 & 401 & 399 \\
\hline Countries & 81 & 79 & 79 & 79 & 79 \\
\hline$R^{2}$ & 0.228 & 0.214 & 0.235 & 0.255 & 0.298 \\
\hline \multirow[t]{2}{*}{ Mean tariff rates } & 0.111 & 0.235 & 0.301 & -0.005 & -0.325 \\
\hline & $(0.451)$ & $(0.719)$ & $(0.807)$ & $(0.011)$ & $(0.604)$ \\
\hline Observations & 1,431 & 1,414 & 1,376 & 1,309 & 1,234 \\
\hline Countries & 112 & 111 & 109 & 108 & 108 \\
\hline$R^{2}$ & 0.142 & 0.183 & 0.148 & 0.139 & 0.124 \\
\hline \multirow[t]{2}{*}{ Regulatory trade barriers } & 0.152 & -0.034 & 0.081 & 0.598 & 0.457 \\
\hline & $(0.283)$ & $(0.046)$ & $(0.094)$ & $(0.572)$ & $(0.408)$ \\
\hline Observations & 712 & 699 & 655 & 611 & 557 \\
\hline Countries & 110 & 109 & 105 & 104 & 100 \\
\hline$R^{2}$ & 0.175 & 0.226 & 0.212 & 0.222 & 0.195 \\
\hline \multirow[t]{2}{*}{ Current account restrictions } & 3.271 & 1.209 & 3.348 & 2.839 & 3.502 \\
\hline & $(1.460)$ & $(0.525)$ & $(1.423)$ & $(1.297)$ & (1.283) \\
\hline Observations & 287 & 282 & 275 & 271 & 268 \\
\hline Countries & 82 & 81 & 80 & 80 & 78 \\
\hline$R^{2}$ & 0.332 & 0.373 & 0.410 & 0.419 & 0.415 \\
\hline \multirow[t]{2}{*}{ Capital account restrictions } & -0.263 & -0.357 & -0.391 & -0.776 & -0.908 \\
\hline & $(0.843)$ & $(0.741)$ & $(0.753)$ & $(1.213)$ & (1.630) \\
\hline Observations & 518 & 512 & 499 & 486 & 469 \\
\hline Countries & 91 & 91 & 89 & 85 & 84 \\
\hline $\mathrm{R}^{2}$ & 0.178 & 0.200 & 0.195 & 0.214 & 0.285 \\
\hline \multirow[t]{2}{*}{ Legal system and property rights } & -0.656 & 0.051 & 0.551 & 0.286 & 0.940 \\
\hline & $(1.533)$ & $(0.083)$ & $(0.594)$ & $(0.261)$ & $(0.778)$ \\
\hline Observations & 1,391 & 1,366 & 1,293 & 1,236 & 1,184 \\
\hline Countries & 117 & 115 & 112 & 110 & 107 \\
\hline $\mathrm{R}^{2}$ & 0.092 & 0.112 & 0.109 & 0.115 & 0.127 \\
\hline \multirow[t]{2}{*}{ Protection of property rights } & -0.060 & -0.162 & -0.596 & -0.706 & -0.666 \\
\hline & $(0.236)$ & $(0.391)$ & $(1.304)$ & $(1.185)$ & $(1.281)$ \\
\hline Observations & 603 & 593 & 541 & 495 & 476 \\
\hline Countries & 106 & 105 & 101 & 98 & 97 \\
\hline$R^{2}$ & 0.184 & 0.214 & 0.207 & 0.259 & 0.255 \\
\hline \multirow[t]{2}{*}{ Business regulation } & -0.789 & 0.387 & 0.030 & -1.168 & -1.411 \\
\hline & $(1.401)$ & $(0.322)$ & $(0.024)$ & $(1.239)$ & $(1.363)$ \\
\hline Observations & 589 & 579 & 527 & 507 & 468 \\
\hline Countries & 106 & 104 & 98 & 95 & 90 \\
\hline$R^{2}$ & 0.184 & 0.197 & 0.221 & 0.275 & 0.320 \\
\hline \multirow[t]{2}{*}{ Telecom and electricity regulation } & 4.143 & 5.981 & 7.166 & 5.876 & 6.561 \\
\hline & (3.113) & $(2.700)$ & $(2.435)$ & (2.039) & $(2.290)$ \\
\hline Observations & 172 & 170 & 169 & 167 & 166 \\
\hline Countries & 73 & 73 & 72 & 71 & 70 \\
\hline$R^{2}$ & 0.470 & 0.452 & 0.428 & 0.450 & 0.486 \\
\hline
\end{tabular}

(continued on next page) 
Table A2. Effect of Reform on Exports of Goods and Services/GDP, baseline results (continued)

\begin{tabular}{lccccc}
\hline & Year 1 & Year 2 & Year 3 & Year 4 & Year 5 \\
\hline Electricity infrastructure & 1.630 & 3.378 & 5.288 & 6.701 & 5.156 \\
& $(1.282)$ & $(2.179)$ & $(2.259)$ & $(1.931)$ & $(1.459)$ \\
Observations & 2,027 & 1,980 & 1,892 & 1,790 & 1,725 \\
Countries & 111 & 111 & 111 & 110 & 107 \\
$\mathrm{R}^{2}$ & 0.096 & 0.100 & 0.092 & 0.101 & 0.108 \\
\hline Telecom infrastructure & 1.061 & 1.875 & 3.622 & 2.322 & 2.197 \\
& $(0.973)$ & $(1.041)$ & $(1.546)$ & $(0.782)$ & $(0.573)$ \\
Observations & 2,257 & 2,195 & 2,102 & 2,016 & 1,930 \\
Countries & 135 & 132 & 132 & 130 & 126 \\
$\mathrm{R}^{2}$ & 0.090 & 0.087 & 0.091 & 0.097 & 0.112 \\
\hline Road infrastructure & 3.717 & -1.976 & 0.545 & 5.562 & 5.659 \\
& $(1.051)$ & $(0.486)$ & $(0.110)$ & $(0.974)$ & $(0.959)$ \\
Observations & 628 & 614 & 602 & 559 & 517 \\
Countries & 103 & 99 & 98 & 92 & 90 \\
$\mathrm{R}^{2}$ & 0.234 & 0.213 & 0.230 & 0.201 & 0.175 \\
\hline Hiring and firing regulations & & & & & \\
& -0.348 & -0.060 & -0.147 & 0.914 & 1.047 \\
Observations & $(1.164)$ & $(0.124)$ & $(0.213)$ & $(1.151)$ & $(1.424)$ \\
Countries & 569 & 555 & 494 & 439 & 388 \\
$\mathrm{R}^{2}$ & 106 & 104 & 100 & 96 & 95 \\
\hline Collective bargaining & 0.200 & 0.224 & 0.235 & 0.268 & 0.296 \\
\hline Observations & -0.297 & -0.243 & -0.791 & -1.196 & -1.360 \\
Countries & $(0.846)$ & $(0.310)$ & $(1.163)$ & $(1.482)$ & $(1.168)$ \\
$\mathrm{R}^{2}$ & 582 & 575 & 524 & 482 & 439 \\
Research and development spending & 105 & 104 & 99 & 97 & 93 \\
Observations & 0.236 & 0.237 & 0.242 & 0.258 & 0.266 \\
Countries & -11.168 & -10.365 & -2.755 & 2.558 & 35.225 \\
$\mathrm{R}^{2}$ & $(1.070)$ & $(0.852)$ & $(0.125)$ & $(0.118)$ & $(1.400)$ \\
\hline
\end{tabular}

Note: Standard errors in parentheses are robust and clustered by country. ${ }^{*}, * *, * * *$ indicate that coefficients are significant at 10, 5 and 1 percent levels respectively. All regressions inlcude country and time fixed effects. 
Table A3. Effect of Reform on Imports of Goods and Services/GDP, baseline results

\begin{tabular}{|c|c|c|c|c|c|}
\hline & Year 1 & Year 2 & Year 3 & Year 4 & Year 5 \\
\hline \multirow[t]{2}{*}{ Banking sector reform } & 0.781 & 4.990 & 7.486 & 8.781 & 9.902 \\
\hline & $(0.225)$ & $(0.875)$ & $(1.143)$ & $(1.146)$ & $(1.170)$ \\
\hline Observations & 455 & 455 & 455 & 455 & 455 \\
\hline Countries & 83 & 83 & 83 & 83 & 83 \\
\hline $\mathrm{R}^{2}$ & 0.221 & 0.239 & 0.218 & 0.274 & 0.313 \\
\hline \multirow[t]{2}{*}{ Mean tariff rates } & -0.010 & 0.214 & 0.568 & $0.883^{*}$ & 0.584 \\
\hline & $(0.036)$ & $(0.450)$ & $(1.014)$ & $(1.666)$ & $(0.807)$ \\
\hline Observations & 1,596 & 1,595 & 1,595 & 1,594 & 1,594 \\
\hline Countries & 125 & 125 & 125 & 125 & 125 \\
\hline $\mathrm{R}^{2}$ & 0.180 & 0.228 & 0.240 & 0.232 & 0.247 \\
\hline \multirow[t]{2}{*}{ Regulatory trade barriers } & 0.211 & 0.780 & 1.333 & 0.350 & 1.018 \\
\hline & $(0.409)$ & $(1.178)$ & $(1.570)$ & $(0.418)$ & $(1.208)$ \\
\hline Observations & 798 & 798 & 797 & 796 & 795 \\
\hline Countries & 127 & 127 & 127 & 127 & 127 \\
\hline $\mathrm{R}^{2}$ & 0.260 & 0.352 & 0.357 & 0.320 & 0.314 \\
\hline \multirow[t]{2}{*}{ Current account restrictions } & 2.766 & -3.847 & -3.104 & 2.070 & $8.808^{*}$ \\
\hline & $(0.676)$ & $(1.057)$ & $(0.717)$ & $(0.450)$ & $(1.946)$ \\
\hline Observations & 371 & 371 & 371 & 371 & 371 \\
\hline Countries & 85 & 85 & 85 & 85 & 85 \\
\hline $\mathrm{R}^{2}$ & 0.451 & 0.349 & 0.399 & 0.427 & 0.419 \\
\hline \multirow[t]{2}{*}{ Capital account restrictions } & -0.209 & -0.398 & -0.473 & -0.828 & -0.868 \\
\hline & $(0.375)$ & $(0.622)$ & $(0.710)$ & $(0.945)$ & $(1.260)$ \\
\hline Observations & 567 & 566 & 566 & 566 & 565 \\
\hline Countries & 110 & 110 & 110 & 110 & 110 \\
\hline $\mathrm{R}^{2}$ & 0.651 & 0.462 & 0.579 & 0.551 & 0.539 \\
\hline \multirow[t]{2}{*}{ Legal system and property rights } & -0.865 & -0.689 & -0.754 & -1.563 & -2.878 \\
\hline & $(1.354)$ & $(0.745)$ & $(0.652)$ & $(1.228)$ & $(2.284)$ \\
\hline Observations & 1,667 & 1,667 & 1,667 & 1,666 & 1,664 \\
\hline Countries & 132 & 132 & 132 & 132 & 132 \\
\hline $\mathrm{R}^{2}$ & 0.146 & 0.193 & 0.201 & 0.212 & 0.214 \\
\hline \multirow[t]{2}{*}{ Protection of property rights } & -0.210 & 0.357 & -0.022 & 0.218 & 0.304 \\
\hline & $(0.550)$ & $(0.666)$ & $(0.033)$ & $(0.311)$ & $(0.555)$ \\
\hline Observations & 669 & 669 & 669 & 667 & 667 \\
\hline Countries & 118 & 118 & 118 & 117 & 117 \\
\hline $\mathrm{R}^{2}$ & 0.209 & 0.343 & 0.341 & 0.332 & 0.292 \\
\hline \multirow[t]{2}{*}{ Business regulation } & 0.352 & 2.054 & 2.484 & 2.108 & 2.948 \\
\hline & $(0.444)$ & $(1.698)$ & $(1.622)$ & $(1.712)$ & $(2.287)$ \\
\hline Observations & 642 & 642 & 641 & 640 & 639 \\
\hline Countries & 118 & 118 & 118 & 117 & 117 \\
\hline$R^{2}$ & 0.275 & 0.341 & 0.328 & 0.325 & 0.384 \\
\hline
\end{tabular}

(continued on next page) 
Table A3. Effect of Reform on Imports of Goods and Services/GDP, baseline results (continued)

\begin{tabular}{|c|c|c|c|c|c|}
\hline & Year 1 & Year 2 & Year 3 & Year 4 & Year 5 \\
\hline \multirow[t]{2}{*}{ Telecom and electricity regulation } & -1.545 & 0.390 & 2.303 & 3.743 & 3.678 \\
\hline & $(0.775)$ & $(0.112)$ & $(0.565)$ & $(0.914)$ & $(0.936)$ \\
\hline Observations & 206 & 206 & 206 & 206 & 206 \\
\hline Countries & 84 & 84 & 84 & 84 & 84 \\
\hline $\mathrm{R}^{2}$ & 0.556 & 0.517 & 0.483 & 0.457 & 0.465 \\
\hline \multirow[t]{2}{*}{ Electricity infrastructure } & 1.444 & 0.834 & -0.405 & 1.112 & 1.982 \\
\hline & $(0.930)$ & $(0.509)$ & $(0.204)$ & $(0.419)$ & $(0.798)$ \\
\hline Observations & 2,328 & 2,327 & 2,326 & 2,325 & 2,323 \\
\hline Countries & 117 & 117 & 117 & 117 & 117 \\
\hline $\mathrm{R}^{2}$ & 0.123 & 0.127 & 0.112 & 0.128 & 0.138 \\
\hline \multirow[t]{2}{*}{ Telecom infrastructure } & 0.720 & 4.536 & 3.468 & 4.160 & 1.917 \\
\hline & $(0.344)$ & $(1.313)$ & $(1.186)$ & $(1.108)$ & $(0.584)$ \\
\hline Observations & 2,991 & 2,990 & 2,989 & 2,988 & 2,987 \\
\hline Countries & 150 & 150 & 150 & 150 & 150 \\
\hline $\mathrm{R}^{2}$ & 0.192 & 0.121 & 0.152 & 0.184 & 0.177 \\
\hline \multirow[t]{2}{*}{ Road infrastructure } & -1.395 & -6.123 & -2.496 & -7.077 & -0.123 \\
\hline & $(0.400)$ & $(1.425)$ & $(0.596)$ & $(1.304)$ & $(0.031)$ \\
\hline Observations & 799 & 798 & 797 & 796 & 794 \\
\hline Countries & 121 & 121 & 121 & 121 & 121 \\
\hline $\mathrm{R}^{2}$ & 0.221 & 0.254 & 0.371 & 0.472 & 0.474 \\
\hline \multirow[t]{2}{*}{ Hiring and firing regulations } & 0.077 & -0.034 & -0.487 & -0.709 & -0.091 \\
\hline & $(0.156)$ & $(0.053)$ & $(0.655)$ & $(0.787)$ & $(0.095)$ \\
\hline Observations & 625 & 624 & 624 & 623 & 622 \\
\hline Countries & 117 & 116 & 116 & 116 & 116 \\
\hline $\mathrm{R}^{2}$ & 0.285 & 0.333 & 0.355 & 0.304 & 0.329 \\
\hline \multirow[t]{2}{*}{ Collective bargaining } & 0.055 & 0.216 & -0.370 & -1.467 & -0.156 \\
\hline & $(0.102)$ & $(0.293)$ & $(0.393)$ & $(1.389)$ & $(0.157)$ \\
\hline Observations & 640 & 639 & 638 & 636 & 635 \\
\hline Countries & 118 & 118 & 117 & 117 & 117 \\
\hline $\mathrm{R}^{2}$ & 0.331 & 0.341 & 0.325 & 0.305 & 0.309 \\
\hline \multirow[t]{2}{*}{ Research and development spending } & -8.481 & -20.054 & -24.302 & -2.681 & 7.293 \\
\hline & $(0.694)$ & $(1.259)$ & $(1.498)$ & $(0.153)$ & $(0.346)$ \\
\hline Observations & 385 & 385 & 385 & 385 & 385 \\
\hline Countries & 34 & 34 & 34 & 34 & 34 \\
\hline$R^{2}$ & 0.489 & 0.465 & 0.452 & 0.425 & 0.417 \\
\hline
\end{tabular}

Note: Standard errors in parentheses are robust and clustered by country. ${ }^{*}, * *, * * *$ indicate that coefficients are significant at 10, 5 and 1 percent levels respectively. All regressions inlcude country and time fixed effects. 
Table A4. Manufacturing Exports Country and Time Fixed Effects Regressions for Advanced Economies and Emerging Markets (Non-LICs)

\begin{tabular}{|c|c|c|c|c|c|c|c|c|c|c|c|c|c|c|}
\hline & 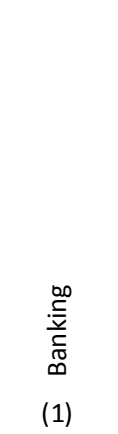 & 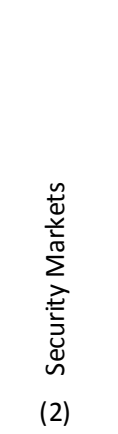 & 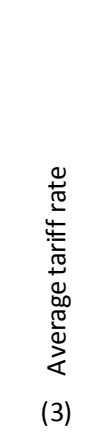 & 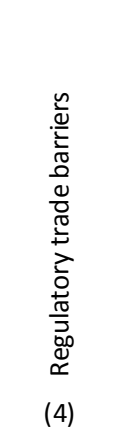 & 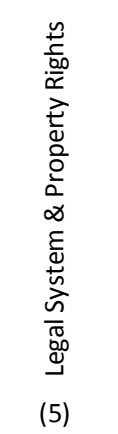 & 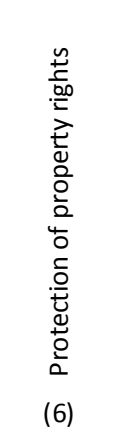 & 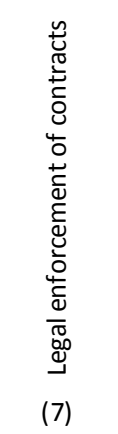 & 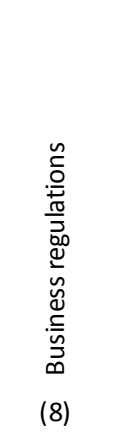 & 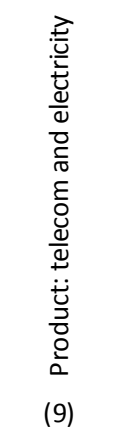 & 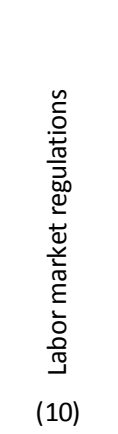 & 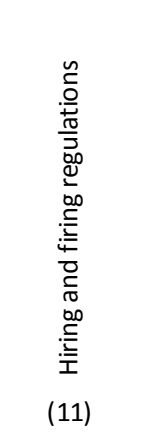 & 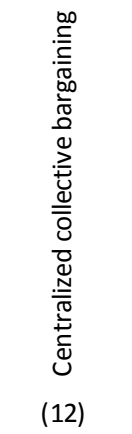 & 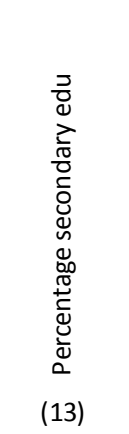 & 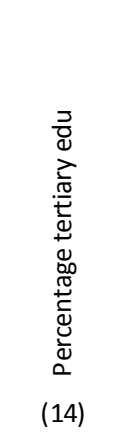 \\
\hline Lagged log change REER & $\begin{array}{c}0.224 \\
(0.261)\end{array}$ & $\begin{array}{c}0.270 \\
(0.215)\end{array}$ & $\begin{array}{c}0.495 \\
(0.351)\end{array}$ & $\begin{array}{l}0.0969 \\
(0.222)\end{array}$ & $\begin{array}{c}0.315 \\
(0.251)\end{array}$ & $\begin{array}{l}-0.321^{*} \\
(0.186)\end{array}$ & $\begin{array}{l}-0.621 \\
(0.547)\end{array}$ & $\begin{array}{l}-0.191 \\
(0.279)\end{array}$ & $\begin{array}{l}0.266^{* *} \\
(0.117)\end{array}$ & $\begin{array}{c}0.139 \\
(0.275)\end{array}$ & $\begin{array}{l}-0.142 \\
(0.182)\end{array}$ & $\begin{array}{l}-0.176 \\
(0.212)\end{array}$ & $\begin{array}{l}-0.132 \\
(0.229)\end{array}$ & $\begin{array}{c}0.197 \\
(0.146)\end{array}$ \\
\hline Lagged structural indicator & $\begin{array}{l}-0.0181 \\
(0.0364)\end{array}$ & $\begin{array}{r}-0.00610 \\
(0.0203)\end{array}$ & $\begin{array}{l}0.00305 \\
(0.0540)\end{array}$ & $\begin{array}{c}0.00280 \\
(0.00977)(\end{array}$ & $\begin{array}{c}0.00251 \\
(0.00773)\end{array}$ & $\begin{array}{l}0.00341 \\
(0.0101)\end{array}$ & $\begin{array}{c}-0.00259 \\
(0.00441)\end{array}$ & $\begin{array}{c}0.00420 \\
(0.00629)\end{array}$ & $\begin{array}{c}0.0127 \\
(0.0175)\end{array}$ & $\begin{array}{r}-0.0168 \\
(0.0300)\end{array}$ & $\begin{array}{c}0.0217^{* * *} \\
(0.00654)\end{array}$ & $\begin{array}{l}0.0158^{* *} \\
(0.00606)\end{array}$ & $\begin{array}{c}0.000180 \\
(0.000698)\end{array}$ & $\begin{array}{r}-0.00115 \\
(0.00137)\end{array}$ \\
\hline Lagged log change REER * Lagged structural indicator & $\begin{array}{l}-0.0955 \\
(0.356)\end{array}$ & $\begin{array}{r}-0.165 \\
(0.271)\end{array}$ & $\begin{array}{l}-0.405 \\
(0.458)\end{array}$ & $\begin{array}{l}\mathbf{0 . 0 0 7 1 4} \\
(0.0371)\end{array}$ & $\begin{array}{l}-0.01110 \\
(0.0378)\end{array}$ & $\begin{array}{c}0.0946 * * * \\
(0.0309)\end{array}$ & $\begin{array}{c}0.183 \\
(0.111)\end{array}$ & $\begin{array}{c}\mathbf{0 . 0 6 5 9} \\
(0.0495)\end{array}$ & $\begin{array}{l}-0.498^{*} \\
(0.278)\end{array}$ & $\begin{array}{l}-0.0424 \\
(0.170)\end{array}$ & $\begin{array}{c}0.0632 \\
(0.0403)\end{array}$ & $\begin{array}{c}0.0751 \\
(0.0469)\end{array}$ & $\begin{array}{l}\text { 0.00882* } \\
(0.00491)\end{array}$ & $\begin{array}{c}\mathbf{0 . 0 0 1 0 5} \\
(0.00672)\end{array}$ \\
\hline Log change partner GDP & $\begin{array}{l}11.88^{* *} \\
(4.910)\end{array}$ & $\begin{array}{l}11.88^{* *} \\
(4.859)\end{array}$ & $\begin{array}{l}11.19 * * \\
(4.946)\end{array}$ & $\begin{array}{l}8.169 * \\
(4.341)\end{array}$ & $\begin{array}{l}8.828^{* *} \\
(3.827)\end{array}$ & $\begin{array}{c}7.391^{*} \\
(4.158)\end{array}$ & $\begin{array}{l}13.91^{* *} \\
(5.947)\end{array}$ & $\begin{array}{l}8.095^{* *} \\
(3.432)\end{array}$ & $\begin{array}{c}15.39 * * * \\
(2.616)\end{array}$ & $\begin{array}{c}6.490 \\
(4.474)\end{array}$ & $\begin{array}{c}10.71^{* * *} \\
(2.764)\end{array}$ & $\begin{array}{l}8.156^{* *} \\
(3.385)\end{array}$ & $\begin{array}{l}9.677^{* *} \\
(3.976)\end{array}$ & $\begin{array}{l}9.791^{* *} \\
(4.143)\end{array}$ \\
\hline Log change export deflator & $\begin{array}{c}0.114 \\
(0.0883)\end{array}$ & $\begin{array}{c}0.114 \\
(0.0891)\end{array}$ & $\begin{array}{l}0.0828 \\
(0.114)\end{array}$ & $\begin{array}{c}0.158 \\
(0.140)\end{array}$ & $\begin{array}{c}0.0626 \\
(0.108)\end{array}$ & $\begin{array}{c}0.188 \\
(0.140)\end{array}$ & $\begin{array}{c}-0.0754 \\
(0.221)\end{array}$ & $\begin{array}{c}0.0861 \\
(0.138)\end{array}$ & $\begin{array}{c}0.131 \\
(0.0830)\end{array}$ & $\begin{array}{l}0.0927 \\
(0.137)\end{array}$ & $\begin{array}{c}0.122 \\
(0.0990)\end{array}$ & $\begin{array}{c}0.205 \\
(0.128)\end{array}$ & $\begin{array}{r}0.00503 \\
(0.0889)\end{array}$ & $\begin{array}{r}0.00424 \\
(0.0847)\end{array}$ \\
\hline Observations & 387 & 387 & 426 & 256 & 485 & 253 & 174 & 295 & 314 & 328 & 380 & 321 & 497 & 497 \\
\hline Countries & 49 & 49 & 57 & 60 & 60 & 59 & 60 & 60 & 46 & 61 & 60 & 59 & 59 & 59 \\
\hline$R^{2}$ & 0.286 & 0.287 & 0.255 & 0.431 & 0.256 & 0.460 & 0.559 & 0.415 & 0.426 & 0.160 & 0.497 & 0.459 & 0.260 & 0.256 \\
\hline
\end{tabular}

Note: Standard errors in parentheses are robust and clustered by country. ${ }^{*}, * * * * *$ indicate that coefficients are significant at 10,5 and 1 percent levels respectively. All regressions inlcude country and time fixed effects. 
Table A5. Manufacturing Exports Country and Time Fixed Effects Regressions for Advanced Economies

\begin{tabular}{|c|c|c|c|c|c|c|c|c|c|c|c|c|c|c|}
\hline & 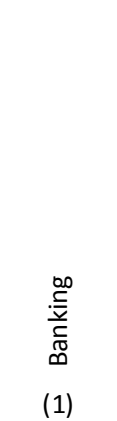 & 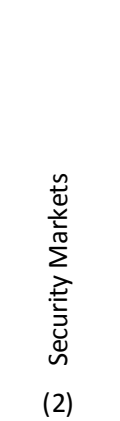 & 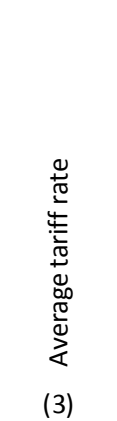 & 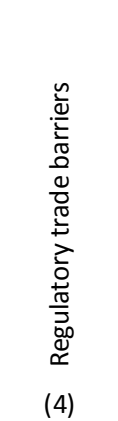 & 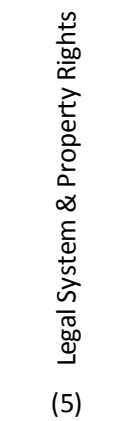 & 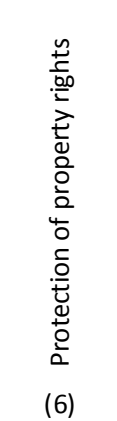 & 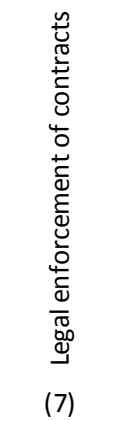 & 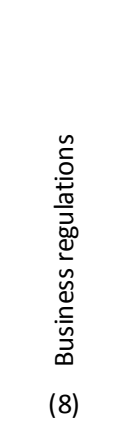 & 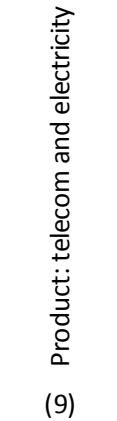 & 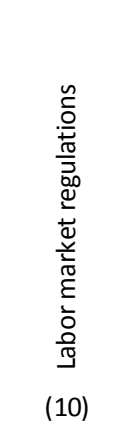 & 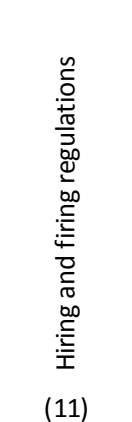 & 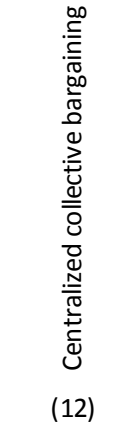 & 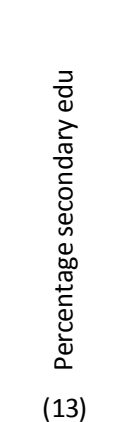 & 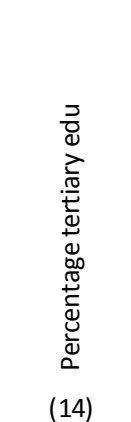 \\
\hline Lagged log change REER & $\begin{array}{l}-0.0569 \\
(0.445)\end{array}$ & $\begin{array}{l}-0.635^{*} \\
(0.355)\end{array}$ & $\begin{array}{l}-1.322 \\
(2.408)\end{array}$ & $\begin{array}{l}-0.268 \\
(0.490)\end{array}$ & $\begin{array}{c}-1.150^{*} \\
(0.659)\end{array}$ & $\begin{array}{l}-0.119 \\
(0.689)\end{array}$ & $\begin{array}{c}1.184 \\
(0.992)\end{array}$ & $\begin{array}{l}-0.0846 \\
(0.168)\end{array}$ & $\begin{array}{c}0.223 \\
(0.134)\end{array}$ & $\begin{array}{l}-0.199 \\
(0.294)\end{array}$ & $\begin{array}{c}-0.261 \\
(0.276)\end{array}$ & $\begin{array}{c}0.151 \\
(0.328)\end{array}$ & $\begin{array}{c}0.466 \\
(0.318)\end{array}$ & $\begin{array}{l}0.0896 \\
(0.185)\end{array}$ \\
\hline Lagged structural indicator & $\begin{array}{l}0.00495 \\
(0.0223)\end{array}$ & $\begin{array}{c}0.0119 \\
(0.0204)\end{array}$ & $\begin{array}{c}0.0300 \\
(0.0577)\end{array}$ & $\begin{array}{c}0.0125 \\
(0.00834)\end{array}$ & $\begin{array}{c}0.00439 \\
(0.00569)( \\
()\end{array}$ & $\begin{array}{c}0.00383 \\
(0.00634)\end{array}$ & $\begin{array}{c}-0.0103^{*} \\
(0.00535)\end{array}$ & $\begin{array}{c}0.00812 \\
(0.00510)\end{array}$ & $\begin{array}{c}0.0105 \\
(0.0111)\end{array}$ & $\begin{array}{c}0.00680 \\
(0.00457)\end{array}$ & $\begin{array}{c}-0.00230 \\
(0.00648)\end{array}$ & $\begin{array}{l}0.000818 \\
(0.00534)\end{array}$ & $\begin{array}{c}0.000341 \\
(0.000259)\end{array}$ & $\begin{array}{l}-0.00270^{* *} \\
(0.00113)\end{array}$ \\
\hline Lagged log change REER * Lagged structural indicator & $\begin{array}{c}0.480 \\
(0.563)\end{array}$ & $\begin{array}{l}1.008^{* *} \\
(0.368)\end{array}$ & $\begin{array}{c}1.838 \\
(2.667)\end{array}$ & $\begin{array}{c}0.0897 \\
(0.0650)\end{array}$ & $\begin{array}{l}0.187^{* *} \\
(0.0805)\end{array}$ & $\begin{array}{c}\mathbf{0 . 0 7 8 4} \\
(0.0939)\end{array}$ & $\begin{array}{c}-0.101 \\
(0.146)\end{array}$ & $\begin{array}{c}0.0775 * * \\
(0.0330)\end{array}$ & $\begin{array}{c}\mathbf{0 . 2 9 6} \\
(0.328)\end{array}$ & $\begin{array}{l}0.0825^{*} \\
(0.0448)\end{array}$ & $\begin{array}{l}0.146 * * \\
(0.0606)\end{array}$ & $\begin{array}{c}\mathbf{0 . 0 2 8 5} \\
(0.0462)\end{array}$ & $\begin{array}{c}-0.00251 \\
(0.00643)\end{array}$ & $\begin{array}{c}\mathbf{0 . 0 1 1 1 *}^{*} \\
(0.00548)\end{array}$ \\
\hline Log change partner GDP & $\begin{array}{l}8.331^{* *} \\
(3.433)\end{array}$ & $\begin{array}{l}8.536^{* *} \\
(3.574)\end{array}$ & $\begin{array}{c}6.889 \\
(4.028)\end{array}$ & $\begin{array}{c}1.096 \\
(2.953)\end{array}$ & $\begin{array}{c}3.954 \\
(4.084)\end{array}$ & $\begin{array}{c}1.950 \\
(3.260)\end{array}$ & $\begin{array}{c}4.550 \\
(7.537)\end{array}$ & $\begin{array}{c}1.715 \\
(2.556)\end{array}$ & $\begin{array}{c}10.32^{* * *} \\
(3.530)\end{array}$ & $\begin{array}{l}6.135 * * \\
(2.633)\end{array}$ & $\begin{array}{c}3.396 \\
(3.429)\end{array}$ & $\begin{array}{l}6.211^{*} \\
(3.164)\end{array}$ & $\begin{array}{c}4.008 \\
(4.079)\end{array}$ & $\begin{array}{c}3.489 \\
(3.546)\end{array}$ \\
\hline Log change export deflator & $\begin{array}{l}0.174^{* *} \\
(0.0681)\end{array}$ & $\begin{array}{l}0.177^{* *} \\
(0.0740)\end{array}$ & $\begin{array}{l}0.183^{* *} \\
(0.0681)\end{array}$ & $\begin{array}{c}0.318^{*} \\
(0.161)\end{array}$ & $\begin{array}{c}0.187^{* * *} \\
(0.0641)\end{array}$ & $\begin{array}{l}0.372^{*} \\
(0.183)\end{array}$ & $\begin{array}{c}0.199 \\
(0.232)\end{array}$ & $\begin{array}{c}0.237^{*} \\
(0.138)\end{array}$ & $\begin{array}{l}0.156^{* *} \\
(0.0698)\end{array}$ & $\begin{array}{l}0.162^{* *} \\
(0.0733)\end{array}$ & $\begin{array}{l}0.207^{* *} \\
(0.0826)\end{array}$ & $\begin{array}{c}0.153^{* *} \\
(0.0644)\end{array}$ & $\begin{array}{l}0.182^{* *} \\
(0.0697)\end{array}$ & $\begin{array}{c}0.188^{* *} \\
(0.0708)\end{array}$ \\
\hline Observations & 184 & 184 & 187 & 108 & 210 & 108 & 67 & 129 & 163 & 206 & 149 & 209 & 210 & 210 \\
\hline Countries & 21 & 21 & 22 & 23 & 23 & 23 & 23 & 23 & 21 & 23 & 23 & 23 & 23 & 23 \\
\hline$R^{2}$ & 0.718 & 0.723 & 0.704 & 0.732 & 0.697 & 0.724 & 0.821 & 0.698 & 0.701 & 0.717 & 0.636 & 0.709 & 0.691 & 0.706 \\
\hline
\end{tabular}

Note: Standard errors in parentheses are robust and clustered by country. ${ }^{* * *}, * * *$ indicate that coefficients are significant at 10,5 and 1 percent levels respectively. All regressions inlcude country and time fixed effects. 
Table A6. Manufacturing Exports Fixed Effects Regressions for Emerging Markets

\begin{tabular}{|c|c|c|c|c|c|c|c|c|c|c|c|c|c|c|}
\hline & 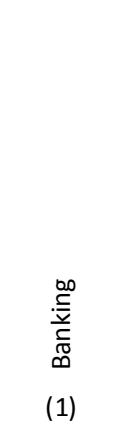 & 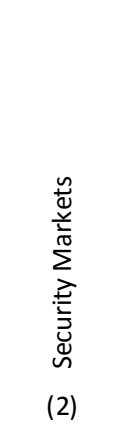 & 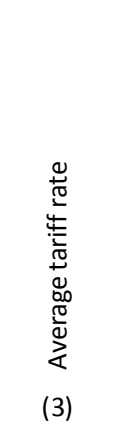 & 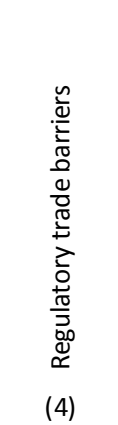 & 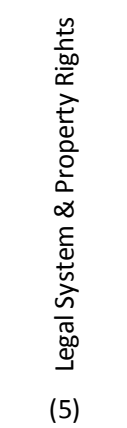 & 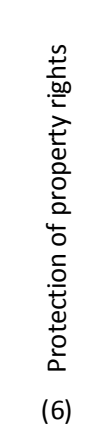 & 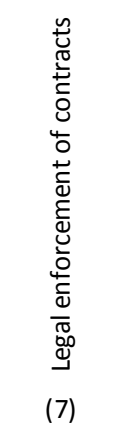 & 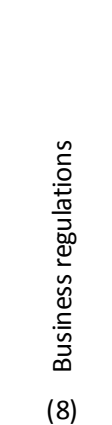 & 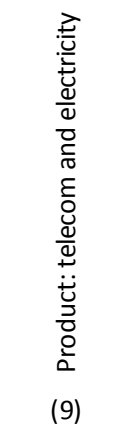 & 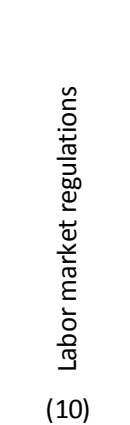 & 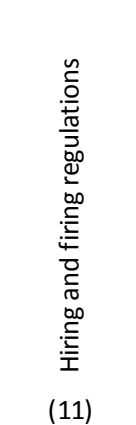 & 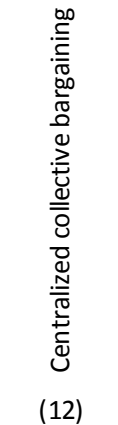 & 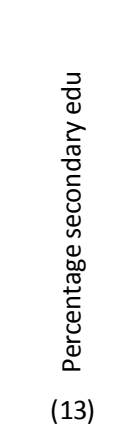 & 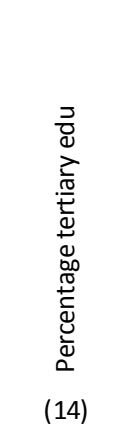 \\
\hline Lagged log change REER & $\begin{array}{c}0.152 \\
(0.320)\end{array}$ & $\begin{array}{c}0.207 \\
(0.217)\end{array}$ & $\begin{array}{c}0.566 \\
(0.415)\end{array}$ & $\begin{array}{c}0.137 \\
(0.334)\end{array}$ & $\begin{array}{c}0.320 \\
(0.347)\end{array}$ & $\begin{array}{c}0.320 \\
(0.347)\end{array}$ & $\begin{array}{c}-0.447^{* *} \\
(0.210)\end{array}$ & $\begin{array}{l}-0.228 \\
(0.426)\end{array}$ & $\begin{array}{c}0.242 \\
(0.181)\end{array}$ & $\begin{array}{c}0.255 \\
(0.547)\end{array}$ & $\begin{array}{l}-0.297 \\
(0.279)\end{array}$ & $\begin{array}{l}-0.402 \\
(0.376)\end{array}$ & $\begin{array}{l}-0.303 \\
(0.258)\end{array}$ & $\begin{array}{c}0.205 \\
(0.177)\end{array}$ \\
\hline Lagged structural indicator & $\begin{array}{l}0.00421 \\
(0.0866)\end{array}$ & $\begin{array}{c}0.0220 \\
(0.0318)\end{array}$ & $\begin{array}{c}0.0102 \\
(0.0719)\end{array}$ & $\begin{array}{l}0.00835 \\
(0.0152)\end{array}$ & $\begin{array}{c}0.00536 \\
(0.00832)\end{array}$ & $\begin{array}{c}0.00536 \\
(0.00832)\end{array}$ & $\begin{array}{c}0.0103 \\
(0.0175)\end{array}$ & $\begin{array}{c}0.0139 \\
(0.0111)\end{array}$ & $\begin{array}{c}0.0180 \\
(0.0366)\end{array}$ & $\begin{array}{l}0.0254^{* *} \\
(0.00943)\end{array}$ & $\begin{array}{l}0.0230^{* * *} \\
(0.00740)\end{array}$ & $\begin{array}{c}0.0181 \\
(0.0138)\end{array}$ & $\begin{array}{l}0.000891 \\
(0.00193)\end{array}$ & $\begin{array}{c}-0.00162 \\
(0.00294)\end{array}$ \\
\hline Lagged log change REER * Lagged structural indicator & $\begin{array}{r}-0.133 \\
(0.435)\end{array}$ & $\begin{array}{l}-0.254 \\
(0.317)\end{array}$ & $\begin{array}{l}-0.556 \\
(0.600)\end{array}$ & $\begin{array}{r}-0.00630 \\
(0.0601)\end{array}$ & $\begin{array}{l}-0.0160 \\
(0.0596)\end{array}$ & $\begin{array}{l}-0.0160 \\
(0.0596)\end{array}$ & $\begin{array}{l}0.132^{* *} \\
(0.0553)\end{array}$ & $\begin{array}{c}0.0729 \\
(0.0902)\end{array}$ & $\begin{array}{r}-0.581 \\
(0.342)\end{array}$ & $\begin{array}{l}-\mathbf{0 . 0 2 6 2} \\
(0.125)\end{array}$ & $\begin{array}{c}0.0913 \\
(0.0648)\end{array}$ & $\begin{array}{c}\mathbf{0 . 0 7 5 3} \\
(0.0651)\end{array}$ & $\begin{array}{l}\mathbf{0 . 0 1 2 6 * *} \\
(0.00574)\end{array}$ & $\begin{array}{c}-0.00218 \\
(0.00921)\end{array}$ \\
\hline Log change partner GDP & $\begin{array}{l}14.86^{* *} \\
(7.036)\end{array}$ & $\begin{array}{l}14.68^{* *} \\
(7.101)\end{array}$ & $\begin{array}{l}13.51^{*} \\
\text { (7.161) }\end{array}$ & $\begin{array}{c}11.60^{*} \\
(6.524)\end{array}$ & $\begin{array}{l}11.40^{* *} \\
(5.614)\end{array}$ & $\begin{array}{l}11.40^{* *} \\
(5.614)\end{array}$ & $\begin{array}{c}10.77^{*} \\
(6.004)\end{array}$ & $\begin{array}{l}13.64^{* *} \\
(5.413)\end{array}$ & $\begin{array}{c}17.19 * * * \\
(3.830)\end{array}$ & $\begin{array}{c}15.31^{* * *} \\
(5.282)\end{array}$ & $\begin{array}{l}11.58^{* *} \\
(4.908)\end{array}$ & $\begin{array}{l}12.63^{* *} \\
(4.790)\end{array}$ & $\begin{array}{l}12.39 * * \\
(5.893)\end{array}$ & $\begin{array}{l}12.79 * * \\
(6.041)\end{array}$ \\
\hline Log change export deflator & $\begin{array}{c}0.113 \\
(0.112)\end{array}$ & $\begin{array}{c}0.117 \\
(0.123)\end{array}$ & $\begin{array}{l}0.0553 \\
(0.150)\end{array}$ & $\begin{array}{c}0.101 \\
(0.147)\end{array}$ & $\begin{array}{l}0.0187 \\
(0.145)\end{array}$ & $\begin{array}{l}0.0187 \\
(0.145)\end{array}$ & $\begin{array}{c}0.168 \\
(0.149)\end{array}$ & $\begin{array}{l}0.0219 \\
(0.175)\end{array}$ & $\begin{array}{c}0.131 \\
(0.137)\end{array}$ & $\begin{array}{l}0.0645 \\
(0.167)\end{array}$ & $\begin{array}{c}0.203 \\
(0.169)\end{array}$ & $\begin{array}{c}0.119 \\
(0.130)\end{array}$ & $\begin{array}{l}-0.0188 \\
(0.117)\end{array}$ & $\begin{array}{l}-0.0129 \\
(0.111)\end{array}$ \\
\hline Observations & 203 & 203 & 239 & 148 & 275 & 275 & 145 & 166 & 151 & 174 & 172 & 185 & 287 & 287 \\
\hline $\begin{array}{l}\text { Countries } \\
R^{2}\end{array}$ & $\begin{array}{c}28 \\
0.236\end{array}$ & $\begin{array}{c}28 \\
0.237\end{array}$ & $\begin{array}{c}35 \\
0.211\end{array}$ & $\begin{array}{c}37 \\
0.405\end{array}$ & $\begin{array}{c}37 \\
0.209\end{array}$ & $\begin{array}{c}37 \\
0.209\end{array}$ & $\begin{array}{c}36 \\
0.436\end{array}$ & $\begin{array}{c}37 \\
0.381\end{array}$ & $\begin{array}{c}25 \\
0.359\end{array}$ & $\begin{array}{c}37 \\
0.439\end{array}$ & $\begin{array}{c}36 \\
0.468\end{array}$ & $\begin{array}{c}36 \\
0.490\end{array}$ & $\begin{array}{c}36 \\
0.219\end{array}$ & $\begin{array}{c}36 \\
0.212\end{array}$ \\
\hline
\end{tabular}

Note: Standard errors in parentheses are robust and clustered by country. *, **, *** indicate that coefficients are significant at 10,5 and 1 percent levels respectively. All regressions inlcude country and time fixed effects. 
Table A7. Manufacturing Exports Fixed Effects Regressions for Low-Income Countries

\begin{tabular}{|c|c|c|c|c|c|c|c|c|c|c|c|c|c|c|}
\hline & 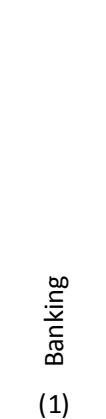 & 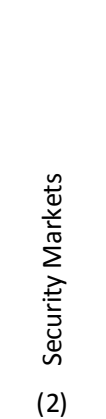 & 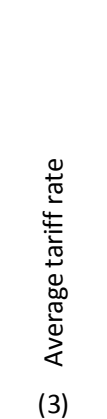 & 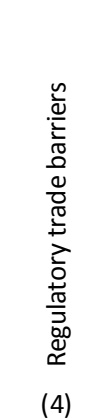 & 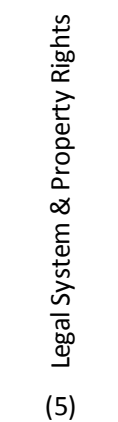 & 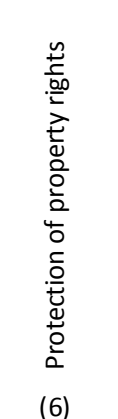 & 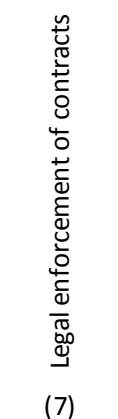 & 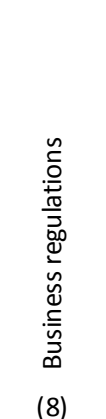 & 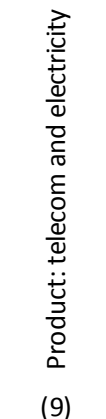 & 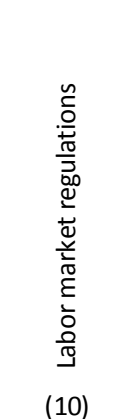 & 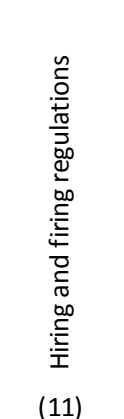 & 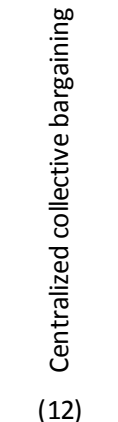 & 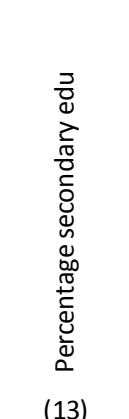 & 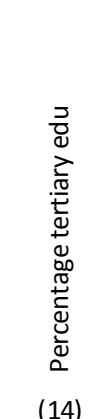 \\
\hline Lagged log change REER & $\begin{array}{c}0.235 \\
(0.379)\end{array}$ & $\begin{array}{c}0.455 \\
(0.459)\end{array}$ & $\begin{array}{c}0.108 \\
(1.662)\end{array}$ & $\begin{array}{c}2.876 \\
(1.900)\end{array}$ & $\begin{array}{l}-0.859 \\
(1.223)\end{array}$ & $\begin{array}{l}3.909^{* *} \\
(1.319)\end{array}$ & $\begin{array}{l}-0.497 \\
(3.904)\end{array}$ & $\begin{array}{l}5.448^{* *} \\
(2.197)\end{array}$ & $\begin{array}{l}0.848^{* *} \\
(0.296)\end{array}$ & $\begin{array}{c}-5.461 * * * \\
(1.770)\end{array}$ & $\begin{array}{c}-5.819^{* *} \\
(1.864)\end{array}$ & $\begin{array}{l}-2.204 \\
(3.216)\end{array}$ & $\begin{array}{l}0.0732 \\
(0.151)\end{array}$ & $\begin{array}{c}1.615^{* *} \\
(0.751)\end{array}$ \\
\hline Lagged structural indicator & $\begin{array}{l}0.759 * * \\
(0.244)\end{array}$ & $\begin{array}{l}0.381^{*} \\
(0.184)\end{array}$ & $\begin{array}{l}-1.424^{*} \\
(0.800)\end{array}$ & $\begin{array}{l}-0.0342 \\
(0.0323)\end{array}$ & $\begin{array}{l}-0.0250 \\
(0.0341)\end{array}$ & $\begin{array}{l}-0.0102- \\
(0.0893)\end{array}$ & $\begin{array}{c}-0.000749 \\
(0.0459)\end{array}$ & $\begin{array}{l}-0.0458 \\
(0.0700)\end{array}$ & $\begin{array}{l}-0.125 \\
(0.184)\end{array}$ & $\begin{array}{l}-0.0749 \\
(0.0820)\end{array}$ & $\begin{array}{c}-0.0595 \\
(0.0516)\end{array}$ & $\begin{array}{c}-0.102^{* *} \\
(0.0416)\end{array}$ & $\begin{array}{l}0.0244^{* *} \\
(0.00973)\end{array}$ & $\begin{array}{l}-0.0130 \\
(0.0251)\end{array}$ \\
\hline Lagged log change REER * Lagged structural indicator & $\begin{array}{l}1.506 * \\
(0.728)\end{array}$ & $\begin{array}{c}0.926 \\
(0.647)\end{array}$ & $\begin{array}{c}1.908 \\
(2.966)\end{array}$ & $\begin{array}{l}-0.267 \\
(0.447)\end{array}$ & $\begin{array}{c}0.573 \\
(0.390)\end{array}$ & $\begin{array}{l}-0.651 \\
(0.446)\end{array}$ & $\begin{array}{c}0.272 \\
(0.922)\end{array}$ & $\begin{array}{l}-0.795 \\
(0.554)\end{array}$ & $\begin{array}{c}3.007 \\
(1.709)\end{array}$ & $\begin{array}{c}1.011 * * * \\
(0.223)\end{array}$ & $\begin{array}{c}1.157^{* * *} \\
(0.347)\end{array}$ & $\begin{array}{c}0.506 \\
(0.501)\end{array}$ & $\begin{array}{c}0.00510 \\
(0.00856)\end{array}$ & $\begin{array}{c}-0.149 * \\
(0.0739)\end{array}$ \\
\hline Log change partner GDP & $\begin{array}{l}-28.37^{*} \\
(13.16)\end{array}$ & $\begin{array}{l}-20.86^{*} \\
(10.35)\end{array}$ & $\begin{array}{l}-18.93 \\
(25.55)\end{array}$ & $\begin{array}{l}-21.45 \\
(21.81)\end{array}$ & $\begin{array}{l}-10.03 \\
(11.44)\end{array}$ & $\begin{array}{l}-49.98 \\
(40.64)\end{array}$ & $\begin{array}{l}-45.45 \\
(30.81)\end{array}$ & $\begin{array}{l}-28.79 \\
(21.81)\end{array}$ & $\begin{array}{c}19.49 \\
(13.08)\end{array}$ & $\begin{array}{l}-15.15 \\
(15.15)\end{array}$ & $\begin{array}{l}-16.46 \\
(47.80)\end{array}$ & $\begin{array}{c}13.41 \\
(56.20)\end{array}$ & $\begin{array}{c}12.01 \\
(20.54)\end{array}$ & $\begin{array}{c}21.48 \\
(23.27)\end{array}$ \\
\hline Log change export deflator & $\begin{array}{l}-0.312 \\
(0.902)\end{array}$ & $\begin{array}{l}-0.335 \\
(0.781)\end{array}$ & $\begin{array}{l}-0.503 \\
(0.375)\end{array}$ & $\begin{array}{l}-0.621 \\
(0.392)\end{array}$ & $\begin{array}{l}-0.348 \\
(0.326)\end{array}$ & $\begin{array}{c}-0.723^{* *} \\
(0.324)\end{array}$ & $\begin{array}{l}-0.395 \\
(0.537)\end{array}$ & $\begin{array}{l}-0.422 \\
(0.449)\end{array}$ & $\begin{array}{l}-0.237 \\
(0.316)\end{array}$ & $\begin{array}{l}-0.768^{*} \\
(0.394)\end{array}$ & $\begin{array}{l}-1.287 \\
(0.736)\end{array}$ & $\begin{array}{l}-0.934^{*} \\
(0.424)\end{array}$ & $\begin{array}{l}-0.584 \\
(0.480)\end{array}$ & $\begin{array}{l}-0.567 \\
(0.421)\end{array}$ \\
\hline $\begin{array}{l}\text { Observations } \\
\text { Countries }\end{array}$ & $\begin{array}{c}41 \\
6\end{array}$ & $\begin{array}{c}41 \\
6\end{array}$ & $\begin{array}{l}76 \\
14\end{array}$ & $\begin{array}{l}39 \\
13\end{array}$ & $\begin{array}{l}87 \\
14\end{array}$ & $\begin{array}{l}33 \\
11\end{array}$ & $\begin{array}{l}37 \\
13\end{array}$ & $\begin{array}{l}39 \\
13\end{array}$ & $\begin{array}{l}66 \\
14\end{array}$ & $\begin{array}{l}39 \\
13\end{array}$ & $\begin{array}{l}30 \\
11\end{array}$ & $\begin{array}{l}30 \\
11\end{array}$ & $\begin{array}{c}107 \\
16\end{array}$ & $\begin{array}{c}107 \\
16\end{array}$ \\
\hline$R^{2}$ & 0.670 & 0.625 & 0.466 & 0.392 & 0.388 & 0.584 & 0.202 & 0.410 & 0.537 & 0.471 & 0.720 & 0.583 & 0.221 & 0.239 \\
\hline
\end{tabular}

Note: Standard errors in parentheses are robust and clustered by country. *, **, *** indicate that coefficients are significant at 10, 5 and 1 percent levels respectively. All regressions inlcude country and time fixed effects. 
Table A8. Services Exports Fixed Effects Regressions for Advanced Economies and Emerging Markets (Non-LICs)

\begin{tabular}{|c|c|c|c|c|c|c|c|c|c|c|c|c|c|c|}
\hline & 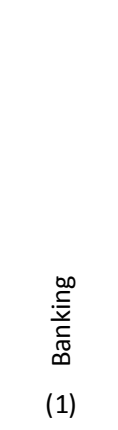 & 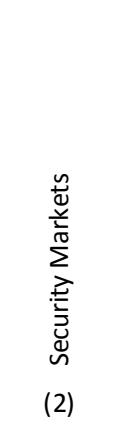 & 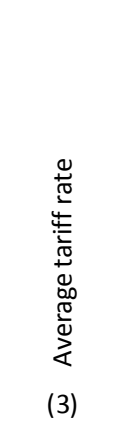 & 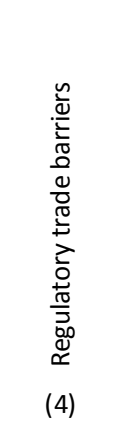 & 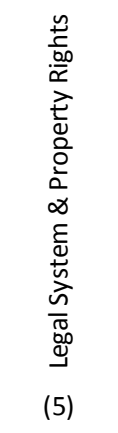 & 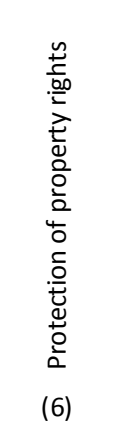 & 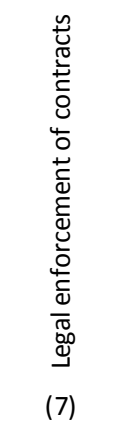 & 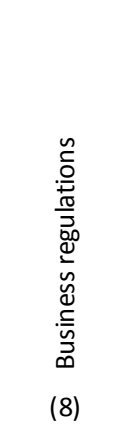 & 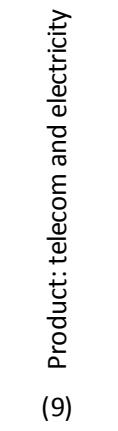 & 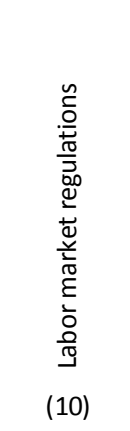 & 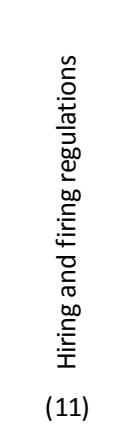 & 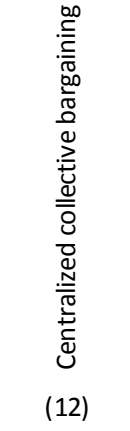 & 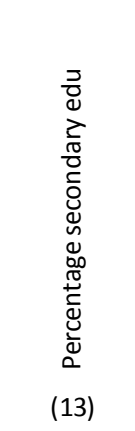 & 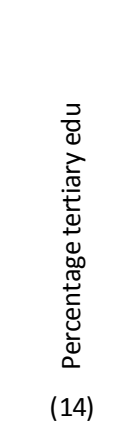 \\
\hline Lagged log change REER & $\begin{array}{c}-0.412 \\
(0.292)\end{array}$ & $\begin{array}{c}-0.450^{*} \\
(0.253)\end{array}$ & $\begin{array}{c}-1.016^{* * *} \\
(0.364)\end{array}$ & $\begin{array}{c}*-1.935^{* * *} \\
(0.592)\end{array}$ & $\begin{array}{l}-0.227 \\
(0.351)\end{array}$ & $\begin{array}{c}-0.982^{* *} \\
(0.488)\end{array}$ & $\begin{array}{c}-1.078^{* *} \\
(0.493)\end{array}$ & $\begin{array}{c}-1.102^{* *} \\
(0.469)\end{array}$ & $\begin{array}{l}0.0456 \\
(0.209)\end{array}$ & $\begin{array}{c}0.581 \\
(0.448)\end{array}$ & $\begin{array}{c}0.586 \\
(0.401)\end{array}$ & $\begin{array}{c}0.879 \\
(0.933)\end{array}$ & $\begin{array}{c}0.158 \\
(0.210)\end{array}$ & $\begin{array}{l}0.00277 \\
(0.134)\end{array}$ \\
\hline Lagged structural indicator & $\begin{array}{c}0.0593 \\
(0.0541)\end{array}$ & $\begin{array}{l}-0.0148 \\
(0.0393)\end{array}$ & $\begin{array}{c}-0.0892 \\
(0.0602)\end{array}$ & $\begin{array}{c}0.0139 \\
(0.0107)\end{array}$ & $\begin{array}{c}0.0131^{* *} \\
(0.00608)\end{array}$ & $\begin{array}{c}0.00154 \\
(0.00756)(\end{array}$ & $\begin{array}{c}0.0114 \\
(0.00981)\end{array}$ & $\begin{array}{l}0.00663 \\
(0.0131)\end{array}$ & $\begin{array}{l}0.00280 \\
(0.0289)\end{array}$ & $\begin{array}{c}-0.00624 \\
(0.00727)\end{array}$ & $\begin{array}{c}0.00144 \\
(0.00807)\end{array}$ & $\begin{array}{c}-0.00474 \\
(0.00513)\end{array}$ & $\begin{array}{c}0.000403 \\
(0.000689)\end{array}$ & $\begin{array}{r}-0.00155 \\
(0.00207)\end{array}$ \\
\hline Lagged log change REER * Lagged structural indicator & $\begin{array}{c}0.914 * * \\
(0.378)\end{array}$ & $\begin{array}{c}0.876 * * * \\
(0.283)\end{array}$ & $\begin{array}{c}1.437 * * \\
(0.618)\end{array}$ & $\begin{array}{c}0.320 * * * \\
(0.0927)\end{array}$ & $\begin{array}{c}0.0427 \\
(0.0738)\end{array}$ & $\begin{array}{l}0.205^{* *} \\
(0.0822)\end{array}$ & $\begin{array}{c}0.208 * * \\
(0.0927)\end{array}$ & $\begin{array}{c}0.212^{* *} \\
(0.0870)\end{array}$ & $\begin{array}{c}0.147 \\
(0.398)\end{array}$ & $\begin{array}{c}-0.105 \\
(0.0926)\end{array}$ & $\begin{array}{c}-0.134 \\
(0.0993)\end{array}$ & $\begin{array}{l}-0.116 \\
(0.156)\end{array}$ & $\begin{array}{l}-0.00529 \\
(0.00644)\end{array}$ & $\begin{array}{r}-0.00312 \\
(0.0110)\end{array}$ \\
\hline Log change partner GDP & $\begin{array}{l}12.12^{* *} \\
(4.729)\end{array}$ & $\begin{array}{l}12.74^{* *} \\
(4.925)\end{array}$ & $\begin{array}{l}12.75^{* *} \\
(4.998)\end{array}$ & $\begin{array}{l}8.627^{*} \\
(4.691)\end{array}$ & $\begin{array}{l}9.958^{* *} \\
(3.991)\end{array}$ & $\begin{array}{l}12.15^{*} \\
(6.537)\end{array}$ & $\begin{array}{c}6.263 \\
(6.861)\end{array}$ & $\begin{array}{c}15.69^{* * *} \\
(5.788)\end{array}$ & $\begin{array}{c}13.74 \\
(9.159)\end{array}$ & $\begin{array}{l}15.22^{* *} \\
(6.326)\end{array}$ & $\begin{array}{l}17.73^{* *} \\
(6.911)\end{array}$ & $\begin{array}{l}14.07^{* *} \\
(6.685)\end{array}$ & $\begin{array}{l}10.49 * * \\
(4.372)\end{array}$ & $\begin{array}{l}10.17^{* *} \\
(4.645)\end{array}$ \\
\hline Log change export deflator & $\begin{array}{c}0.127 \\
(0.249)\end{array}$ & $\begin{array}{c}0.152 \\
(0.257)\end{array}$ & $\begin{array}{l}0.0965 \\
(0.224)\end{array}$ & $\begin{array}{c}0.473^{* * *} \\
(0.167)\end{array}$ & $\begin{array}{c}0.307 \\
(0.215)\end{array}$ & $\begin{array}{c}0.472^{* *} \\
(0.201)\end{array}$ & $\begin{array}{c}0.0496 \\
(0.373)\end{array}$ & $\begin{array}{c}0.251 \\
(0.221)\end{array}$ & $\begin{array}{c}0.472^{* *} \\
(0.199)\end{array}$ & $\begin{array}{l}0.371^{*} \\
(0.192)\end{array}$ & $\begin{array}{c}0.270 \\
(0.165)\end{array}$ & $\begin{array}{c}0.458^{* *} \\
(0.182)\end{array}$ & $\begin{array}{l}0.344^{*} \\
(0.194)\end{array}$ & $\begin{array}{l}0.331^{*} \\
(0.193)\end{array}$ \\
\hline Observations & 341 & 341 & 375 & 231 & 437 & 227 & 158 & 266 & 276 & 342 & 286 & 355 & 454 & 454 \\
\hline Countries & 44 & 44 & 51 & 54 & 54 & 53 & 54 & 54 & 41 & 54 & 53 & 53 & 54 & 54 \\
\hline $\mathrm{R}^{2}$ & 0.276 & 0.276 & 0.267 & 0.501 & 0.249 & 0.466 & 0.439 & 0.394 & 0.313 & 0.356 & 0.387 & 0.348 & 0.252 & 0.251 \\
\hline
\end{tabular}

Note: Standard errors in parentheses are robust and clustered by country. *, **, *** indicate that coefficients are significant at 10, 5 and 1 percent levels respectively. All regressions inlcude country and time fixed effects. 
Table A9. Summary Results for Expanded Set of Structural Variables

\begin{tabular}{|c|c|c|c|c|c|}
\hline & \multicolumn{4}{|c|}{ Manufacturing } & \multirow{2}{*}{$\frac{\text { Services }}{\text { Non-LIC }}$} \\
\hline & NonLIC & AM & EM & LIC & \\
\hline \multicolumn{6}{|l|}{ Financial sector } \\
\hline Banking & - & + & - & $+*$ & $+\star \star$ \\
\hline Interest rate controls & - & + & - & $+* *$ & + \\
\hline Directed credit/reserve requirements & - & $+^{*}$ & - & + & 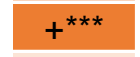 \\
\hline Privatization & - & + & - & + & + \\
\hline Banking Supervision & + & + & + & $+* \star$ & $+*$ \\
\hline Security Markets & - & $+\star \star \star$ & - & + & 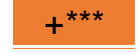 \\
\hline \multicolumn{6}{|l|}{ Openness } \\
\hline Tariff Rates (average) & - & + & - & + & 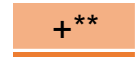 \\
\hline Regulatory trade barriers & + & + & - & - & $+* \star *$ \\
\hline Restrictions on current account transactions & $-{ }^{\star}$ & + & $-^{\star}$ & + & $+^{*}$ \\
\hline Restrictions on capital account transactions & - & + & - & + & $+*$ \\
\hline \multicolumn{6}{|l|}{ Institutions } \\
\hline Legal System \& Property Rights & - & $+* \star$ & - & + & + \\
\hline Protection of property rights & $+* \star \star$ & + & $+* *$ & - & $+* \star$ \\
\hline Legal enforcement of contracts & + & - & + & + & $+* *$ \\
\hline \multicolumn{6}{|l|}{ Product market regulation } \\
\hline Business regulations & + & $+* \star$ & + & - & $+* \star$ \\
\hline Product: telecom and electricity & $-{ }^{\star}$ & + & - & + & + \\
\hline \multicolumn{6}{|l|}{ Infrastructure } \\
\hline Electricity production capacity & + & + & - & $--^{\star \star \star}$ & + \\
\hline Telephone lines & + & + & - & 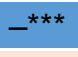 & + \\
\hline Roads density & - & + & - & + & + \\
\hline \multicolumn{6}{|l|}{ Labor } \\
\hline Labor market regulations & + & $+^{*}$ & - & $+* \star \star *$ & - \\
\hline Hiring and firing regulations & + & $+* \star$ & + & $+* * *$ & - \\
\hline Centralized collective bargaining & + & + & + & + & - \\
\hline \multicolumn{6}{|l|}{ Human capital and R\&D } \\
\hline Percentage of secondary & $+*$ & - & $+* *$ & + & - \\
\hline Percentage of tertiary & + & $+^{*}$ & - & $-{ }^{*}$ & - \\
\hline Basic R\&D spending & + & + & - & & - \\
\hline
\end{tabular}

Note: Table shows the sign on the interaction term between the lagged log change in REER and the lagged structural indicator. *,**, *** indicate that coefficients are significant at 10, 5 and 1 percent levels respectively. All regressions inlcude country and time fixed effects. 
Table A10. Summary of Results Using Alternative Measures of REER, Non-LICs only

\begin{tabular}{|c|c|c|c|c|c|c|}
\hline & \multicolumn{3}{|c|}{ Manufacturing } & \multicolumn{3}{|c|}{ Services } \\
\hline & CPI & ULC & PPP & CPI & ULC & PPP \\
\hline \multicolumn{7}{|l|}{ Financial sector } \\
\hline Banking & - & + & - & $+* *$ & $+\star \star$ & - \\
\hline Security Markets & - & + & - & $+* * *$ & $+\star \star \star *$ & - \\
\hline \multicolumn{7}{|l|}{ Openness } \\
\hline Tariff Rates (average) & - & + & - & $+* *$ & 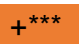 & - \\
\hline Regulatory trade barriers & + & + & - & $+* \star \star$ & + & $+* \star$ \\
\hline \multicolumn{7}{|l|}{ Institutions } \\
\hline Protection of property rights & $+* \star \star$ & + & + & $+{ }^{* \star}$ & $+*$ & $+\star \star *$ \\
\hline Legal enforcement of contracts & + & + & $+^{*}$ & $+* *$ & + & + \\
\hline \multicolumn{7}{|l|}{ Product market regulation } \\
\hline Business regulations & + & + & - & $+* \star$ & + & + \\
\hline Product: telecom and electricity & $-^{*}$ & - & - & + & + & - \\
\hline \multicolumn{7}{|l|}{ Labor } \\
\hline Hiring and firing regulations & + & $+* \star$ & $+* *$ & - & - & - \\
\hline Centralized collective bargaining & + & $+* \star$ & + & - & + & - \\
\hline \multicolumn{7}{|l|}{ Human capital and R\&D } \\
\hline Percentage of secondary & $+^{*}$ & $-\star \star \star *$ & + & - & - & - \\
\hline Percentage of tertiary & + & + & + & - & + & - \\
\hline Basic R\&D spending & + & $-^{*}$ & - & - & $-\star \star$ & - \\
\hline
\end{tabular}

Note: Table shows the sign on the interaction term between the lagged log change in REER and the lagged structural indicator. *, **, *** indicate that coefficients are significant at 10, 5 and 1 percent levels respectively. All regressions inlcude country and time fixed effects.

The “CPI” column presents main results (identical to Table 7) for easy comparison. 
Table A11. Summary of Results Using Annual Data

\begin{tabular}{|c|c|c|c|c|c|c|c|c|c|c|c|c|}
\hline & \multicolumn{10}{|c|}{ Manufacturing exports } & \multirow{2}{*}{\multicolumn{2}{|c|}{$\begin{array}{c}\text { Services } \\
\text { Non-LICs }\end{array}$}} \\
\hline & \multicolumn{2}{|c|}{ All countries } & \multicolumn{2}{|c|}{ Non-LICs } & \multicolumn{2}{|c|}{ AEs } & \multicolumn{2}{|c|}{ EMs } & \multicolumn{2}{|c|}{ LICs } & & \\
\hline & 1 year & 3 years & 1 year & 3 years & 1 year & 3 years & 1 year & 3 years & 1 year & 3 years & 1 year & 3 years \\
\hline \multicolumn{13}{|l|}{ Financial sector } \\
\hline Banking & $-^{*}$ & + & - & - & + & + & - & - & - & $+^{*}$ & $-{ }^{\star *}$ & $+* *$ \\
\hline Security Markets & - & + & - & - & - & $+* *$ & + & - & + & + & - & $+* \star \star$ \\
\hline \multicolumn{13}{|l|}{ Openness } \\
\hline Tariff Rates (average) & $-^{*}$ & - & - & - & + & + & - & - & $-^{*}$ & + & + & $+{ }^{\star *}$ \\
\hline Regulatory trade barriers & - & $-^{*}$ & + & + & - & + & + & - & - & - & $+^{*}$ & $+* \star \star$ \\
\hline \multicolumn{13}{|l|}{ Institutions } \\
\hline Protection of property rights & + & - & + & $+* \star \star$ & $-{ }^{* *}$ & + & + & $+* *$ & + & - & $+* *$ & $+* *$ \\
\hline Legal enforcement of contracts & - & + & $+* \star \star$ & + & - & - & $+* * *$ & + & - & + & $+* *$ & $+* *$ \\
\hline \multicolumn{13}{|l|}{ Product market regulation } \\
\hline Business regulations & + & - & + & + & + & $+{ }^{* *}$ & + & + & + & - & $+{ }^{*}$ & $+* \star$ \\
\hline Product: telecom and electricity & - & - & - & $-^{*}$ & - & + & - & - & - & + & + & + \\
\hline \multicolumn{13}{|l|}{ Labor } \\
\hline Hiring and firing regulations & $+{ }^{*}$ & $+* \star *$ & 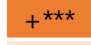 & + & + & $+* *$ & $+* * *$ & + & + & $+* \star \star$ & + & - \\
\hline Centralized collective bargaining & + & $+^{*}$ & + & + & $-{ }^{* \star}$ & + & + & + & + & + & - & - \\
\hline \multicolumn{13}{|l|}{ Human capital and R\&D } \\
\hline Percentage of secondary & + & $+{ }^{*}$ & - & $+{ }^{*}$ & $-{ }^{* \star}$ & - & + & $+* \star$ & - & + & $-{ }^{\star \star \star}$ & - \\
\hline Percentage of tertiary & - & - & - & + & $-^{*}$ & $+^{*}$ & - & - & - & $-^{*}$ & $-{ }^{* * *}$ & - \\
\hline Basic R\&D spending & $-^{*}$ & + & $-^{*}$ & + & 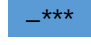 & + & $-{ }^{* \star *}$ & - & & & + & - \\
\hline
\end{tabular}

Note: Table shows the sign on the interaction term between the lagged log change in REER and the lagged structural indicator. *, **, *** indicate that coefficients are significant at 10, 5 and 1 percent levels respectively. All regressions inlcude country and time fixed effects.

The “3 year” column presents main results (identical to Table 7) for easy comparison. 
Table A12. Baseline Regressions with ECI for Manufacturing Exports

\begin{tabular}{|c|c|c|c|c|c|c|c|c|c|}
\hline & \multicolumn{3}{|c|}{ Non-LICs } & \multicolumn{3}{|c|}{ Advanced Economies } & \multicolumn{3}{|c|}{ Emerging Markets } \\
\hline & (1) & (2) & (3) & (4) & (5) & (6) & (7) & (8) & (9) \\
\hline Lagged log change REER & $\begin{array}{l}0.181^{* \star *} \\
(0.0666)\end{array}$ & $\begin{array}{l}0.191^{* \star *} \\
(0.0699)\end{array}$ & $\begin{array}{l}0.209^{* * *} \\
(0.0742)\end{array}$ & $\begin{array}{l}0.336^{\star \star *} \\
(0.0814)\end{array}$ & $\begin{array}{l}0.330^{\star \star} \\
(0.143)\end{array}$ & $\begin{array}{l}0.331^{\star *} \\
(0.144)\end{array}$ & $\begin{array}{c}0.152^{*} \\
(0.0862)\end{array}$ & $\begin{array}{c}0.114 \\
(0.0898)\end{array}$ & $\begin{array}{c}0.117 \\
(0.101)\end{array}$ \\
\hline Log change partner GDP & $\begin{array}{l}9.344^{\star *} \\
(3.641)\end{array}$ & $\begin{array}{l}9.571^{* \star} \\
(3.676)\end{array}$ & $\begin{array}{l}9.245^{\star *} \\
(3.704)\end{array}$ & $\begin{array}{l}7.864^{\star \star} \\
(2.837)\end{array}$ & $\begin{array}{l}7.862^{\star \star} \\
(2.851)\end{array}$ & $\begin{array}{l}7.838^{\star *} \\
(2.833)\end{array}$ & $\begin{array}{l}9.774^{\star} \\
(5.227)\end{array}$ & $\begin{array}{c}10.32^{*} \\
(5.305)\end{array}$ & $\begin{array}{l}10.06^{*} \\
(5.267)\end{array}$ \\
\hline Log change export deflator & $\begin{array}{c}0.0394 \\
(0.0921)\end{array}$ & $\begin{array}{c}0.0390 \\
(0.0917)\end{array}$ & $\begin{array}{c}0.0472 \\
(0.0913)\end{array}$ & $\begin{array}{c}0.162^{\star} \\
(0.0890)\end{array}$ & $\begin{array}{c}0.162^{*} \\
(0.0895)\end{array}$ & $\begin{array}{c}0.162^{*} \\
(0.0902)\end{array}$ & $\begin{array}{l}0.0223 \\
(0.115)\end{array}$ & $\begin{array}{c}0.00919 \\
(0.117)\end{array}$ & $\begin{array}{l}0.0218 \\
(0.120)\end{array}$ \\
\hline Lagged ECI & $\begin{array}{l}-0.0378^{*} \\
(0.0201)\end{array}$ & $\begin{array}{l}-0.0372^{\star} \\
(0.0201)\end{array}$ & $\begin{array}{l}-0.0370^{*} \\
(0.0199)\end{array}$ & $\begin{array}{l}-0.0126 \\
(0.0248)\end{array}$ & $\begin{array}{l}-0.0126 \\
(0.0249)\end{array}$ & $\begin{array}{l}-0.0122 \\
(0.0234)\end{array}$ & $\begin{array}{l}-0.0403 \\
(0.0244)\end{array}$ & $\begin{array}{l}-0.0378 \\
(0.0244)\end{array}$ & $\begin{array}{l}-0.0383 \\
(0.0243)\end{array}$ \\
\hline Lagged ECI * Lagged log change REER & & $\begin{array}{l}-0.0810 \\
(0.0851)\end{array}$ & $\begin{array}{l}-0.0806 \\
(0.0852)\end{array}$ & & $\begin{array}{l}0.00356 \\
(0.0672)\end{array}$ & $\begin{array}{l}0.00386 \\
(0.0664)\end{array}$ & & $\begin{array}{l}-0.257^{*} \\
(0.152)\end{array}$ & $\begin{array}{l}-0.259 \\
(0.155)\end{array}$ \\
\hline Lagged GDP/capita, PPP & & & $\begin{array}{c}0.00148 \\
(0.00241)\end{array}$ & & & $\begin{array}{c}-0.000998 \\
(0.0114)\end{array}$ & & & $\begin{array}{c}0.00162 \\
(0.00280)\end{array}$ \\
\hline Observations & 494 & 494 & 488 & 202 & 202 & 202 & 292 & 292 & 286 \\
\hline Countries & 58 & 58 & 58 & 21 & 21 & 21 & 37 & 37 & 37 \\
\hline$R^{2}$ & 0.258 & 0.260 & 0.267 & 0.709 & 0.709 & 0.709 & 0.201 & 0.209 & 0.217 \\
\hline
\end{tabular}

Note: Standard errors in parentheses are robust and clustered by country. ${ }^{*}, * *, * * *$ indicate that coefficients are significant at 10, 5 and 1 percent levels respectively. All regressions inlcude country and time fixed effects. 
Figure A1. Elasticity of Manufacturing Exports w.r.t. REER. Non-LICs
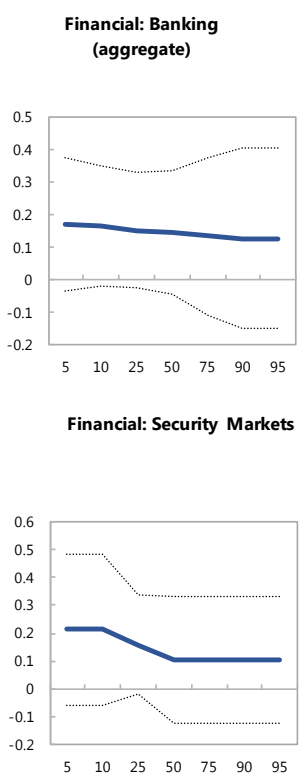

Restrictions on capital account transactions

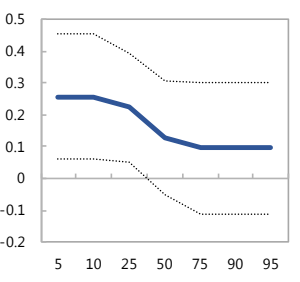

Product: telecom and electricity

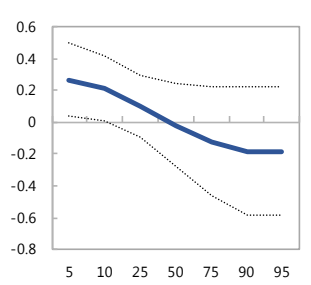

Hiring and firing regulations

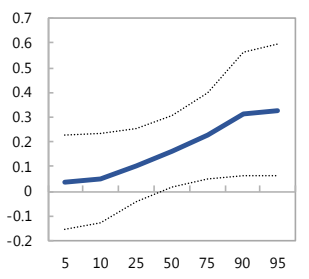

Financial: Interest rate controls

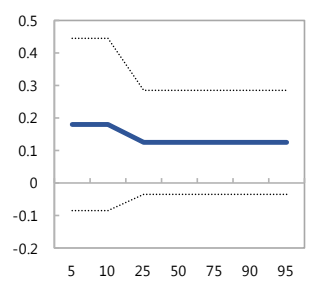

Tariff Rates (average)

Financial: Directed
credit/reserve requirements

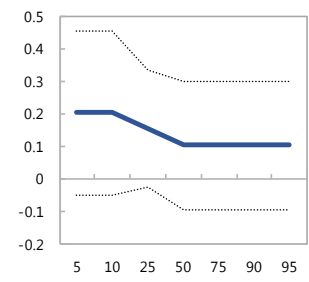

Mean tariff rate

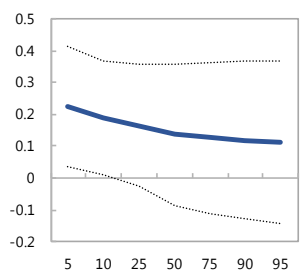

Legal System \& Property Rights

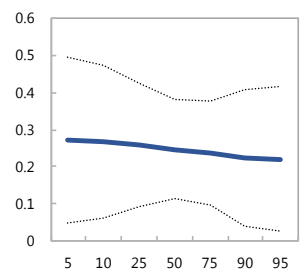

Electricity production

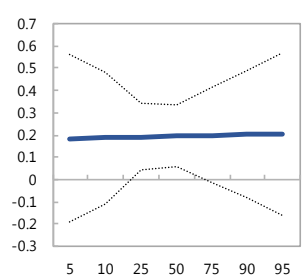

Centralized collective bargaining
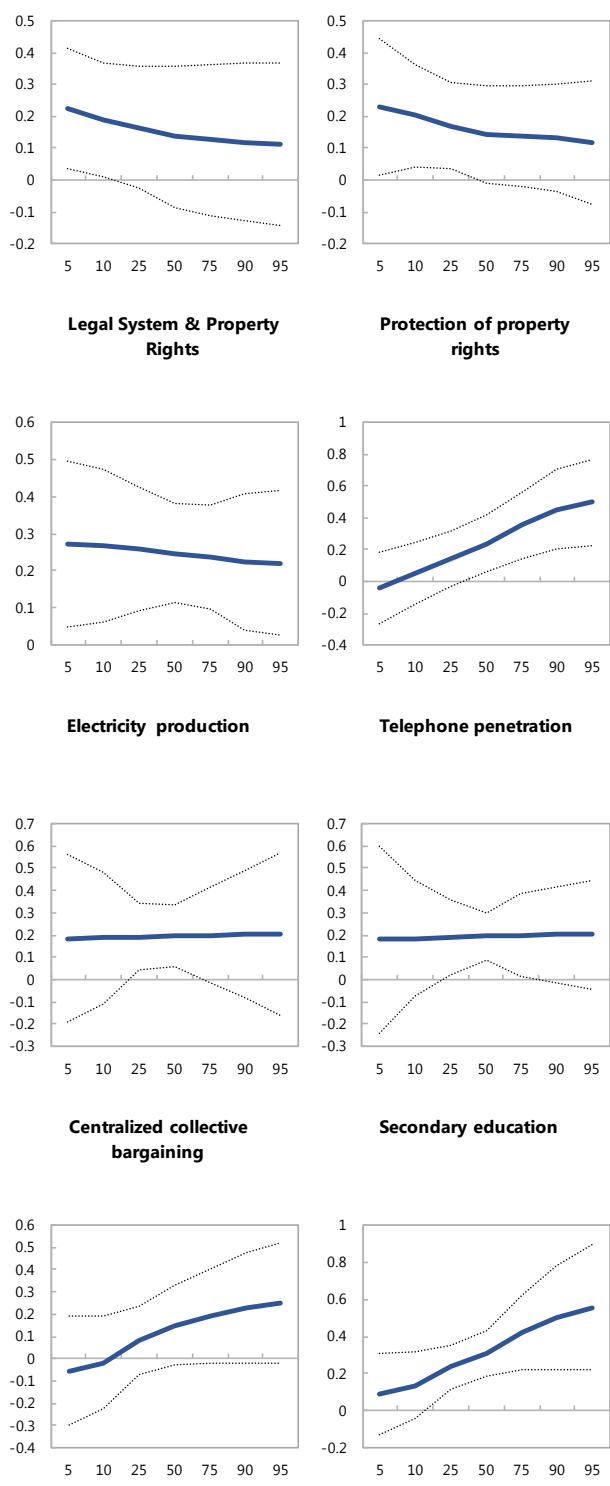

Protection of property rights

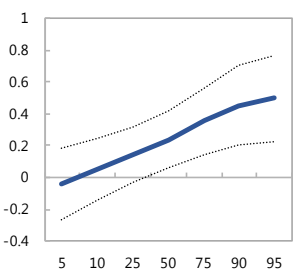

Telephone penetration

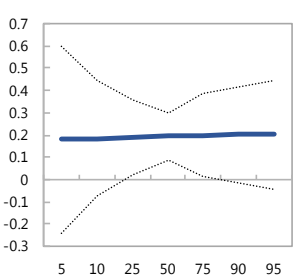

Secondary education

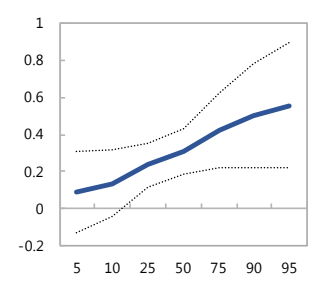

Financial: Privatization

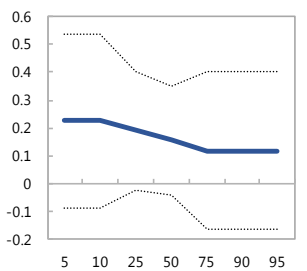

Regulatory trade barriers Financial: Banking
Supervision

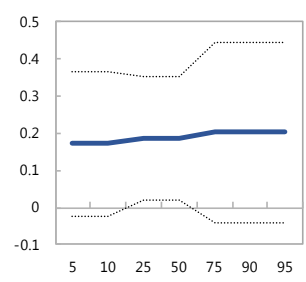

Financial restrictions on current account transactions

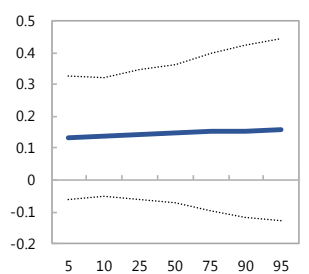
Legal enforcement of
contracts

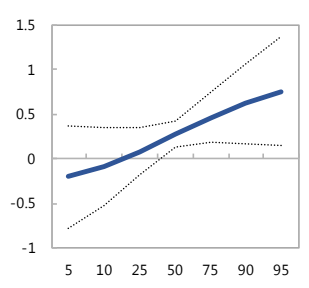

Road density

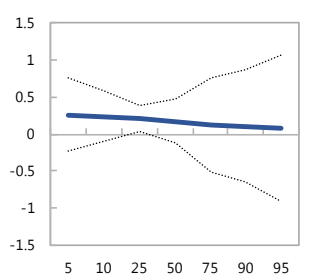

Tertiary education

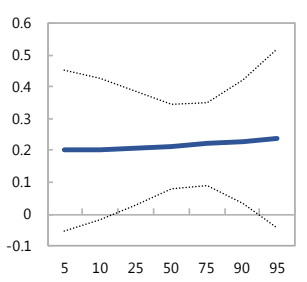

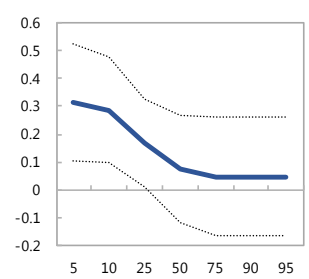

Business regulations

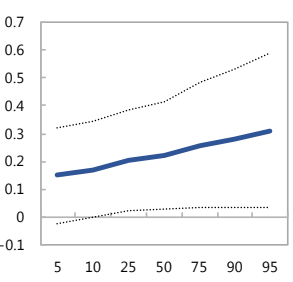

Labor market regulations

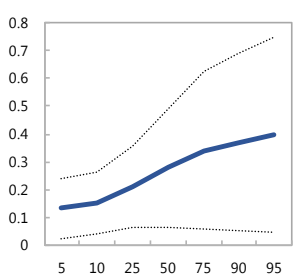

Basic R\&D spending

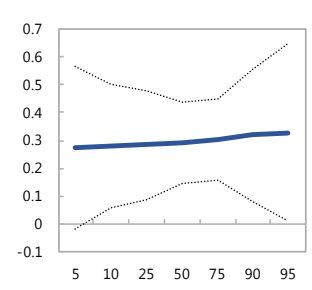


Figure A2. Elasticity of Manufacturing Exports w.r.t. REER. Advanced Economies

Financial: Banking

(aggregate)

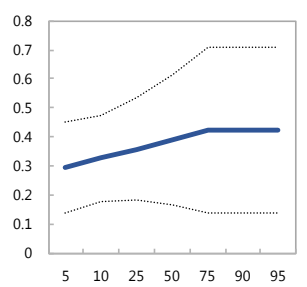

Financial: Security Markets

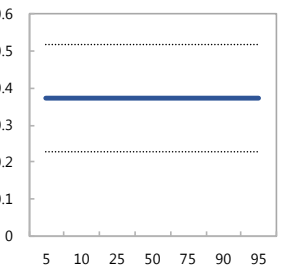

Restrictions on capital account transactions

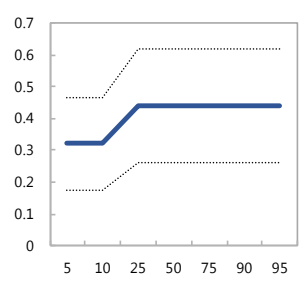

Product: telecom and electricity

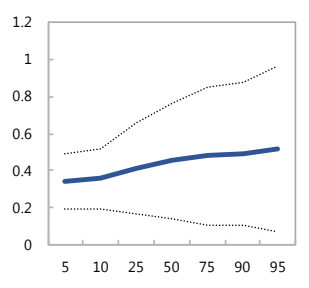

Hiring and firing regulations

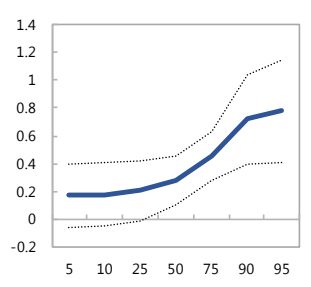

Financial: Interest rate controls

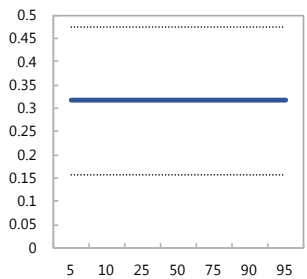

Tariff Rates (average)

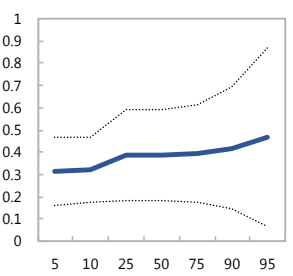

Legal System \& Property Rights

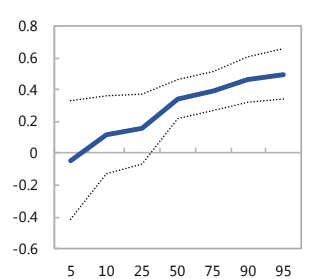

Electricity production
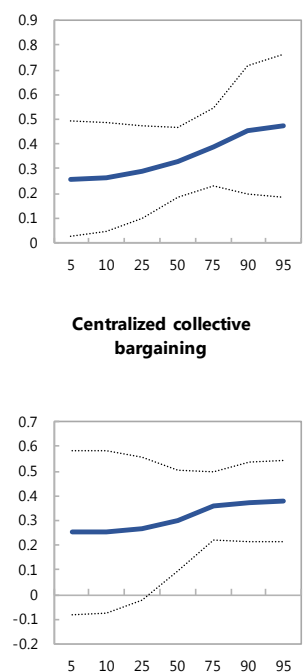

Financial: Directed credit/reserve requirements

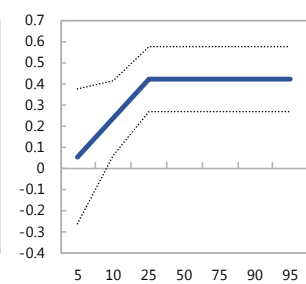

Mean tariff rate

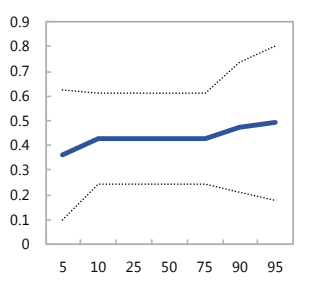

Protection of property rights

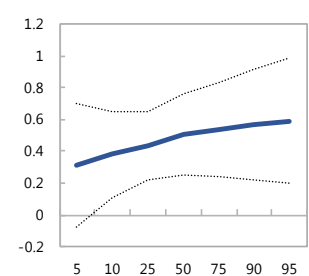

Telephone penetration

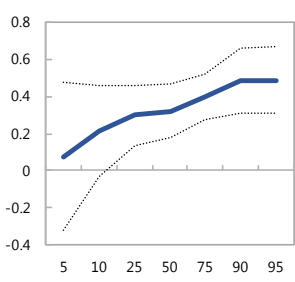

Secondary education

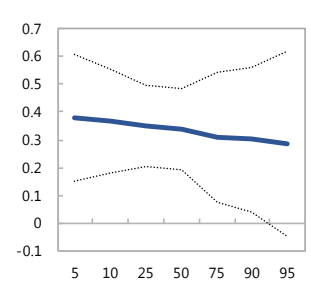

Financial: Privatization

Financial: Banking
Supervision

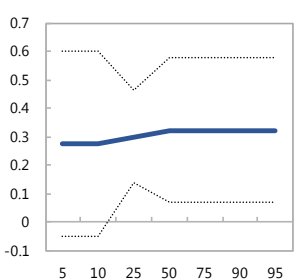

Regulatory trade barriers

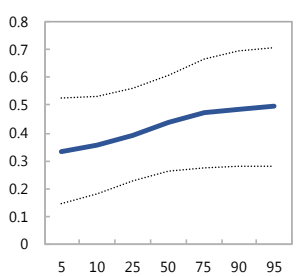

Legal enforcement of contracts

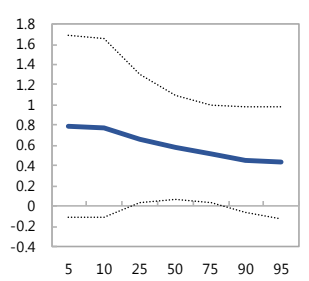

Road density

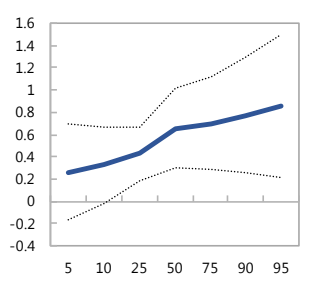

Tertiary education

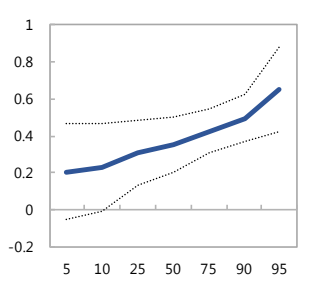

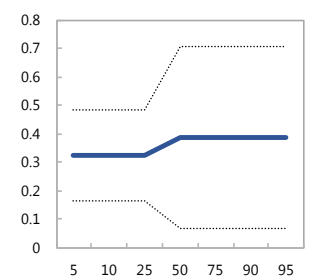

Financial restrictions on current account transactions

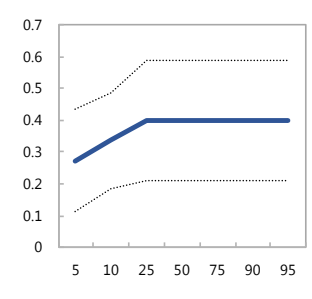

Business regulations

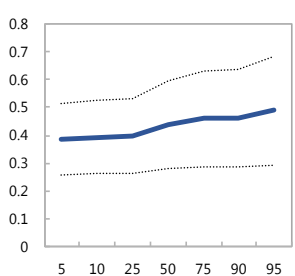

Labor market regulations
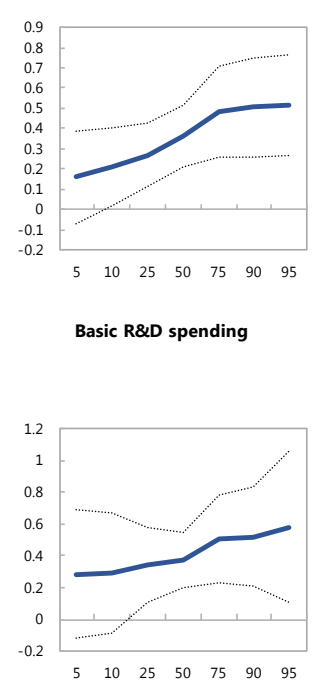
Figure A3. Elasticity of Manufacturing Exports w.r.t. REER. Emerging Markets

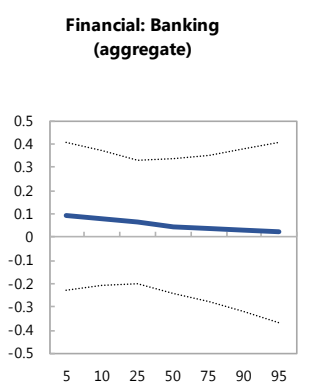

Financial: Interest rate

Product: telecom and electricity

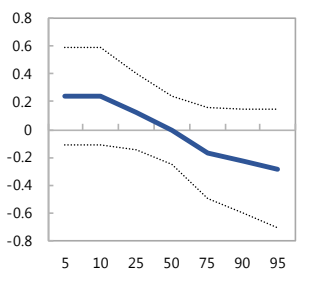

Hiring and firing regulations

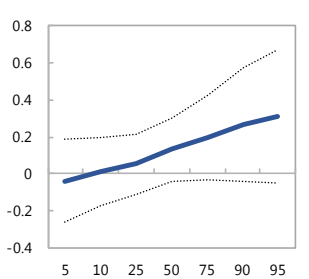
controls

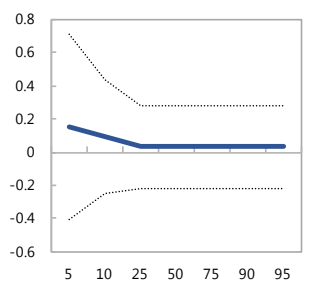

Tariff Rates (average)

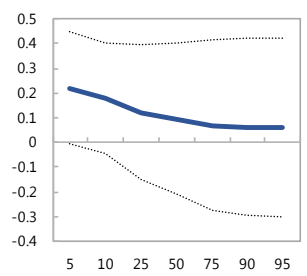

Legal System \& Property Rights

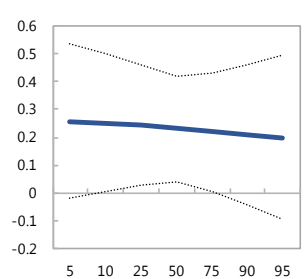

Electricity production

Financial: Directed
credit/reserve requirements

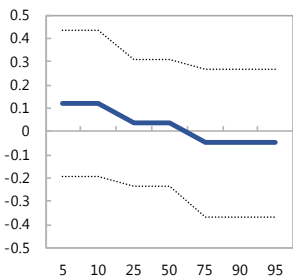

Mean tariff rate

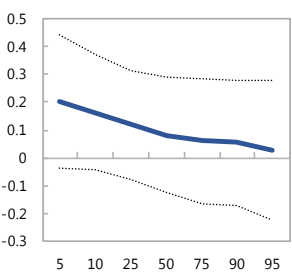

Protection of property rights

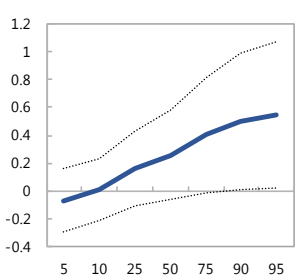

Telephone penetration

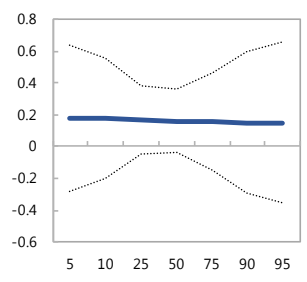

Centralized collective bargaining
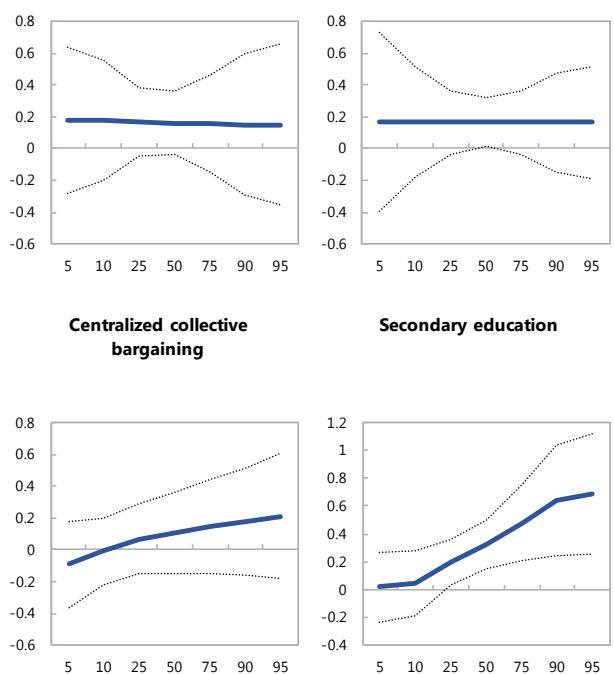

Secondary education

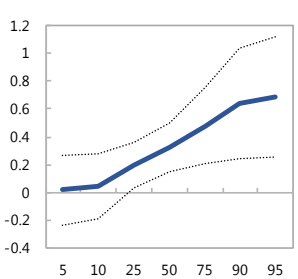

Financial: Privatization

Financial: Banking
Supervision

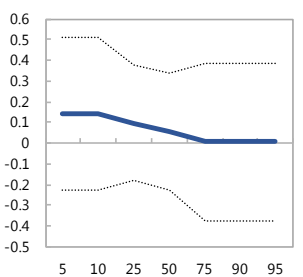

Regulatory trade barriers

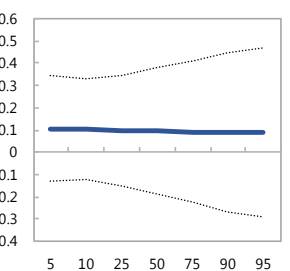

Legal enforcement of contracts

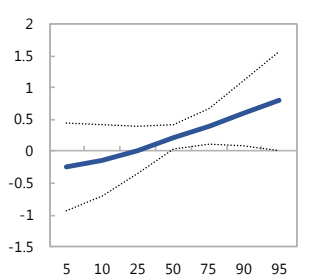

Road density

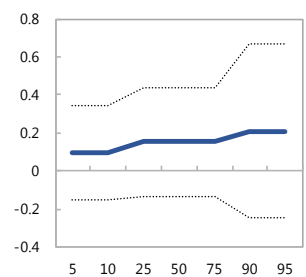

Financial restrictions on current account transactions

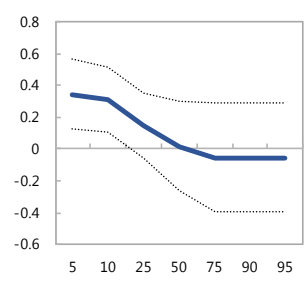

Business regulations

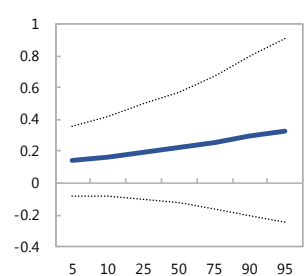

Labor market regulations

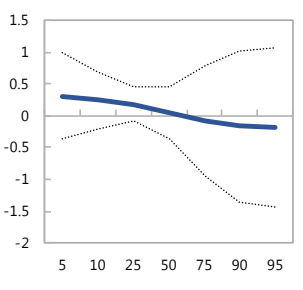

Tertiary education

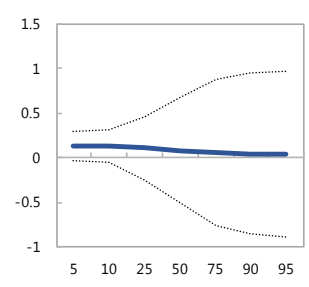

Basic R\&D spending
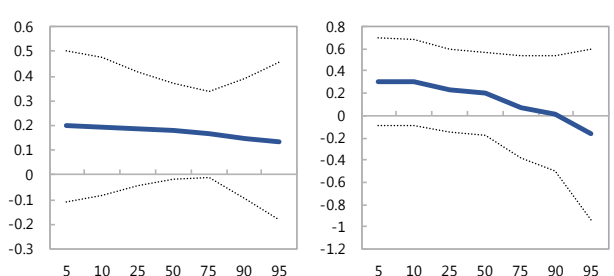
Figure A4. Elasticity of Manufacturing Exports w.r.t. REER. Low Income Countries

Financial: Banking

(aggregate)

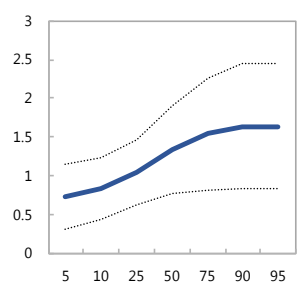

Financial: Security Markets

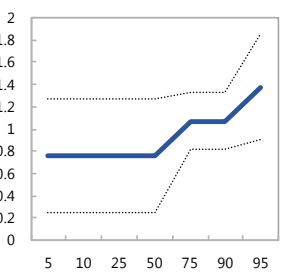

Restrictions on capital account transactions

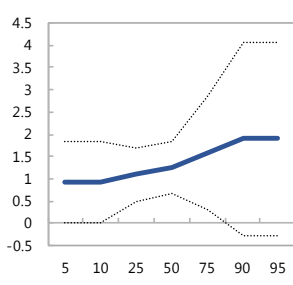

Product: telecom and electricity

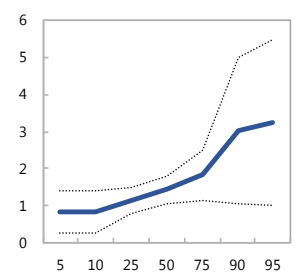

Hiring and firing regulations

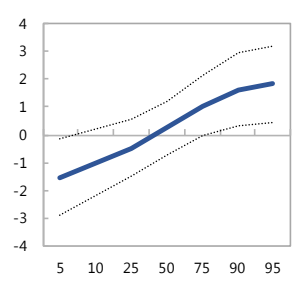

Financial: Interest rate controls

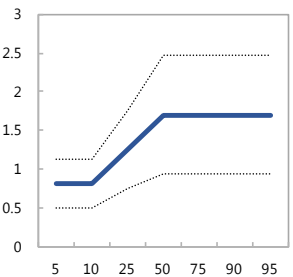

Tariff Rates (average)

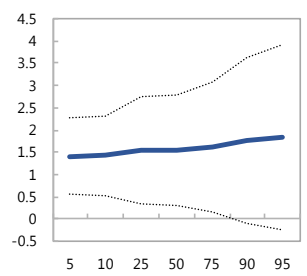

Legal System \& Property Rights

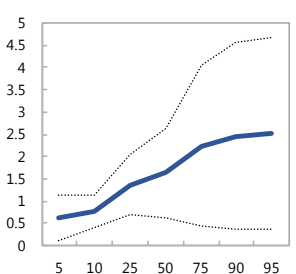

Electricity production
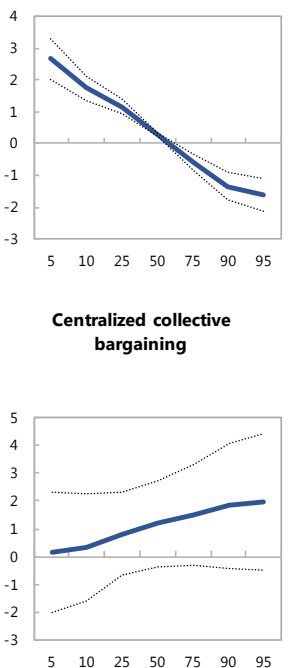

Financial: Directed credit/reserve requirements

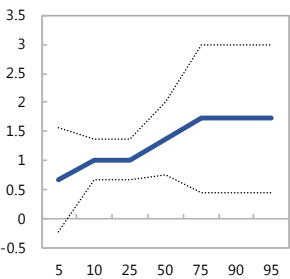

Mean tariff rate

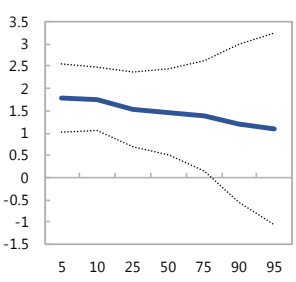

Protection of property rights

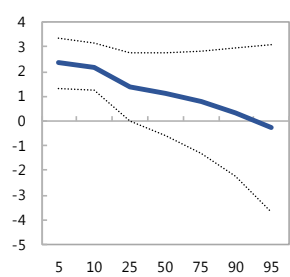

Telephone penetration

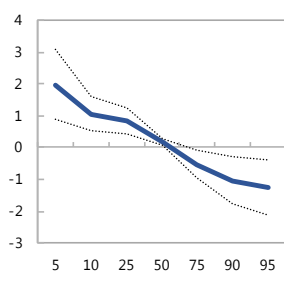

Secondary education

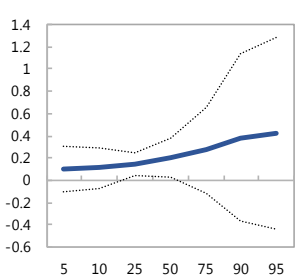

Financial: Privatization

Financial: Banking Supervision

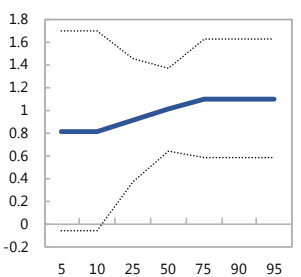

Regulatory trade barriers
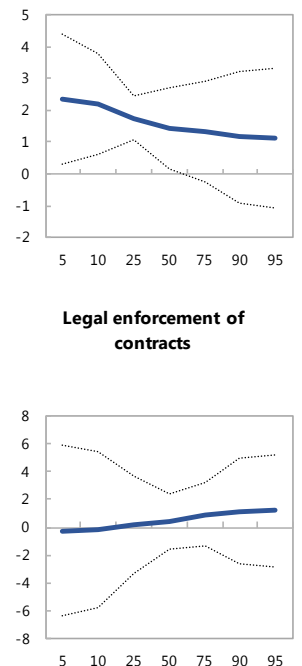

Road density

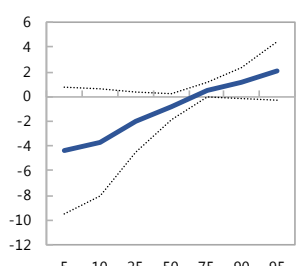

Tertiary education

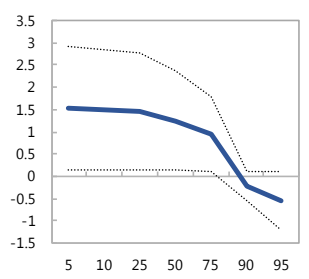

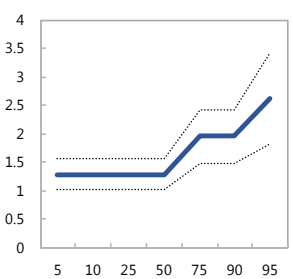

Financial restrictions on current account transactions

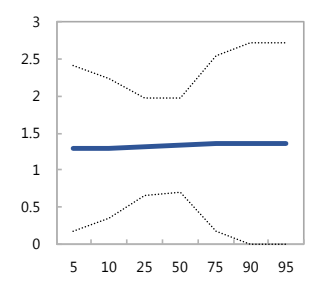

Business regulations

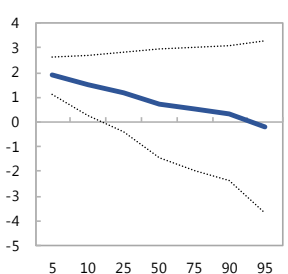

Labor market regulations

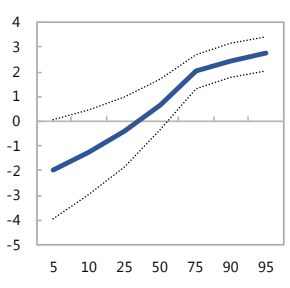


Figure A5. Elasticity of Services Exports w.r.t. REER. Non-LICs

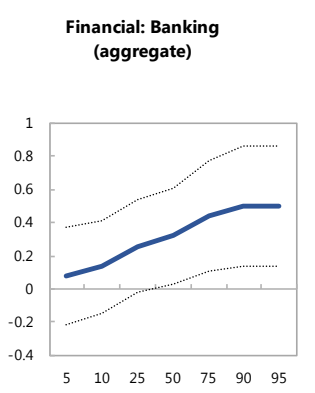

$$
\begin{aligned}
& \text { Financial: Interest rate } \\
& \text { controls }
\end{aligned}
$$
Financial: Directed credit/reserve
requirements

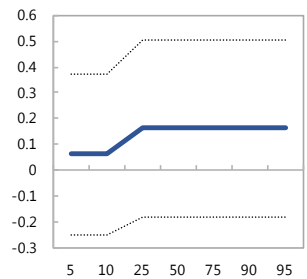

Financial: Security Markets

Tariff Rates (average)

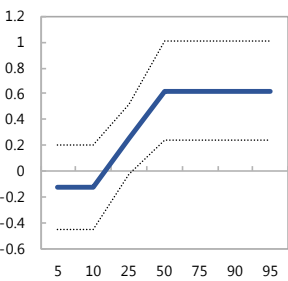

Mean tariff rate
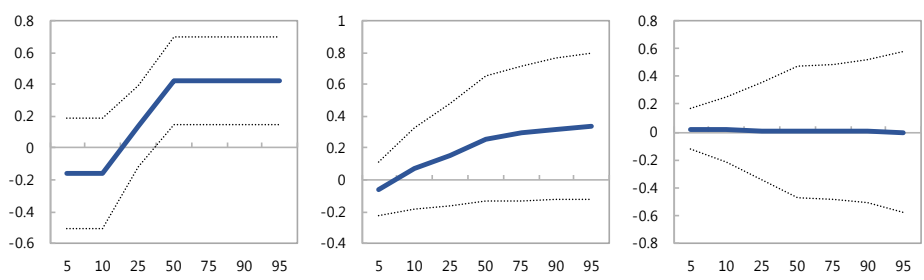

Restrictions on capital account transactions

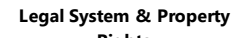
Rights

Protection of property rights

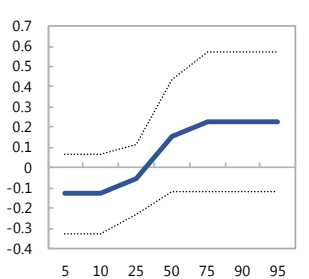

Product: telecom and electricity
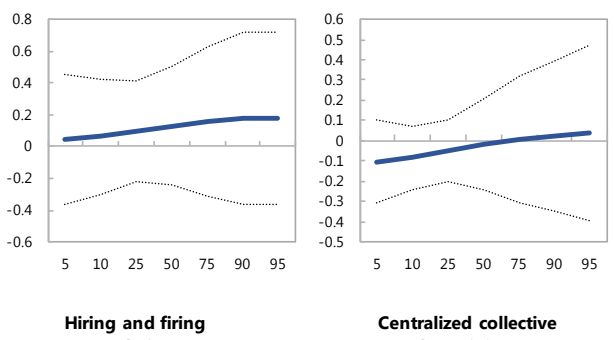
regulations
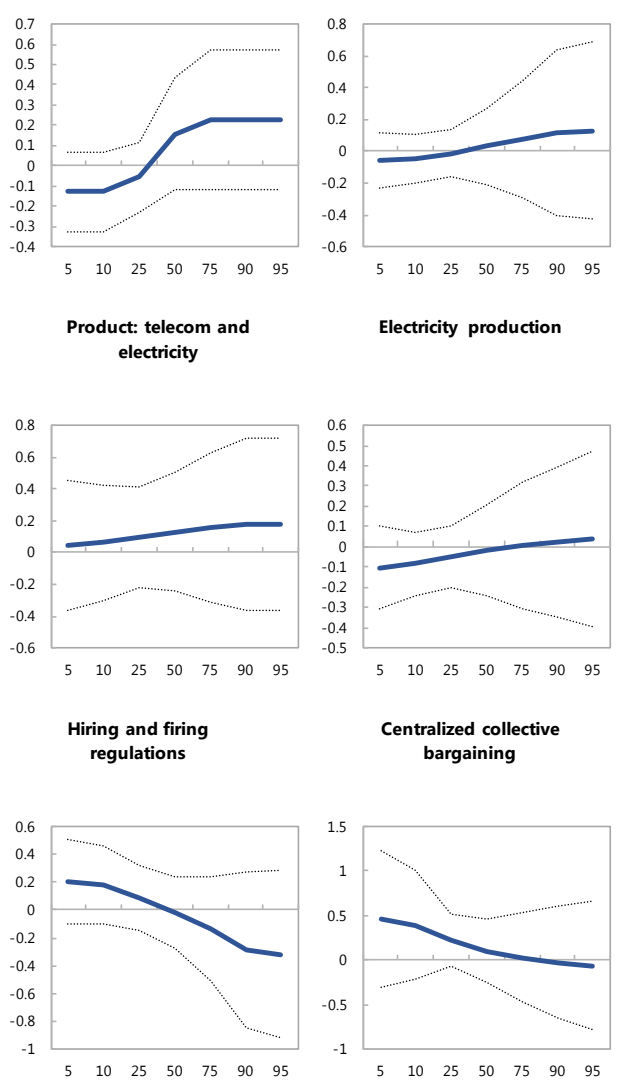

Electricity production bargaining

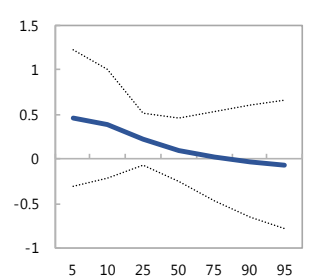

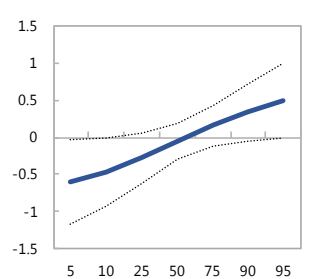

Road density

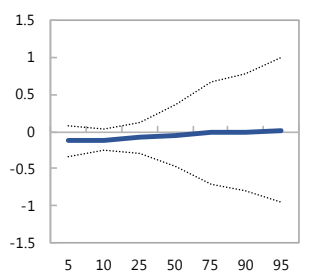

Tertiary education
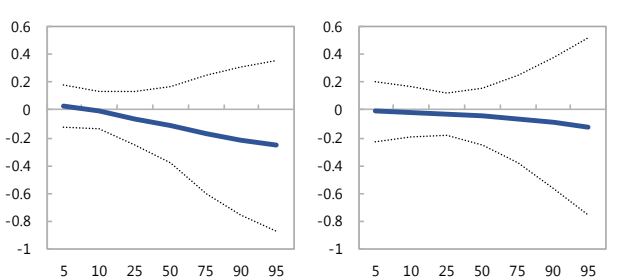

Financial: Privatization
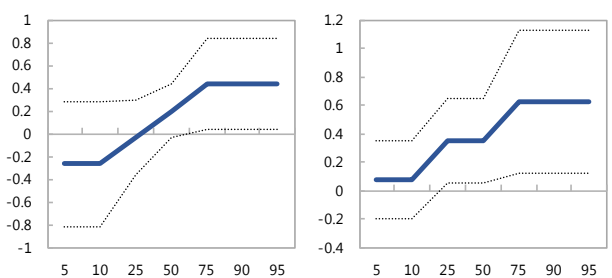

Regulatory trade barriers
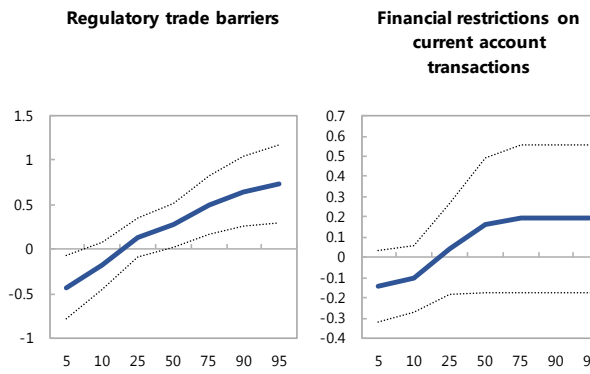

Legal enforcement of contracts

Financial: Banking Supervision

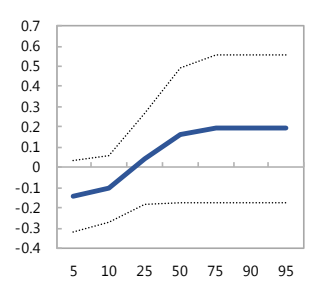

Business regulations

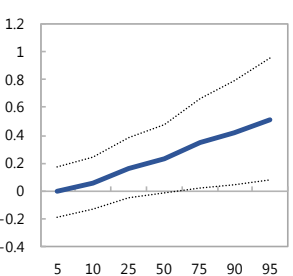

Labor market regulations

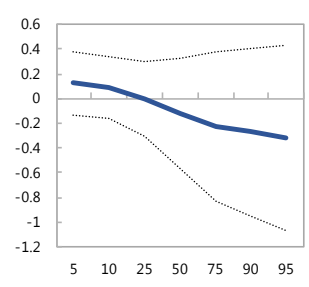

Basic R\&D spending

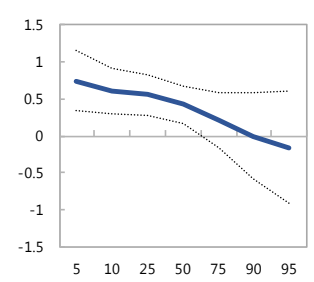

